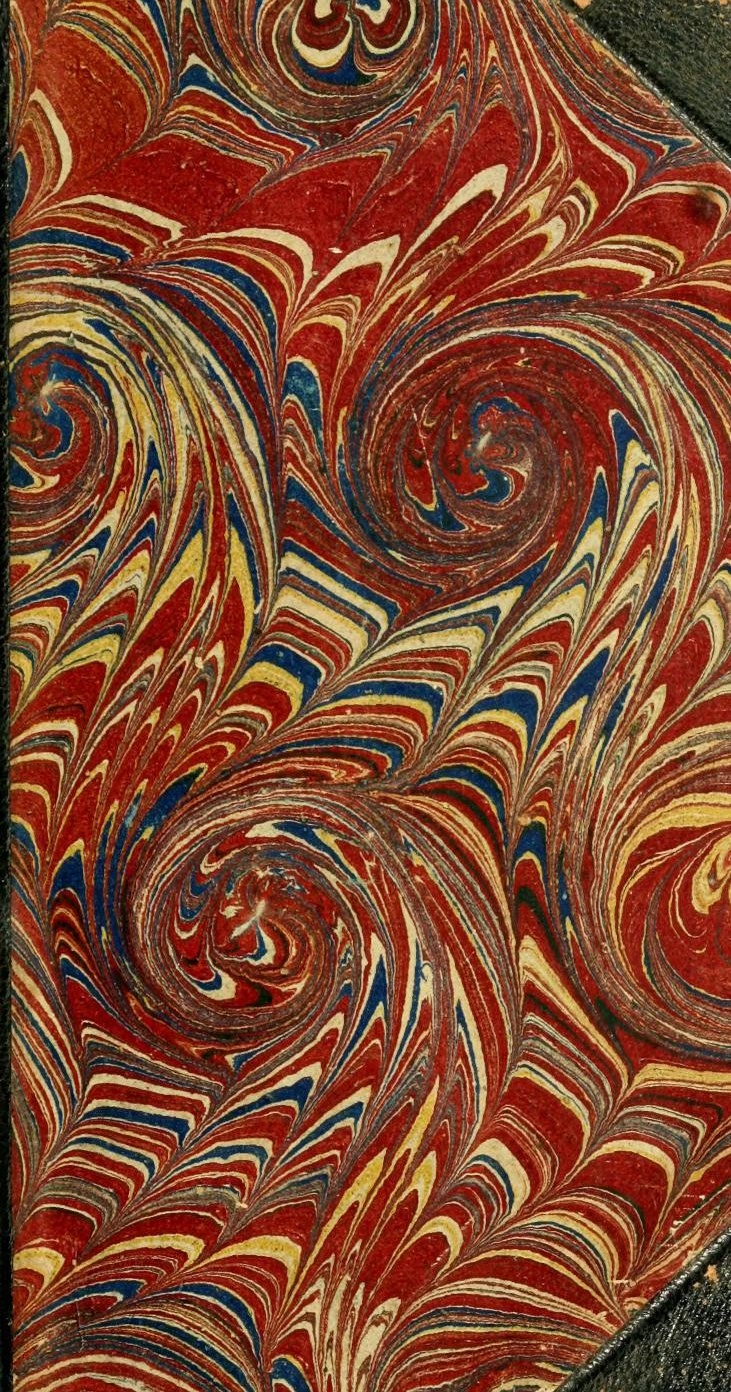












EUROPEAN BEARS. AND PIT.

Published by Marsh and Miller, Oxford-street and Colnaghi Cockspur-street. 
THE

\title{
ZOOLOGICAL KEEPSAKE;
}

\author{
$\mathrm{OR}$, \\ ZOOLOGY,
}

AN1

THE GARDEN AND MUSEUM

OF THE

ZGOLOGICAL SOCIETY,

FOR THE YEAR 1830.

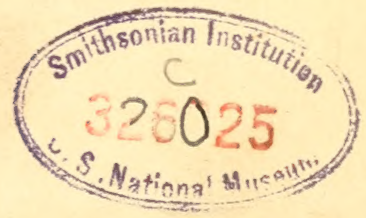

\section{LONDON :}

MARSH AND MILLER,

OXFORD STREET;

AND CONSTABLE AND CO. EDINBURGH. 


\section{LONDON :}

PRINTED BY SAMUEL BENTLEY, Dorset-street, Fleet-street. 


$$
\begin{array}{cc}
590.642 & \text { QL } \\
76.5 \\
1288 & 672.284 z \\
& 1830 \\
& \text { ScDirs }
\end{array}
$$





\section{P R E A C E}

ArThough so wholly original in its plan, the Annual now submitted to the Public demands less, perhaps, of explanatory introduction, than any of those which have hitherto appeared. Where the object is exciusively to ammes, it may be requisite to elaborate the invitation to particular sources of pleasure, since we have, all of us, derived certain unchangeable prejudices on the score of enjoyment; but where instruction is presented to the mind under an agreeable form, we immediately perceive a utility, which appeals to our understanding, and induces our scrutiny.

It is not, howerer, the reasoning faculties alone that aie concerned in the Science which this little work is intended gradually to elucidate for the benefit of the young; the 
heart has a very decided share in the satisfaction with which we contemplate the differing instincts, and the happy recklessness of beings secondary to ourselves in the scale of existence, and is stimulated to fervent acquiescence in the dispensations of Him, whose every creation is so distinctly characterized by an impress of Wisdom.

There are many branches of philosophy which, at a certain period of their progression, cease to be interesting to the majority; but this remark must always be inapplicable to Foology, in which new disclosures of varieties are continually making, and in which the relies of structure, as they are from time to time brought to light, yield to us the most interesting facts and conjectures as to the former state of the habitable globe.

As it will be acknowledged, that perfection in a first effort is usually unattainable in human productions, (howerer studiously it may be kept in view as an object,) the Publishers of this Annual entertain a confident reliance on the candour of those ${ }^{-1}$ ho may patronize it, premising at the same time, that a considerable expancin of tìte 
"There's Mr. Cross, and Mr. Nash,

Are bargaining a few ;

And if the State crmmes down with cash,

Why, we must come down too."

With that they parted from their home,

As for a general rush :-

The Cockatoo put up his comb,

The Fox put up his brush.

The Elephant his trumk prepared,

The Pelican her bag;

And first a sigh or two they spared

And then began to wag.

The morning papers had the news

Of this impcrtant thing;

Some of them rent to the King's MLu's,

'There to amuse the King.

Most to the Regent's Park are fled,

Where little girls and boys

May learn Zoology, instead

Of playing with their toys.

There they are nicely housed and stall'd,

Ther, too, have grot their ology-

Gardens which after them are call'd

The Gardens of Zoology.

The other beasts are lion:s there,

'The Lion is no more ;

The Bear is more than I can bear,

The Tiger is a bore.

Peru's engaging Llama here

You may peruse at leisure ;

And Goats from Cashmere, who for mere

Cash may be had at pleasure.

* The pouch or bag of this bird, in which she car. ries her , ., r. 
The Elephant, who pockets picks, He ought to take a journey, To answer for his naughty tricks Before Sir Richard Birnie.

An Otter, too, who such a smell As you approach discloses, You certainly would never spell The ottar, as of roses.

The Black-tail'd Deer, the Red-tail'd too, And the Rein-deer is here; So many of them meet your view, You'd think it must rain Deer.

The Ouran-Outang drearlful Ape, With his offensive chatter ;

The Satyr, whose half-humian shape Is on mankind a satire.

Monkeys with tricks that nevcr failA curious Kangaroo, Who stands upon the strungest tail, The tale, though strange, is true.

A young Giraffe, whose neck will be Much longer' ere 'tis long, And many other beasts whom we Can't crowd into our song.

In short, whatever folks might trace In Noah's famous ark, (If ever there was such a place,) Are n the Regent's Park.

All things that move on fin or wing, That hop or jump, or crawi,-Ladies and Gentlemen, walk in, And you shall see them all.

* Our readers are probably aware of these amusing little familiarities, with which the Elephant entertains his visitors. 
But if you wish to see them best,

Go at their hour of baiting, For then, to give a greater zest, The keeper keeps them waiting.

They make no licws, they say no grace, They make no bore and bother About precedency and place,

Nor speechify each other.

But with a glorious appetite

That scorns all dinner-pills,

They clear away both left and right, And then-they pay no bills.

When this is llone, we hope you 'll say.

That you have seen enough; We show them firsit the nat'ral way, And then our beasts we stuff:

Nor think these creatures are in vain-

For, without more apology,

The moral I will now explain

That springs from our Zoology.

There's not a beast that roams the field, Or bird that wings the air,

But may a youthiol lesson yield,

When seen in durance there.

The Eagle that would soar on high

In heavenly radiance dipp'dAmbition, here direct your eye, Behold his wings are clipp'd.

Lions that lash, and foam, and tear, But nothing gain by thatLet brawling patrints study here An emblem of their fate.

Here beautenus things of plumage rare Can ne'er be disengaged:

Observe, ye youthful maidens fair, Once caught, you 're closely cagerl. 
Impostors grave may cast their eyes

Upon the solemn owl,

Who is, although he looks so wise,

A very foolish fowl.

Creatures that slowly crawl and creep

In hopes themselves to raise-

Ye Treasury Grubs, look in and peep,

At your own dirty ways.

Here, Dandies, you new tricks may learn, Where Monkeys meet your view; And when you 've seen them-in return, Why let them look at you. 


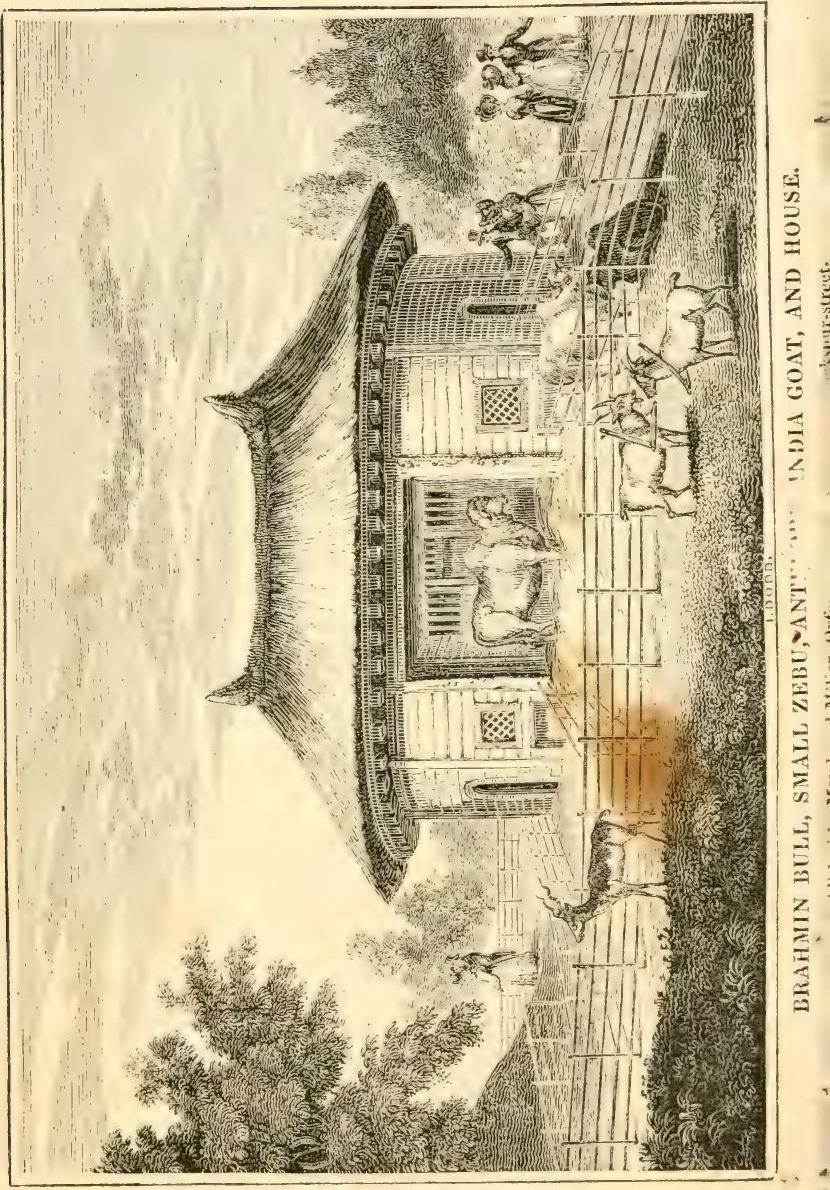




\section{THE}

\section{Foological mengake+}

\section{THE MORNING WALK.}

A TASTE OF PIIYSIOLOGY.-LARLY RISING.-URSAS MAJOR AND MINOR.-TIE NORTH POLE.

EARLY one delicious morning in the summer, Mrs. Aston, accompanied by her eldest daughler, and by her two younger children, Geörge and Jane, entered the Garden of the Zoological Society; and, excepting two or three individuals whom they found there, were the rery first strangers of the day. Miss Aston is almost eighteen; George is eleven; and Jane, eight years of age.

The family resides in the Regent's Park, and is a frequent visitor of the Garden; and all its members usually take advantage of 
the earliest hours at which the gate is opened, not only to enjoy the morning air, and a thousand beauties of the morning landscape, but also because, at that season, the animals are seen to the best advantage; for their several domiciles are then less thronged by company, and they are themselves more lively, refreshed as they have been by sleep, relieved from the fatigues inflicted upon them by gazers, and cheered by the lightness and the brightness of the atmosphere. Our gentle party, too, were in their best spirits at that time of the day. The chimneys of the great metropolis had scarcely begun to smoke; the sun-beams were reflected by the slopes and foliage of the Park, and were gilding its young clumps and groves; the native birds were singing to them as they went, and the cattle lowing in the surrounding pastures; and a few persons, of gentility and distinction, wise like themselves, were enjoying, in the outer circle, upon the northern side of which the Garden is seated, the soft and gay indulgence of a morning ride or walk. Mrs. Aston made it a duty to encourage the early rising of her children; and Jane, 
and even Charlotte, were good scholars in that respect; and though George was the worst of the trio, yet he managed to show his " shining morning face," not "6 unwillingly," and in tolerable time for paying his compliments to the Bears and Monkeys in the Garden, along with his sister's and mamma: a virtue, for the cheerful practice of which, he was also in no small degree indebted for the delight with which he constantly watched the flights and wheelings of the Pigeons; followed the motions of the Ducks and other aquatic fowl; and paused before the sober majesty of the Eagles, and before the sleepy gravity of the Owls !

In reality, while our little company was yet advancing toward the Garden, the blushing tints of the clouds at sun-rise had not yet wholly vanished; and Charlotte felt so strongly the allurements of the scene, and looked with so much pleasure upon the placid and healthful countenance of her sister Jane, that, as she said, she could not help applying, to the charms of their early walk, what a late Swedish poet has said of the Flowers and the Spring :- 
"Victorious Life,

In Light and Song reveals itself once more?

Then, God arouses ye again from sleep,

Sending sweet May to whisper in your ears,

That Spring is blooming in the vaulted heaven,

And that 'tis time for you yourselves to bloom !

Ye then put off your verdant veil, and feel

The Spring-breeze sprealing life upon your cheeks,

Which vie with roses planted by the Morn

Along the garden of the East!"

"Thank you, my dear Charlotte," said Mrs. Aston, "for those very pretty lines :" and Jane, at the same moment, ran to her sister, to testify her pleasure by a kiss. "Well," continued their Mamma, " if you do but carry your good notions into practice, you will be so much the happier, so much the better off, in every possible respect. Could we but truly understand and value the virtues of the morning air, accompanied, too, as in the fields and gardens it always is, with so many sights and sounds to delight the eye and ear, and elevate the spirits, we should certainly resist all the temptations that so commonly lead to its neglect. Putting health and strengtl: entirely out of the question, the mere consideration of good looks should 
weigh with us; for, as Charlotte's poet says of the breezes of spring, so we should say of the atmosphere of the morning,

- Spreading life upon yrour cheeks,

Which vie with roses."

"But, why, Mamma," interrupted George, " should the morning air be better for good looks, than the air at any other time of the day? Surely, noon is beautiful, and so is evening, and so is night! How often you yourself, and sister Charlotte, talk of the beauty of the stars, and especially of the beauty of a moonlight evening !"

"Nature, George, has health and beauty for all seasons; but monning is the renovating and the bracing time, which fits us for the enjoyment of the rest. The great reason is, that the monning air is a bath, and the best of baths, for it goes directly to our blood, and gives vigour to all the springs of life; and of this, the colour in the chceks, and the general goodness of complexion, is an immediate consequence. You will hereafter inform yourself of the particulars; but I will just tell you so much as this, that the air we breathe arrives, in the lungs, in immediate 
contact with our blood; and this, from the form and structure of the lungs, throughout an extent of surface which might seem to you incredible, and which, at the least, far exceeds the whole surface of the exterior of the body. Well, through the circulation of the blood, which is effected by means of the palpitation of the heart, the whole quantity of the blood is estimated to pass through the lungs seventeen times in an hour; and, while passing through the lungs, the blood is chemically purified, or else vitiated, by the atmospheric air which those for the time contain. Now, if it is purified, one of the great consequences is, that it becomes more limpid, and therefore circulates, or flows, more freely; and immediately, therefore, (that is, at its first return to the heart,) it lightens the heart; and the heart, thus lightened, becomes itself more free to act ; drives the blood more freely toward the lungs, the head, and the feet, and from this cause arises all that vivacity, and all that sense of lightness, and that cheerfulness of temper, which we call good health and spirits. But this purifying of the blood, is, among other things, the cooling it; the re- 
moval of all inclination to fever, which is otherwise continually accumulating, and of which the uniform companion is bodily weakness, and depression of spirits. Again, the mechanical cause of a fresh colour (and this, by the way, is literally a cool colour; for I am not speaking of the flush of fever, but of a healthful rosiness,) is the passage of the blood into the rery small ressels which intersect the skin. You are to know, too, that the blood is a compound fluid; or, that, strictly speaking, the fluid itself is white, and that its red colour is produced by the red globules with which it is filled. Now, it depends upon that activity of the heart, which itself, as I have said, depends upon the limpid and other healthful qualitics of the blood, acquired by its communication with cool and invigorating air in the lungs, and also upon the limpidity of the blood itself, whether or not the red globules can be forced, at each beating of the heart, into the fine vessels of the skin, or whether only the white blood, strained of the globules, can find room to enter. But I think that I need not tax myself farther, to rake up the little 
knowledge which I possess, in order to make it appear to you probable, in how great a degree even beauty of person only is promoted by early rising!"

"Oh, Mamma," cricd Jane, (who thought it a very valuable part of the effect of early rising, that they contributed to make little girls look pretty;) "oh, Mamma, I am sure that George must be convinced; but there is one thing which puzzles me. You say, that a fresh colour is a cool colour; and yet a fresh colour is a red colour, and you allow that there is another red colour, which you call the flush of ferer, and which is attended with heat, and not with coolness?"

"The flish of ferer, and the flushes of anger and of shame, depend upon a similar arrival of the red blood in the small vessels of the skin; but the cause, in those cases, is more or less different from what $I$ have now spoken of, as I will tell you another time. But see, the great Bear has discovered us already, and is making his way to the very top of the pole!"

"Mamma," interrupted Jane once more, 
" we might think you were talking of Ursa Major, the Great Bear of the Northern Hemisphere; and of that North Pole which the drunken sailor believed himself to have reached, when he saw, among the Greenlandice, the mast of the wreck of a whale-ship!"

"Very good, Miss Jane," answered her Mamma: "I hope you will remember all your lessons as well as you do this about Ursa Major; and pray look at Ursa Minor, or the Little Bear, which is climbing up the pole so well, and which, you say, is the most good-natured of the party."

"Oh, yes; Ursa Minor knows me, and he knows that I never forget him. I have brought him an apple and his bread !-I will tell George about the drunken sailor as we go home."

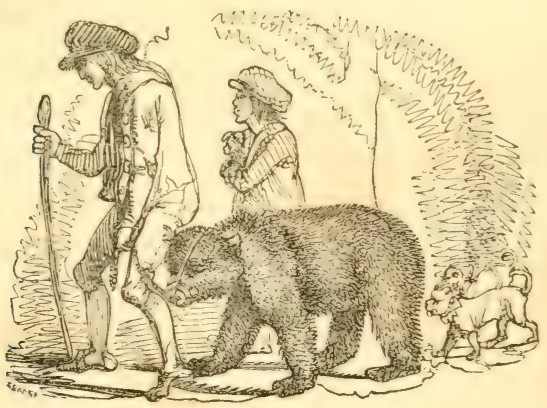


GARDEN OF THE ZOOLOGICAL SOCIETY.

ZOOLOGY.-ZOOLOGICAL.-ZOOLOGICAL GARDEN.-

THE ZOOLOGICAL SOCIETY.

THE respective Bruins, each in their turns, had scarcely received the first attentions of Mrs. Aston's young companions, when Mr. Dartmouth, her brother, who, like themselves, resided in the neighbourhood, and, like themselves, is known to the gate-keepers as an early visitant, ascended from one of the lower walks, and congratulated his sister, and his niece and nephew, upon the fineness of the morning, of which they were making so excellent a use : "Indeed," continued he, "there is nothing here but seems delighted with it. I have been round the Garden once already; and, always excepting the 'things that love night,' every beast and bird secms to be enlivened by the morning sun; and, what with basking in its rays, picking fea- 




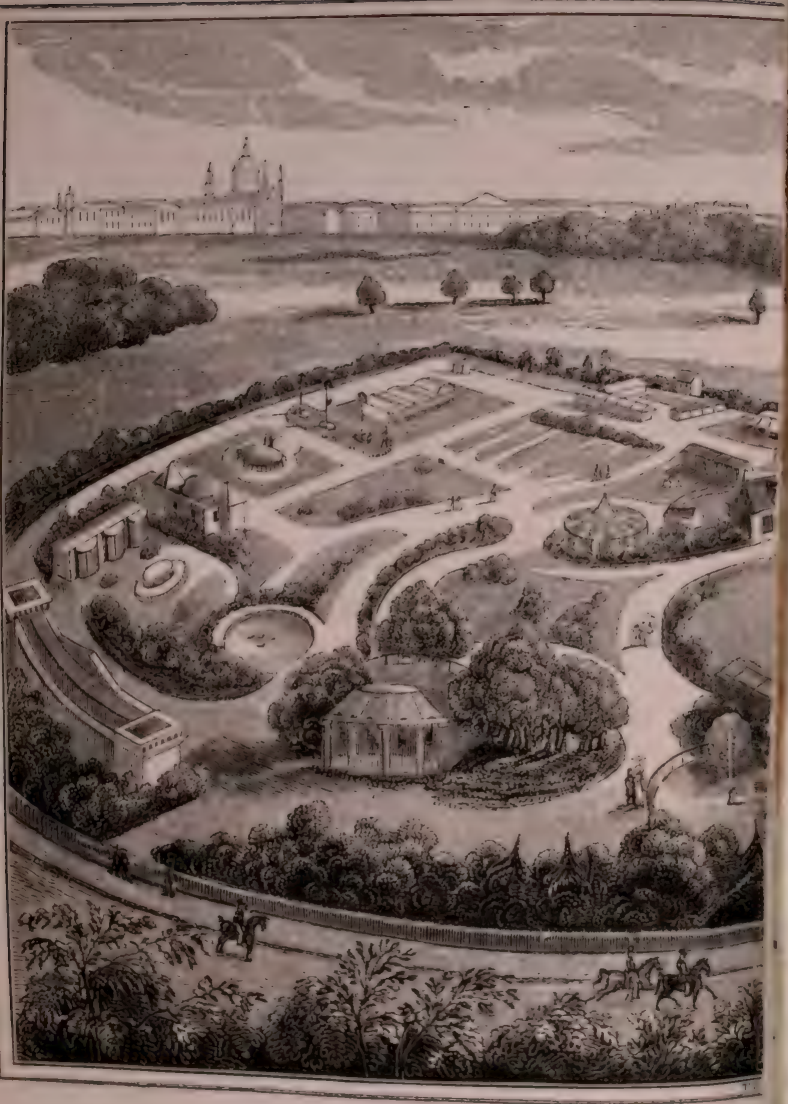

THE GARDENS OF THE ZOOLOG Published by Marsh and Miller, Oxfor

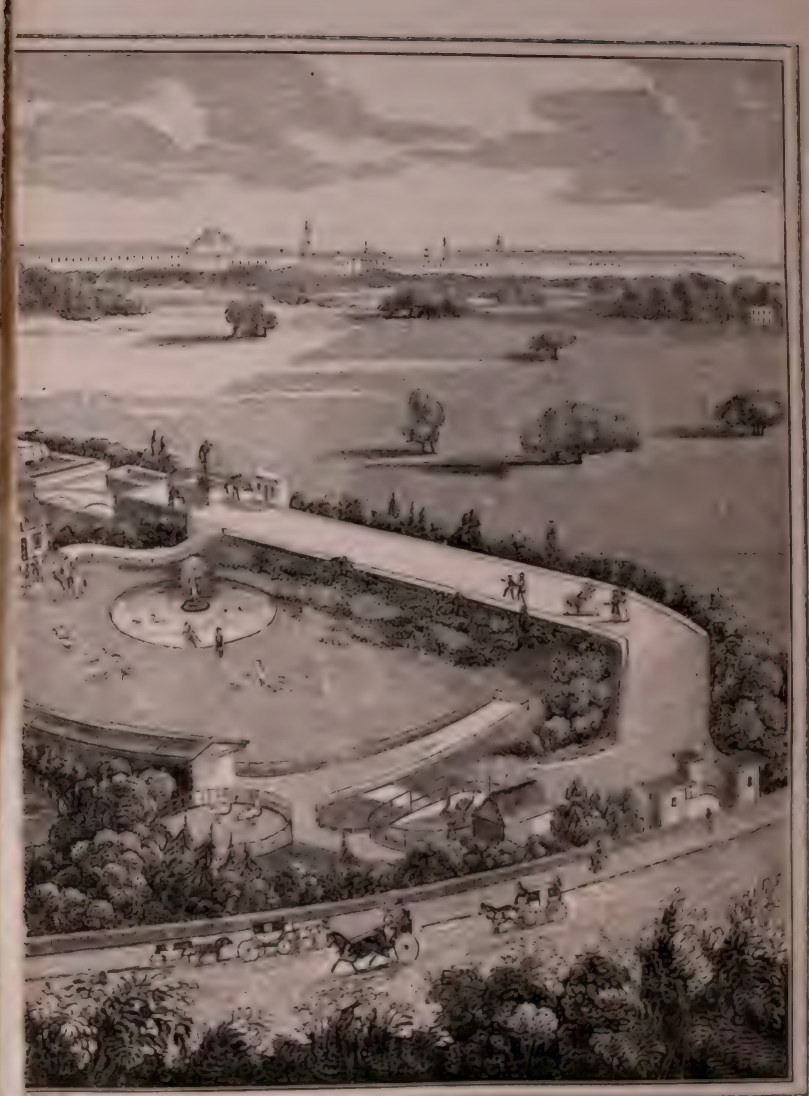

ICAL SOCIETY, REGENT'S PARK.

A-street, and Colnaghl, Cockspur-street. 

thers, dressing the fur-coats, and fluttering and washing in the pools, all unite themselves with the sparkling dew, and the clear skies, to make the picture of nature a picture of happiness and joy. I am so glad that my friend, George, too, is up in such good time this morning, to see the Pigeons that are all alive upon the top of the Llama House, and flying to and fro between that and the roof of the Swiss Chalet !"

"6 Oh, Uncle!" exclaimed George ; "6 you always laugh at me about early-rising; but I was up before Jane this morning, I can tell you !"

"Yes; George was down-stairs one minute and forty-two seconds and a-half before me; and he is so proud of it !"

" And a very laudable pride too," returned Mr. Dartmouth; "6 and one in which, as I hope, he will, always, now indulge. But come, I want to show you the Pelicans. Those unwieldy birds are particularly brisk this morning !"

" My dear Uncle," resumed Miss Jane, (who is a piece of a chatter-box, but a very clever little girl,) "6 you were interrupted, you 
know, the other day, first by the strange noises of the Emoos, and next by the long string of stories about foreign birds and beasts, and whales, and sharks, and great sea-battles, that the old Admiral told us, all the way from the Garden to our house, and which were the prettiest stories that could be;-but you were interrupted, you know, just when you were going to give us a full account of the Garden, how and when it came to be planted, who planted it, and why it is called Zoological? Our maid, Susan, says she is sure Zulogical (as she calls it) is some kind of tree that grows here, as mangelwurzel grows in the Park; and that a Zulogical Garden must be full of Zulogicals, as flower-gardens are full of flowers! Only think, Uncle, how silly Susan is!"

"Not silly, my dear, but uninformed. Susan has not been so lucky as you, in being told the meaning of such a fine word as this ZO-O-LOGICAL, of which, as I suspect, three-fourths, at the least, of all the good people in town and country, knew neither the meaning nor the pronunciation, some three or four years ago!" 
"What, Uncle," cried Janc, "was the word Zoological made only three or four years ago? Why, la! I am twice as old as zoological. Who would have thought it!"

"Not twice as old as Zoological, little Jane; but, at least, twice as old as the familiarity of any part of the English public, and especially of the London, with the use and meaning of the term. People could always talk about Natural History, and about the History of Animals, but they did not know the ' Science of Animals,' or the 'Science or Knowledge of Animated Nature,' by the fine name of Zoology, a term compounded from the Greek.

"6 Oh, "Zoology' is Greek !" cried George ; "' and, now, I remember that 'w̃ov is the Greek word for ' an animal :' but what is the meaning of $\log y$ ?"

" In strictness," said Mr. Dartmouth,

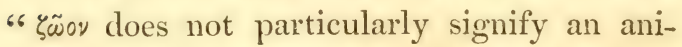
mal, nor even a living being, but a being of any kind whatever. But, in this instance at least, the word is received as signifying an animal ; and logy, or logia, is from the Greek royos, a 'word,' 'speech, 'or 'discourse.' Now, 
words, speech, or discourse, are the medium of communication for knowlege or science; wherefore the word 'Zoology' signifies the Science or Knowledge of Animals, or of Animated Nature."

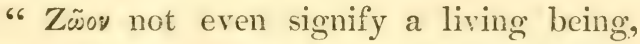
Uncle, in particular!" exclaimed George;

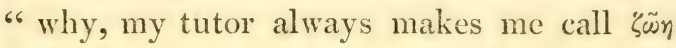
"life." "

" Scholars will commonly tell you, George,


' an animal being;' but this is only the ignorance of scholars. Sometimes, too, they very seriously ill use their mis-interpretation of the word. Z Zov signifies any being whatever; and we must give both substantive and adjective, before we can make out, either animal being, or even living being, such as we usually understand it in this phrase. It is true, that

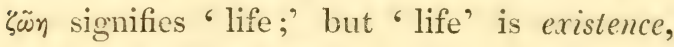
and every thing exists."

"Does not Linnæus, Sir," inquired Miss Aston, " carry up the climax of existence thus:- 'Stones grow; plants grow and live; animals grow, live, and feel?" "

"Yes, my dear, he does; and we all know 
the limited sense in which we commonly speak of life. Animals are beings, lixing beings, and sentient, or conscious, or feeling beings ; but all being is life; all life is existence; and eren stones, in that comprehensive use of the term, live, because they exist. Howerer, though it is essential to all accurate knowledge, and to all soundness of thinking, that we should have precise notions of the original and strict meaning of words, we must often be content with their accepted meanings; for, without these, there could be no language sufficiently full for the expression of our ideas. Words, when traced to their roots and substantial forms, are rery few in number; and we are enabled to express oursulves only by giving to each, upon this or upon that occasion, a great variety of capricious forms, and of arbitrary meanings."

All the young persons had sufficient cducation and understanding to be instructed by their Uncle's remarks; and Mrs. Aston thanked her brother for this additional example of the efforts which he often made to accomplish them, not so much in the possession of clear ideas upon particular subjects- 
for of them, of course, his opportunities could apply but to a very small proportion; but in that great and comprehensive art, the habit of forming clear ideas for themselves: "The opposite habit," he would often say;-“" the habit of contenting ourselves with only obscure and confused ideas, is the greatest foe to knowledge; - the source of infinite ignorance; - the source, therefore, of infinite mischief!"

"Well, my dears," resumed he upon the present occasion, "we have now got so far as to understand, that the word Zoology signifies the Science or Knowledge of Animals, or of Animal Being, or of Animated Nature. It follows, that by the term Zoological, we mean whatever belongs to Zoology; and next comes the question, not of the Zoological Garden, but of the Zoological Society."

"Not of the Zoological Garden, Uncle?" interrupted Jane.

"The term, Zoological Garden or Gardens," replied Mr. Dartmouth, " is very convenient, and, as such, is employed, I observe, on the head of the pages of that beautiful 
and intelligent work, entitled, 'The Gardens and Menagerics of the Zoological Society,' and which is stated to be 'Published with the sanction of the Council, and under the superintendence of the Secretary and Vice-Secretary of the Society ;'-but you will observe that, every way with more accuracy, the name of the place in which we are, as described upon the title-page of the 'List' which you have obtained at the gate, and which is now in your hand, is, not ' Zoological Gardens,' but 'the Garden [not the Gardens] of the Zoological Society."”

"And yet there seems no objection, brother," said Mrs. Aston, " to the term " Zoological Museum?" "

"None at all, my dear," replied Mr. Dartmouth; "for the Museum is a Zoological Collection or Repository ; and it is only because, like Susan, we think of Gardens as places wherein something is groun, that the term Zoological Gardens is apt to be understood, and should, in strictness, mean, a place in which Zoology is grown! In the abstract, however, a garden is simply an enclosure, or, as we otherwise say, a park; and, with that 
understanding, there would be nothing wrong or equivocal, and therefore misleading, in the term 'Zoological Garden.' In truth, we are in a park or enclosure, formed, within the Regent's Park or Enclosure, for Zoological purposes; and therefore a Zoological Park, Enclosure, or Garden. The word ' garden' implies that which is ' girden,' 'girded,' 'garded,' or 'guarded,' or is within a fence, girth, garth, or girdle. In the north of England, a garth signifies an 'enclosure ;' and another form of the same word is 'yard.' A yard, court-yard, and the rest, imply enclosures, and literally, gardens. In the woods of North America, the space which an Elk (Moose) hollows and beats smooth for himself and family in the midst of the snow, is called a 'Moose-yard.' But, in reality, this Garden seems to have obtained the name of Zoological Garden, only in servile imitation of the 'Jardin des Plantes' at Paris. We are often guilty of this sort of servile, because inappropriate, imitation of our neighbours, in France as well as those elsewhere!"

"The imitation," observed Mrs. Aston, 
" is, perhaps, not to be wondered at, because the Jardin des Plantes actually contains a Zoological Collection, and because there is no doubt that the whole scheme of the Zoological Society, at least as far as the placing its animals in a garden, is founded, not so much in imitation, as in laudable emulation, of the Jardin des Plantes."

" I es," returned Mr. Dartmouth; "but the difference is this, that the Jardin des Plantes is essentially a Garden, in the ordinary sense of the term; that is, a Garden for the scientific cultivation of plants; a Botanic Garden, into which a Zoological collection is farther, and as it were incidentally, introduced; while our Zoological Garden is in no respect a botanical, but simply a Zoological enclosure ; an ornamented park, in which animals are kept. The trees, the herbs, and the flowers, which we see here, like the fashion of the buildings, are simply ornamental, and no part of the essence of the design."

" Perhaps equal criticism," resumed Mrs. Aston, "6 might be offered, brother, upon the name of Horticultural Gardens-the name by 
which we know that pleasant place at Chiswick, to which all the world goes annually, to be wetted to the skin!"

"Undoubtedly ; for, in propriety, they are not the Horticultural Gardens, but the Gardens of the Horticultural Society."

"Horticulture means ' gardening,' does it not, Mamma? So that it is droll to talk of gardening gardens !"

"Yes, my love; horticulture means 'gardening,' or the cultivation of gardens; as agriculture, in its turn, means the culture or cultivation of fields."

"Is there not a foolish word at present in fashion," inquired Miss Aston; "I mean, the word agriculturist, to signify, sometimes a farmer, and sometimes a farming-man?"

"Yes, my love," answered Mr. Dartmouth; " and there was a time," he added, "when we called farming husbaindry, a farmer a husbandman, and his labourer a labourer only, or a labourer in husbandry. But we threaten to change all this. We are to call our manufacturing work-people operatives, and our farming-labourers, agriculturists. The latter denomination is particularly absurd, because 
we want it elsewhere, to distinguish that very distinct class of persons, with which agriculture is a science! We may observe, by the way, that our good old word, husbandman, is of Saxon derivation; and that of farmer, (fermier,) Norman."

"We have many other names and phrases, I believe," continued Miss Aston, "that are literally indefensible?"

" Yes; and none more so, I repeat, than those in which we servilely and ignorantly take up something that is French! There is not, from one end of the kingdom to the other, a combination of words more illiterate than those which occur in this title, - ${ }^{6}$ The Royal Society of Literature!' What should we have said, if the Zoological Society had called itself a Society of Zoology ; the Geological Society, a Society of Geology ; a Botanical Society, a Society of Botany, or even a Society of Plants, Vegetables, or Potatoes ; or, if the Society of Antiquaries were called a Society of Antiquities, or of Antiquity ; or, even if the poor Mechanic Institutes had blazoned themselres, Societies of Mechanism?" 
" And yet, the Royal Society of Literature," said Mrs. Aston, "is an ambitious society, I believe, and has distinguished members?"

"Yes; but those things have nothing necessarily to do with real knowledge, and especially with pure English! The plans and other documents of the Society contain many terms and phrases as illiterate as its denomination. But the source of the capital blunder is, that the whole scheme (pitiable in all its parts!) was originally conceived upon the model of the French Academy; and that the borrowed plume is not known how to be put on! A 'Royal Academy of Literature" (however detestable in itself) would bear an intelligible title, like that of the 'Royal Academy of Painting and Sculpture,' of which the apartments are at Somerset Place; but the phrase, 'a Royal Society of Literature,' is sheer nonsense, as must be obvious; and so contemptibly illiterate also, that it would have disgraced a parish meeting, either in Cumberland or Cornwall!"

"Our best scholars, I think," said Miss 
Aston, " are not always remarked for their good English ?"

"By no means," answered Mr. Dartmouth.

"But Papa says," cried Gcorge, "that the worst of all is, the illiterate name which, since the union with Ireland, has been given, by authority, to this kingdom! TWhat can be greater nonsense than the phrase, the United Kingdom? The United States, and the United Provinces, the hapless models, (Papa says,) of so much modem English ignorance, are really English phrases; that is, they are grammar. But how can a single state, province, kingdom, or territory, be a ' united kingdom,' or the rest? We may say, poetically, that a kingdom (that is, the people of a kingdom-a multitude of individuals) are, or is, 'united;' but how can a single territory be a subject of union? How can it be said, that the King' is ' King of the United Kingdom,' unless, indeed, we mear, (what we do not mean!) the united people of a kingdom; for we mean united territories, that is, united teritory!" 
"I agree with your Papa," said Creorge's uncle; "and I wish the opportunity had not been lost, for calling our King, in English as in Latin, ' King of the Two Britains.' In Latin, you know, George, and as you see upon the coin, the King is called, simply and classically, "Rex Brittaniarum." "

"Ah! that puts me in mind of the ' King of the Two Sicilies ;' and I am often puzzled to know why the King of Naples, commonly so called, has the more formal title of King of the Two Sicilies? I know of but one Sicily?"

"You mean the island; but the other Sicily is the adjacent dominion upon the continent of Italy; the dominion of which $\mathrm{Na}$ ples is the more immediate capital. I confess, that $I$ borrow the thought of the ' King of the Two Britains' from that of the 'King of the Two Sicilies;' and I reckon upon many advantages from so calling the sovereign of this realm. I do not mean that Ireland was ever yet called one of the Britains, but I think that the name Great Britain is only a duplification of the word 'Britain,' which, in itself, I suspect to mean Great, or 'Broud Land,' or 'Island;' and this, either 
absolutely, or in reference to those smaller islands, Ireland, the Scilly Islands, Orkneys, and the rest, which contribute to the formation of the British cluster or archipelago. I am reminded of this by the Two Sicilies themselves; for, with reference to the island of Sicily, the adjacent part of the Continent was anciently called Broad Italy; as was also Continental Denmark, in contradistinction to the Danish Islands, Broad Demmark. But Broad is another word for Great; and I believe that Magna Brittania signifies ' Broad Britain ;' and that, more anciently, and before the meaning of the primitive term was overlooked, the word Britain itself signified neither more nor less than the Great or Broad Land, or Island. I must acknowledge, too, that, besides valuing the title I propose, as comnected with philology and history, I should consider it as ministering to that moral mion of the Two Brilains, which is so highly to be desired, and which seems so difficult to be attained. If Ireland were called West Britain, and Great Britain, East Britain; then, the sisterhood, or the brotherlood, of the two islands would be familiar- 
ized to the tongue, and, through the tongue, familiarized also to the mind !"

Our party wound up their discourse with this decision, that the term Garden of the Zoological Society is too lengthened, and too formal, to be always conveniently employed; and that, if we could but bring ourselves to think of a garden as no more than a space of ground which is girden, garden, or enclosed, there would not remain even a literal objection to the term, "Zoological Garden." Young persons are great critics, and exceedingly acute in the discovery of weak points, both in argument and in modes of expression. Equally in language as in life, they are zealous for the abstract right, and commonly less disposed, than their elders, to admit or to tolerate qualifications, exceptions, or allowances; and, in a more proper place, something might be added, as to the causes, and as to the good and the evil, of these differences of temper, in the younger and the older, and on the happy medium which, alone, and upon all occasions, is to be commended, both in the older and the ycunger !

The family being habitual visitors of the 
Garden, they did not scrupulously derote the whole of their time in it to Zoological sights or dialogues; and though, in general, we shall omit to follow their example, and, for our own parts, dwell upon little that is not Zoological, yet it may have been acceptable to preserve the foregoing points of information, interesting as the particular topics must be to young English minds, eager for knowledge in general, and especially for such knowledge as regards the history, and as affects the honour, of their beloved native country! We are presently to advert to the conversation of the following day, when Mr. Dartmouth spoke of the whole plan, and public ormament and utility of the Zoological Society; and of the interesting and instructive biography of Sir Thomas Stamford Raffles, the chief and most zealous instrument of its foundation.

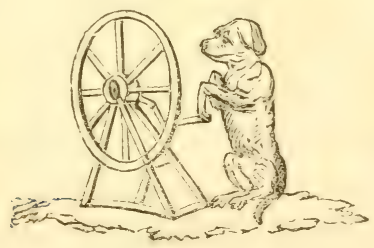




\section{THE ZOOLOGICAL SOCIETY.}

TRIMROSE HILL. - THE REGENT'S PARK.-REGENT STREET.-MR. NASH.-THE ZOOLOGICAL SOCIETY.SIR THOMAS STAMFORD RAFFLES.

As Mrs. Aston walked, with her children, the next morning, to make another visit to the Garden, she remarked upon the beauty of the risiug plantation which, to the northward of the soad, conceals the canal, and with the canal, the adjacent fields and hills.

"I wish, very much," continued she, that Primrose Hill were taken into the Park. It would be a shame to let it be covered with houses, as is now daily threatened; and besides, I have a plan for making the Hill, and all the interrening ground, a better place for popular enjoyment, than, as I think, the Park, already so called, is ever likely to become. I greatly approve of the fences which now surround the pastures and young 
trecs; and I doubt exceedingly whether they ought ever to be removed. The soil is a clay, and, therefore, in wet weather, all the grass would be very unfit for walking upon; and the more the trees shall grow, the less safe, as it seems to me, will it becone, to throw open such a place to all the idle, and all the disorderly, of a great metropolis. We hear of the difficulty with which Kensington Gardens, and the older Parks, are kept secure under these aspects; and, to say nothing of the thefts, and of the mischicf to the place, I greatly fear, that the Regent's Park, once fully opened, would need a very numerous police! But I would enclose Primrose Hill, as also the ground between it's foot and the canal, upon a plan less nice, both as to decoration and restraint. Anything would be an improvement upon their present condition, and with that, so far, I would be content. The great point to be attained is, to secure the hill and the fields for the enjoyment of the metropolis for ever; and next, to make them substantially ornamental. Once secured, I would decorate the summit of the hill with a plantation, which 
30 HEIGHT AND CLOTHING OF HILLS.

here and there, should descend toward its base; for the outline of a naked hill, and especially of a green hill, bounded by the sky, is never a pleasing, and always an unnatural object, since Nature uniformly clothes with trees all the heights that are capable of growing them, as well as all the declivities and plains, even into the shallows of its lakes and rivers. Again, the growing of trees upon Primrose Hill would add considerably to the appearance of its height; and this, therefore, would be consulting the picturesque and beauty of the landscape. As to the greensward and surface, I should, perhaps, do very little; but a main feature of my plan would be, to reverse the order of enclosure in this new part of the Park, as contrasted with the other. Here, I would enclose only the plantation, and leave all the grass at liberty. The communication between the respective parts would be by means of one or more bridges across the canal; either new bridges, or those already built; and, in the new, or northern part, I would trace one car.riage-road, making a circuit of the whole, and giving the benefit of the high ground to 
the sitters in carriages, and riders upon horses; and then leave all the rest, with little solicitude, in full possession to the multitude at large. I cannot but think that the execution of this project of mine is absolutely wanting to the completeness of that beautiful and beneficial work, the conception and performance of which reflect such distinguished honour upon the name and genius of Mr. Nash!"

"Who can tell, Mamma," cried George, enraptured with the scheme, " but that what you say may yet be done; for, you know, Papa planned the opening of Pall Mall, by removing Carlton House, long before it was talked of in public! Papa said, that the view of St. James's Park was the only proper finish to Regent Street, of which the line begins in the Regent's Park; that the situation of Carlton House, after the hill of the County Fire Office had been opened to view, appeared low and degraded; and (what is not yet accomplished) that it would be desirable to open a horse and carriage-way through the St. James's Park, under similar restrictions, perhaps, with those at the other gates, so as to relieve Charing Cross of a great part of its 
traffic to and from the Horse Guards, the Treasury, the Courts of Law, and the Houses of Lords and Commons. Now, as so much, of what Papa imagined and talked of, is already done, I see, that though private people have often no means of carrying their plans into effect, and even of making them known, still they may be as good and as practicable as those of others!"

"Well done, George," said Jane; "and when Primrose Hill is enclosed, all beyond the bridges shall be called, not the Regent's Park, but dear Mamma's!"

George and Jane had run many times round the Garden, and Mrs. and Miss Aston had paid long visits to the Paca and Guanaco, and to the Beaver House, and to the Emoos, before Mr. Dartmouth joined the company; but after his arrival, he was soon called upon to fulfil his promise of giving explanations of the Zoological Society's plans, and of the history of Sir Stamford Raffles, whose name so frequently, and so deservedly, occurs in the catalogues, and upon the labels, throughout the Garden and Museum.

"There are three objects to be attained," 
said Mr. Dartmouth, "by that study of the animal creation, to the whole circle of which the labours and collections of the Zoological Society are devoted. The first is, the pleasing and innocent recreation which is afforded us by the simple view of so many forms of beauty and marvellous structure and adaptation, and the endless displays of movements, habits, and manners which it comprises; the second, the various advantages which, from time to time, and from instance to instance, we are capable of deriving from the several species, either for our necessities, or for our pleasures, and which it is reasonable to expect to multiply, in proportion as our acquaintance with the animal world is enlarged; and the third, the continual incitements with which the study is filled, to admire from day to day, and daily to admire more and more, the wisdom, the goodness, and the power, which is and has been displayed in their production; the continual appeal which it proffers to our most holy meditations, upon that infinity of form, and of utility, beauty, and happiness, in which consists the animal creation, from its highest 
rank to its lowest. In all the other parts of the visible universe, as in that of which we are now speaking, we behold form and beauty the most ample, the most impressive, and the most ravishing; but, in the animal, we have the superaddition of moral and of intellectual charms; we see creatures, not only beautiful but happy, and not only happy, but gentle, tender, compassionate, sympathising, and benevolent, or at least innocent, like the best, and like the fairest, among ourselves; creatures reflecting back again, as it were, from earth to the uplifted skies, that love and that goodness which gives and which sustains their being; and creatures displaying, too, that intellect, that wisdom, that ingenuity, which are the best types of the infinite wisdom, the almighty understanding, which ordained and which organized their being; and all this, accompanied by those manners-those movements of animated bodies-either sedate or sportive, either expressing gaiety, or tranquil enjoyment,and proclaiming thus the beneficence of the giver, and winning from our sympathies, and from our testimony to the sweetness, the great- 
ness, and the glory of his works, fresh praises of his name, fresh homage to his nature; fresh remembrances of all that we owe to him, of all for which we adore him, and of all that which, by his audible command, and by a natural, a generous, and a worthy imitation, it is our own duty to perform, to him, to ourselves, and to our fellow-creatures;to our fellow-creatures of all ranks, from the Emmet to the Man!

"6 The collective views that I have mentioned unite themselves in the schene of the Zoological Society; and, whether we look at the tendency of its institution to increase our enjoyments, or our knowledge, or our virtue, it is obviously a work of patriotism,-a tribute to the happiness of the country. It is a work of patriotism, too, under an aspect separate from those of which I have spoken. The Garden and the Muscum are embellishments of the metropolis,-embellishments of the entire kingdom. They offer one of the most innocent, one of the most elegant, one of the most instructive of the public recreations; they afford to thousands, and to hundreds of 
thousands, moments, and hours, and days, of little excursions of cheerfulness and pleasure, and which, at the same time, promote the health, and enlarge the ideas and the reflexions of the people. They gratify the residents and visitors of the metropolis, and their fame is extended through all the country. Now, whatever adorns or ennobles a city or a country, promotes the love of that country or city, impresses the imagination, enchains the memory, presents an object to be recollected, and to be loved; and the beautiful buildings, parks, gardens, statues, and pictures, to be found, either in a city or in a country, are so many links of memory and of attachment. In the scenery of $\mathrm{Na}$ ture, forests, rivers, mountains, and lakes, as well as trees, herbs, flowers, and all the softer features of the landscape, appeal to the senses of the spectator, and bespeak his love for the spot in which they are seen; and bind themselves in his memory, and perpetuate his regard. But it is equally so with the works of human labour, industry and genius. We love our country, as we love every thing else, for all that it contains of beautiful, for all that it 
affords of pleasing, for all that memory records as having pleased us. I must speak upon the point with brevity ; but it is certain that whoever embellishes, whoever enriches, whoever ennobles his city or his country; whoever adds to its bodily, or its intellectual charms; cncourages and warms its love, incites the patriotism of its people, and invigorates the sentiment that is its happiness, its glory, and its strength. It is with Art, then, as it is with Nature; and you recollect what is said of the beauty of $\mathrm{Na}$ ture, among the pretty lines of Langhorne:

\section{' Not in vain!}

I hear my Hamrton reply,

(The torch of Fancy in his eye :)

'Tis not in vain, I hear him say,

That Nature paints her works so gay;

If sweet sensations tirese produce,

I know they have their moral use;

I know that Nature's charms can move

The springs that work to Nature's love!"

"6 All visitors must have orders, I believe, from Members?"

"Yes; or else Members must personally introduce them. Or, Members are enabled 
to procure ivory tickets, upon paying a guinea annually for each, which will always admit one person named, with a companion. Members may always take two persons with them, either to the Garden or Museum; but, if a greatcr number, they pay a shilling for each ; and a Member's privilege may be transferred from himself to any individual of his family whom he may name to the Council. It is to be added, that the Garden is opened to Members at eight o'clock in the morning, but to Strangers, not till ten."

"The necessity that Strangers must either be introduced by Members, or else provided with their orders, or with their tickets, is productive, I should think, of some inconveniencies?"

"It certainly is so ; but, upon the whole, the restriction is probably beneficial. Besides, few of the persons who are proper visitors, can have much difficulty in finding Members willing to oblige them." *

* Through the kindness of Members of the Society, Messrs. Marsh and Miller, the publishers of the Zoological Keepsake, 137, Oxford-street, are frequently enabled to accommodate their friends with Orders both for Museum and Garden. 
" It is evidently proper, that in the admission of Strangers, some degree of system should be observed, especially at the Garden, for the sake, both of preventing mischief and injury to the Animals, and to the Garden itself, and of contributing, in some degree, to save the visitors themselves fiom the accidents that sometimes attend exhibitions of wild beasts of prey. The rulgar are too fond of irritating the fiercer animals, and of teazing and hurting those which are gentle; and both vulgar and others are often exceedingly rash, in introducing their hands into the dens and enclosures, or careless in placing themselves so near the bars, as to defeat the effect of every precaution for their safety. Upon the first subject, as you know, we have had to caution George; and I believe both George and Jane are indebted to some risks which they have run for the respectful distance which they now keep. Only the other day, too, as we saw, one of the Wolves, though so well guarded in the kennel, bit the arm of a little boy that had taken much pains to introduce it through the bars. You see, therefore, that caution is needful; and, perhaps, even in this view 
alone, it is proper that the admission should not be indiscriminate. The necessity for orders almost prevents young people from coming without some superintendence.

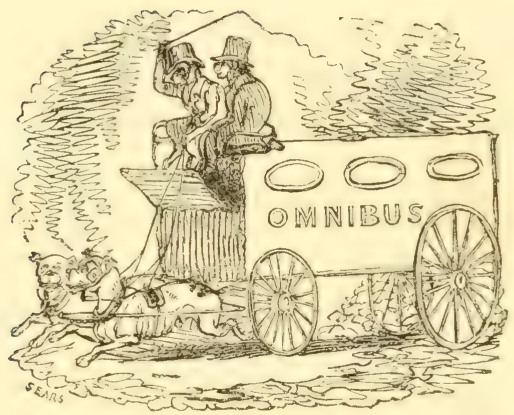




\section{ORIGINAL POETRY.}

\section{THE DEAD CHARGER.}

BY H. J. BRADFIELD, ESQ.

Tre shades of night hung o'er the plain,

In darkest hues afar;

Where 'mid the dying and the slain,

Upon the field of war,

Many a Courser lay beneath

The Hero, in the pangs of death.

At break of morn his heart beat high,

When the shrill war-note sounded; And proudly flash'd his beaming eye,

As to the fight he bounded,

And, like his warrior-rider darted

Glance for glance, till life departed.

Banner's with crimson gore are wet, And swords are lying there to rust; While Death his chilly hand hath set

On many a brow now turn'd to dust ! And Hope whose ray around was shed, With the undaunted spirit fled. 
Faithful to his lord's high will,

He sought the foe with eager breath; And scorn'd th' artillery's fire, until Pierced by the shaft of death! Then found he with his lord a grave, Where fiercely fought and fell the brave. 



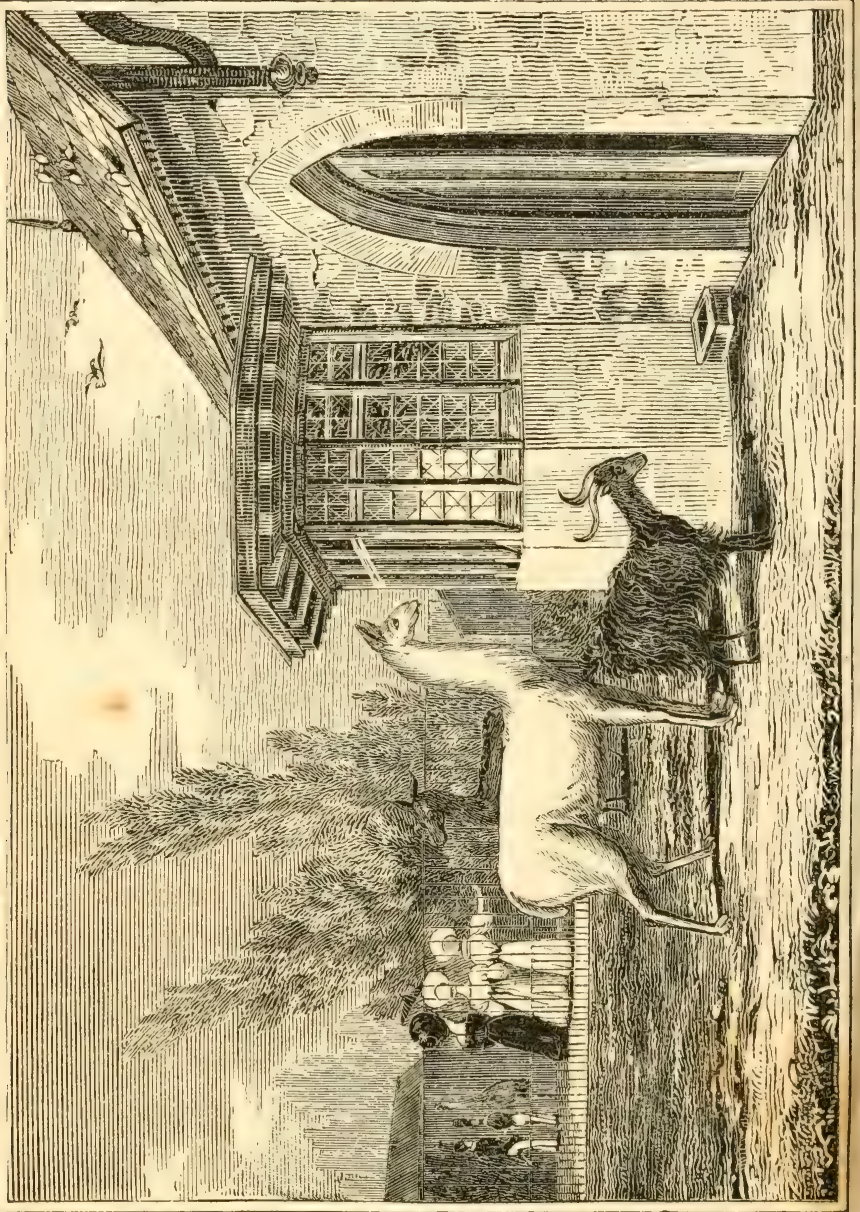




\section{LLAMA-HOUSE.}

Which is tire Llama? - South American Camels. -Vigonia. - Guanaco. - Llana. - Cashmere black Goat.

THE next day, when Miss Aston was about to ask some further explanations of her Uncle, the party was joined by their friend, the Admiral; and as the Gallant Officer, in the course of his long service, had happened to see something of South America, and to make himself more accurately acquainted, than many others, with all that is peculiar to that country, he was fond of leading those with whom he conversed in the Garden, to what is called the Gothic House for Llamas, where he pointed out the peculiarities, and explained the natural history, as well of the Llama itself, as of the animals with which it is so usually confounded. 
"You are mistaken, my dears," said he, upon the present occasion, "when you follow the common speech, and common natural histories, and even the 'List' given you here, in calling both those animals ' Llamas,' and talk, as every body is talking, of the 'Brown Llama,' and the 'White.' There is but one 'Llama' in this Garden, and I shall ask you, presently, to show it to me.

"I am afraid, Admiral," replied Miss Aston, "that we must owe all our knowledge to your kindness; though we certainly have read so much as to lead us to suspect that one of them is a 'beast of burthen,' and the other not; and that one is properly called the 'Llama,' and the other by a different name."

"Well, then," said the veteran voyager and sailor, "let some of us set ourselves down upon this bench, opposite my old acquaintances, the Maccaws, while I try to put the matter a little plainly for your information. Previously, however, I must so far qualify what I have said of the prevailing ignorance of our Zoologists, as to remark, that I refer exclusively to their nomencla- 
tures, and to their classifications, and by no means to animal physiology, in which branch of the science Sir Fverard Home and others have made brilliant progress. While making concessions, too, let me not forget to pay my humble meed of tribute to the labours of my friend, Joshua Brookes, who did so much, so long ago, for advancing the sciences of anatomy and physiology in general; and, among the rest, for Zoological anatomy and physiology !"

The party here proclaimed their thanks for the obliging task which the well-informed and hearty Admiral had taken upon himself, after which the latter proceeded to commence his observations.

"There are three, and only three, descriptions of animals, in Gouth America," said he, " which the Spanish settlers have brought to our knowledge, under the name of 'Peruvian Sheep;' and which Zoologists have long since resolved into three descriptions of Camel.* Amid the confusion of the

* Critical accounts of the South American Camels, by the Editor of these pages, appeared, with coloured figures, in the Colonial Journal for 1817 and 1818. 
accounts given, however, as well by writers as by travellers, the three animals have often been multiplied into five; and, among the three Sheep, or the three Camels, there has even been found a Horse. Molina, the historian of Chili, and Shaw, in his System of Zoology, have a Chili cloven-footed Horse! But in this manner has much of all $\mathbb{Z}$ oo$\operatorname{logy}$ been written, and continued to be written. At one time, a single species of animal is multiplied into three or four; as, at another, three or four species are mingled into one !

"The three genuine descriptions refer to three animals sufficiently distinguishable by their respective sizes, figures, and colours, but more than all by the state and situations in which they are respectively found, by their adaptations to human uses, and the manner in which they are made available. But, when we have ascertained the distinctions which thus separate the three animals, we are still surrounded by certain difficulties in the due appropriation of their names. Two of the names, familiar to European ears, are uniformly misapplied; and the 
third is never brought into use. The two names that are uniformly misappropriated, are Paca and Llama; and the name which is uniformly neglceted is Guanaco, or Guanaca.*

"The animal which I shall first describe is a native of the highest regions of the South American Andes, below the line of perpetual snow, is small, and solely celebrated for the lerigth and fineness of its wool. Its leg's are shorter even in proportion than those of either of the other animals which are perpetually confounded with it; and it is also remarkably distinguished by the shortness of its muzzle, or the roundness of its head and face, which latter, from that configuration, has been said to show some resemblance to the human countenance. It is this animal which is commonly called the Tigonia, or Ticunia.

"Of this species there is no specimen in the Zoological Garden. One, which was in His Majesty's collection a short time since, and one which was in France, lived only about a year. The climate and situation were neces-

* Sometimes written Huanaco, or Huanaca; but always pronounced Guanaco, or Guanaca. 
sarily fatal to them; for, if any where in Europe, it must be obvious that Mont Blanc should have been the range assigned them!

"The second species is the Guanaco, of which the individual here before you is commonly called the Llama, and Brown Llama. The form, colour, and magnitude of the animal are under your eyes; and I have only to add, that it is an animal which has been caught in its wild state, and which is not known to have been ever domesticated; and wholly unentitled, therefore, to the name of 'Lama' (Cattle.) The occurrence of the Guanaco in the wild state, sometimes to the discomfiture of the huntcrs of the Vigonia, (in the same manner that a whale or shark disturbs a herring-net,) is thus described by Captain Shelvocke:-' The Vigonias are often hunted after the following manner;Many Peruvian Indians gather together, and drive them into some narrow pass, across which they have previously extended cords about four feet from the ground, having bits of wood or cloth hanging to them at small distances. This so frightens them that they dare not pass, and they gather together in 
a string, when the Indians kill them with stones tied to the ends of leather thongs. Should any Guanacos happen to be among the flock, these leap over the cords, and are followed by all the Ticumnas. These Guanacos are larger, and more corpulent ; and are also called Viscachas.'

"I come now to the third description of South American Camel, and that which, exclusively, should be called Llama, or the sole cattle, or beast of burthen, or demesticated animal, for food and fleece, of ancient Peru and Chili; and that commonly intended by the name of ' Llama of Peru,' or' 'Hueco of Chili,' or ' South American Shecp,' described as a beast of burthen, and even ridden upon as a horse by the Spanish conquerors, if not by the Indians before them. But it is this animal, much more than either of the preceding, which presents difficulties in Zoology. As the Tigonia and Guanaco are never found domesticated, so the Llama is unknown in the wild state, or as a beast of chace. Is, then, the Llama a domestic variety of the Guanaco, (for this question only can be admitted;) or is it a domesticated 
species, of which the original stock is either wholly lost, or has never yet discovered itself to view?

"The relative places or haunts, as also the magnitudes, figures, and properties of the Vigonia and Guanaco, are plain, and can be the subject of no ambiguity whatever. The Vigonia is prepared to live in the highest habitable regions of the South American Andes, is the smallest animal of its kind, has the finest and warmest clothing, and has very different proportions, and a very different head and face from those of the Guanaco; and the Guanaco, besides being differently figured, is much larger, less warmly covered, and more prepared to descend from the cold regions of the middle mountains into the heats of the plains below. But, as to the Llama, this is never seen in a state of nature, either upon the plains, or upon the mountains. Is it, then, a variety of the Guanaco, produced by domestication?

"When the Spaniards conquered Peru, they found the 'Llama' in the possession and daily use of the Indians. They ate its 
flesh; they wove its wool into cloth; and they employed it as a beast of burthen. 'In those places,' says Zarate, a Spanish officer of government, in Peru, in the year 1544 , "where there is no snow, the natives want water, and to supply that want, they fill the skins of Sheep (Llamas) with water, and make other, living, Shcep carry them; for it must be romarked, that these Sheep of Peru are large enough to serve as beasts of burthen;' to which he adds, that 'they can carry about a hundred pounds, or more, and that the Spaniards ride on them; and they can go four or five leagues a-day. Their flesh,' he subjoins, " is as good as that of the fat Sheep of Castile;' and, in his time, it was commonly sold in the markets, in all those parts of Peru where the animal was kept._- That,' says he, 'was not the case when the Spaniards first came; for when one Indian killed a Sheep, his neighbours came and took what they wanted; and then another Indian killed a Sheep in his turn.' In another sentence, Zarate might seem, at first sight, to authorise the belief, that the Peruvian Indians had 
two species of Llama, or two domesticated creatures, useful for food and clothing; for he says, that 'these animals were of great use and profii to their masters, particularly that species named Pacas, which have very long fleeces.' But, in this place, the Spaniard, intentionally or otherwise, assuredly unites, in one supposed domesticated? species, the several virtues of the domesticated animal and the wild; and his Paca can be no other than the Alpaca of Shelvocke, which is also his Vigonia; and of which lie says, that 'it is shaped much like the Llama, but much smaller and lighter, its wool being extraordinarily fine, and much valued.'

"We see, here, that the fine-woolled animal is the Yigonia; that its figure, though smaller, much resembles that of the Llama; and in particular that, as I have recited from my author, the legs of the Vigonia are shorter even in proportion than those of the Guanaco, which also surpasses it, both in height and in fulness of body. But still, where is the natural stock of the Llama?*

* It is the Llama only, and not the Guanaco, which is represented in tine annexed engraving. 
"The Llama, like the Tigonia, is lower iipon the legs than the Guanaco; and, like the Tigonia, it is a wool-bearing animal; but its wool is coarser. Altogether, there appears to be a degree of resemblance between the Ilama and the Tigonia, closer than that which subsists between the Llama and the Guanaco. Both are celobrated for wool, and both are remarked for comparative shortness of legs; but, besides that the head and face of the Tigonia are unlike those of the Llama, and that the head and face of the latter differ but little from those of the Guanaco, there are other reasons which forbid us to suppose the Llama a domestication of the Vigonia, any more than of the Guanaco. The Llama, which is larger than the Guanaco, is much larger, therefore, than the Tigonia; and the wool of the Vigonia, or wild species, is finer than that of the Llana, or domesticated breed. The reverse, as to size, according to all cxperience, should be the fact, if the Llama were a domestication, either of the Tigonia or Guanaco.

"If the figure, in the mean time, of the Llama, could be reconeiled with that of the 
Guanaco, all other difficulties, in the way of deriving the former from the latter, might be readily thrown aside. The colour of the Guanaco is uniform, or at least, it is never pied; and this uniformity is natural in the wild animal, though without excluding the accidental occurrence of white, dark-coloured, or even black-coated individuals. The coat of the Llama is often pied. It commonly varies between white, grey, and russet; and individuals are sometimes seen, of which one half of the body is of an uniform dark colour, and the other half of an uniform white. The Llama which you see here is wholly white, in the same manner that you see a white horse, or a white cow. But a White Llama is so far uncommon in Peru as to be remarkable; and, like a White Elephant, a White Doe, or other white animals in general, it commands, in its native country, more or less of superstitious veneration. In the time of the Incas, and in the view of the Virgins of the Sun, and of the worshippers in the Peruvian temples, a White Llama was holy.*

* See, The White Llama; a Story of Peru. By 
"But, now that I have endeavoured to explain, at so much length, the proper distinctions that are to be made between the three several kinds of South American Camels, and to show you that the specimens in this Garden are properly to be called the Llama, or domestic animal, and the Guanaco, or one of the wild species, while the Tigonia, or second wild species, is wanting; I will not add to my present remarks any thing that relates to what is more generally known of the species, but content myself with giving you, some day, for your leisurely examination, a tabular view of the names, and of the most obvious distinguishing particulars, of the three South American Camels; and in which, as you will find, I shall venture to prefix to each a new scientific name of my own, by the adoption of which, as well as of my discriminated English names, all the existing confusion, as I apprehend, would be fully and finally removed. I leave nothing uncertain, except the stock of the Llama; hesitating as I do, the Author of Keeper's Travels in search of his Master. 
either to receive that animal as a domesticated Guanaco, or to suppose it a separate species; but yet, admitting the possibility, that the original list of native species, though not so numerous as five, nor even as four, was really three, and not two only (which might be made the Guanaco and Hueco, of Molina, without his three additions, ) and that the Hueco (assumed as a Wild Llama,) survives only in the domesticated breed. I will only add, that the story which has been spread, that the saliva of these animals has something venomous in its quality, is unfounded. The practice of spitting when offended is one of the points of similarity between the Guanaco and the Llama, and, perhaps, between both and the Vigonia. But, as respecting the Guanaco, the author of the ' Menageries' assures us, that he has received a plentiful share of the saliva in his face, without experiencing any of those blisters which travellers used to describe with great minuteness; and, with respect to the Llama, which was probably the animal alluded to by travellers, Zarate, while he describes one of the occasions upon which that particular ani- 
mal employs this means or annoyance upon being offended, charges nothing against the saliva, except 'a very bad odiour :-'-' When,' says $\mathrm{n}$, ${ }^{6}$ there is a man on one of them, if the beast is ired, and is urged to go on, he turns his head round, and discharges his saliva, whicls has a very bad odour, into the rider's face."--In this manner finishing his remarks, the Admiral, after making a courteous bow to the ladies, and taking a cordial leave of the children, procected toward the gate of the Garden, and drove home to dinner.

"This Black Goat," remarked Mr. Dartmouth, "which you san in the same enciosure with the White Llama, is a variety of the Cashmere Goat, so much celebrated for the fineness of its wool, which is wrought into the Cashmere shawls. Several of these Goats have long been at the farm of the East India Company. The Casinmere Goat is usually white." 


\section{ORIGINAL POETRY.}

INJURED INNOCENCE or,

\section{A CAT SUSPECTED!}

BY THE AUTHOR OF "THE MUMMY."

" Vous voyez qu'en ce fait la plus forte apparence Peut jetter dans l'esprit une fausse créance: De cet example-ci ressouvenez-vous bien, Et quand vous verrez tout, ne croyez jamais rien !"

THE night was dark, the wind was high, And Romeo had no hope of rest; Though fell destruction hover'd nigh, And thunder rattled through the sky, The thirst of vengeance fix'd his eye, Firm was his Cattish breast!

Gigantic thoughts his soul inspired, He burnt to clear his injured name; For Willian's wicked tongue aspired (By Envy, Hatred, Malice, fired, And Calumny, that fiend untired,) To hurt his well-earn'd fame! 
Eggs had been missing from the nest, And broken shells were found;

So Romeo, of all Cats the best,

Of worth to stand the hardest test,

W'as with the charge of theft oppress'd,

By WILL, the neighbourhood round!

And Roveo was often watching seen

Close to the very place

Whence the eggs had stolen been;

And, then, his altered look and mien,

His body fat, so lately lean,

Gave to the rumour grace!

Straight to the stable-door he went,

(Nought could his rage impede,)

Firm and resolved his mind was bent

Upon one fix'd and high intent,

Determined nothing should prevent

A fierce and bloody deed!

He reach'd the door, he hurried in,

And up the stairs he goes;

He goes, to perish, or to win,

And soon the battle's fearful din

Shook windows, mangers, stalls, and bin,

So loud the clamour rose!

Old Willias, frightened, rush'd up stairs,

And found this best of Cats,

At whom with heart-full dread he stares,

That scarce to look around he dares, 
And upright stands his trembling hairsHad slain six monstrous Rats!

These were the thieves that stole the eggs, It plainly now appear'd ;

William, with woxder, cried "I' figs!"Arid scarce could stand upon his legs, Whilst he most humbly pardon begs, And Romen's fame was clear'd! 


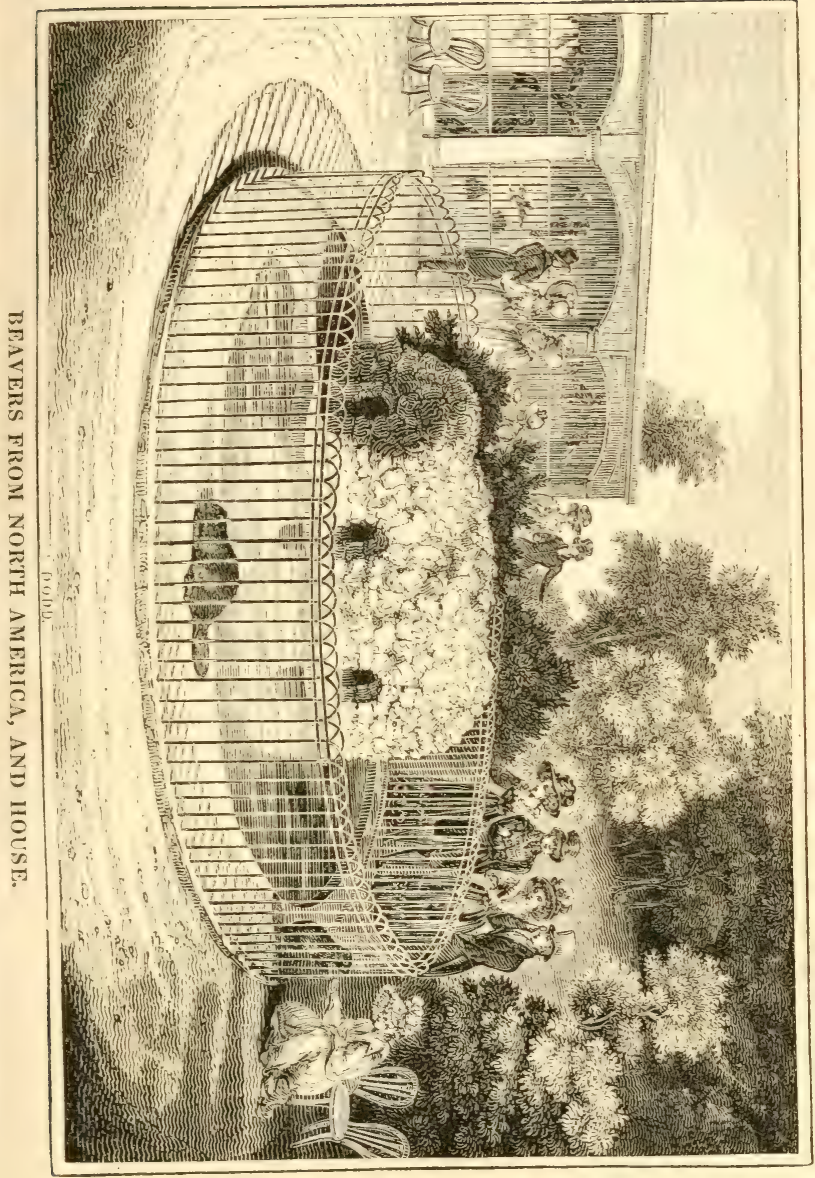





\section{ANTELOPES AND UNICORNS.}

NYL-GHAC, OR PAINED ANTELOPE.-DEET.-OX.AXELOPE. GNU. -E"U.-IHIOCEROS.-ORYX.UAICORA.-FIFTEEN UNICORNS IN TIIE ROYAL PARK IN ABISSINIA.

"THE Admiral is certainly in the right," said Mr. Dartmouth, as, one day, he was leading Miss Aston, and a friend of that young lady, through the yard which discovers the Ostrich and the Nyl-ghan; " the Admiral is certainly right, and we are but in the dawn of Zoology, or there would not be the confusion which commonly prevails, respecting the very distinguishable genera of the Deer, Ox, and Antelope. There are striking peculiarities in cach; but, as we pass by the Nyl-ghau, let me ask whether either of you ladies have yet remarked how thoiroughly this Antelope, like its fellows, is distinguished, upon the one hand 
from the Bull or $\mathrm{Ox}$ genus, and upon the other from the Deer; in the one respect by its horns, and in the other by its muzzle?"

The ladies confessed that they had not yet made the observation; and Mr. Dartmouth thus explained his meaning:

"I shall say nothing at present," added that gentleman, "of the manner in which the horns of the Antelope at once differ from those of the Deer, and make approaches towards those of the $\mathrm{Ox}$; but only beg of you to remark, how very observable is the peculiar setting-on of the horns, in the instance of the Antelope! Look at this Nyl-Ghau, and look at what is called the Common Artelope,* in the western division of the Garden; and look at all the other animals which you meet with, of the kind properly to be called Antelopes; and you will observe, that while their horns partially approach those of the Ox, as well in their figure, as in their texture, and their permanence, they differ as much from those of the $\mathrm{Ox}$, as from those of the Deer, in the manner in which they are set upon the head! Look at the Zebu, and

* Capra cervicapra.-LinN. 
NIL-GHAU, OR PAINTED ANTELOPE. 63

look at the Brahminee Bull, as well as at our domesticated Bulls, Cows, and Oxen; and you will see that the horns, in that genus, grow immediately above the ears, a position which also much resembles that of the horns of the Deer. But, look at the Antelope's, and you will find that they stand half-way down the forehead!"

"Well! that is a plain distinction indeed," said the fair Zoologists; "but how, then, does it happen," added Miss Aston, "6 that the Nyl-ghau is popularly so called in India; for I have heard you say, both that the name means a Blue, or Grey, or Bluegrey Cow; and, also, that you have much more confidence in the popular names of all countries, than in those of scientific writers?"

"6 You must understand that the word Ghau or Cow (for these two are in reality the same,) has no original meaning but the general one of beast; and that this general term, anciently, as in many cases at present, was equally applied to all the several kinds of Ox, Antelope, and Deer; so that, by the name Ghau or Cow, either of those animals might be intended. As an apposite example, 
the name Zebu, which means an $0 \mathrm{x}$, is obviously the Ze or Tze, of the Hebrew, which the trarislators of the Bible have rendered by Roe or Ree Deer, and which critics have said, should have been rendered by Gazelle or Antelope.* But, further, as the several names of all animals are confounded, so also are their attributes. That beauty of the eyes, which the Arabs attribute to the Gazelle or Antclope, the ancient Gresks attributed to the Cow: and with us, in England, it is said, that the most beautifui of all eyes are those of the Stag! Lastly, you must be informed, that the name 'Cow', or ' Ghau,' in its original sense, is not the name of the female, but of the species; in the same manner that 'Mare' is an original name of the whole species of the 6 Horse.' In the present case, the Nyl-Ghau, or Elue, or Grey Cow or Bull, $\uparrow$ is the male only; for

* Tze is, to this day, a native African name of the Antelope.

+ Called also the White Antelope, as well as Antelope Picta, or Painted; île latier upon acount of the white sjots upon the neck and sides, and each fore-foot of the nale; and of two white bars, and 
NYL-GHAU, OR PAINTED ANTELOPE. 65

the colour of the female of the species is a pale brown. I have to point out, also, one of the obvious distinctions between the real Antelope and Ox. The nose or muzzle of the Antelope, as in this Nyl-Ghau, is sharp, like that of the Deer, while that of the $\mathrm{Ox}$ is broad. An Arabian poet calls the Cow, "the broad-nosed mother:' But by this rule also, as well as by others, we ascertain that the Gnu, if not an $\mathrm{Ox}$, is at least a Buffalo-for its nose is broad. I will add a little of what relates to the habits of this Nyl-Ghau, or White, or Painted Antelope. Though it makes so gentle an appearance in this place, there are several curious anecdotes related of its manner of attacking, and preparing to attack, whatever offends it, or seems to it likely to be an enemy. Two, which were kept in England, some years since, in a little enclosure at Lord Clive's, when at a considerable distance from each other, would prepare themselves by falling down upon their fore-knees; and three black, upon the fore-part of each foot of the female. 
each progressively advancing in that posture, when they came withia a few yards, would make a spring, and then dari against each other. Two, which were kept in a stable, by the late $\mathrm{Dr}$. Hunter, were accustomed to fall upon their fore-knees when any stranger approached, and sometimes even upon his own approach; but he, not discovering the hostility implied by such a novement, supposed it expressive of a timid and obsequious humility! A labouring man, coming to the outside of the pales of an enclosure which, at the time, contained one of the finest of these animals that had ever been seen in England, but which the man did not know to be there, was attacked by the Nyl-Ghau with the swiftness of lightning. The animal darted against the paling with such violence that he shattered it to pieces, and broke off one of his horns close to his head. The public generally do not like this sort of amusenent, leaving children out of the question. The female of this Antelope is of a pale brown colour."

"I observe," said Miss Aston, "that the 
ANTELO?ER.-C: 'Z̈LLLW.

word Antelope is spelle?, sometimes fintelope, and sometimes hintilop:; that is, either with an $e$, on with an $i$ ?"

"It has been scid, that the name Pantholopos, in the ancient language of Eigypt, signified the Unicorin; but did it cio this, otherwise than as the Antelope was mistaken for that strangely-disputed animal? For my part, I suspect the word Pantholops, to be at least of Greek formation, and to refer to that beauty of the eye for which the Gazclle (the Antelope Dorcas of Buffon) is so much celebrated in Arabian poetry. I think that the Greeks knew little or nothing of the whole Antelope species, but through the Arabs; and that in the name Pantholops, they adopted the Arabian encomium of the Gazelle. Besides, the Antelopes, through almost every variety, are distinguished, not only for the beauty of their eyes, but for the quickness of their sight."

"Is this Antelope before us the Gazelle?"

"By no nieans. This is the Common Antelope. Two years ago, his Majesty had a Gazclle at Windsoi; but it is now dead. Its height was only twenty inches, and its 
length, from head to tail, but twenty-two. Its colour was uniform, its coat beautifully sleek, its body extremely graceful, its head and neck peculiarly light and airy, its ears highly flexible, its eyes most quick and brilliant, and its legs as slender as a reed. It has been said that, in the figurative language of the Arabs, to resemble a Gazelle is to possess perfect beauty. These elegant little animals are spread, in innumerable herds, from Arabia to the banks of the river Senegal, in Africa; and though you eat the flesh of so many pretty creatures yourselves, you will lament to hear, that the Gazelle is the constant prey of the Lions, Panther's, and Leopards, and of hunters who chase them with the Dog, Hunting Leopard, and Falcon!"

" Oh, yes!" cried Jane, "I am so sorry for the poor Gazelles! But Antelopes, Uncle, have two horns; and why, therefore, should they have been called Unicorns?"

There is scarcely a stronger example of the errors and confusion of Natural History, than that which is presented in all that connects itself with the Unicorn. The Unicorn, 
as is perfectiy boyond contworary, is the Rhinoceros."

6" The Rhinoceros, Lncle!" exclained George: "What, is it the Rhinocers that is painted like a Horse, as a supporter to the King's arms?"

"I I belicre that have detected tho sources of every part of that strange compound form which is the Unicorn of picture; but the Unicorn of nature, and of the Book of Job, (which latter is so commonly appealed to upon the subject,) is certainly no other than the Rhinoceros. I shall surprise you, if, some day, I tell you, from what accumulations it has evidently happened, that the Unicorn of picture has become compounded of the Rhi. noceros, the Hippopotamus, the Antchope, and the Horse; but you must be contentsd, for the present, with what I can say about such parts of the figure and description of the Unicorn, so called, as have their onigin in the Antelope. You know that the Unicom is painted with cloven-hoofs, like a Decr, or like an Antelope; and witl a single hom upon its forehead, spirally twisted. Frow, the Antholopos, or Pantloolopos, of the carly Greets 
writers, was described by them as an animal with long horns, jagged like a saw ; and, in this, they had reference to the annulations which distinguish the horns of at least a part of the Antelopes, and which you observe in those of this Antelope before us. But the Egyptian name of the Antelope was Oryx, rather than Pantholopos; and the Oryx was represented, in certain rude Egyptian sculptures, with a single horn. It followed, that the Greeks, who, as I have said, know little or nothing of the Gazelle or Antelope but by report, - who were superficial in almost every thing, - who knew as little of the Rhinoceros as of the Antelope; and who did but gaze, without understanding, upon whatever was Egyptian, believed the Orix, Pantholopos, or Antelope, to be single-horned, and to be itself the Unicorn or Rhinoceros, of whose single horn they had listened to the report. It is this idle notion, then, (originating with the Zoological ignorance of the Greeks, that the Unicorn is the Antelope, which has been one foundation of the pictured Unicorn of heraldiry, and which is still the source of incessant rumours, -now, that 
the Unicorn, in the shape of an Antelope, has been found in Africa, and now, in the Indian mountains of Himalaya. To stories, that an Antelope with a single horn, placed after the manner of that of our pictured Unicorn, is found rudely traced in a cave or caves of Southern Africa, it is sufficient to reply, that it consists entirely with the manner of such draftsmen as the Bushmen of the Cape of Good Hope, as it also would with the Indians of America, (rude, but accurately characteristic,) to represent the profile of an Antelope with no more than a single horn. Standing in profile, one horn would be held to hide the other; and why should the profile of an Antelope contain two horns, any more than the profile of a man, two ears or eyes? M. Cuvier has properly remarked, that many of the Egyptian representations of quadrupeds have only one leg before, and one behind ; and adds, "Why, then, should they have two horns?" But the learned naturalist had no need of supposing a religious rigour to demand that style of representation from the artist. It is the natural style alone; it is what any child would 
do to-day among ourseives; and it is what I am in possession of American Indians' drawings, carvings, and sculptures, to show, has been always done in the IVestern world, as well as in the Eastern, I shall not now say more, of the figure of the painted Unicorn, than to add, that to its confusion with the figure of the Antelope we owe, not only its cloven hoofs and annulated horn, but its beard, the tuft of hair upon its tail, and the setting of its single horn so low upon its forehead. I have already called upon you to observe, that this situation of the horns of the Antelope distinguishes the species so readily from the species of the $\mathrm{Ox}$, as to excite our wonder that it has not received considerable attention from professed Zoologists at least, if not from mankind in general, in all ages, and in all countries."

"It seems clear," said Mrs. Aston, "that the Unicorn of Job is an animal peculiarly distinguishable for its strength, if not for its indocility, and such as can have no resemblance to even the most powerful of the Antelopes. It is mentioned in Job, only as an example of the limited powers of man." 
"Edward Webbe," added Mr. Dartmouth, " an English traveller, who visited Abyssinia in the sixteenth century, has spoken of Elephants and Unicorns together, and in great numbers, as kept in a park or menagerie, at the court of Prester John; and, for so doing, is reproached by Purchas as a ' fabler.'* But if, by a Unicorn, we will but understand a Rhinoceros, every thing will disclose itself in the plainest manner possible; for Abyssinia is one of the native countries

* "I have seen," says W'ebbe, "in a place like a parke, adjoining to P'rester John's Court, three score and seventeen Unicorns and Elephants, all alive at one time; and they were so tame that I have played with them as one would play with young Lambes." Purchas, for this passage, ventures to call Welbe "a mere fabler;" and this, not because he talks of haring seen Unicorns alive, not for the harmlessness and playfulness which he ascribes to them and to the Elephants, and which he states himself to have seen of both, but only for the largeness of the number. But the number of the animals collected for the royal park, in Abyssinia, their native country, offers no difficulty whatever; and if, by " Unicorns and Elephants," we understand Elephants and Rhinoceroses, Webbe is instantly relieved from every suspicion of fabling. 
of the Elephant and Rhinoceros, and there is nothing extraordinary, therefore, in the proposition, that a park or menagerie of the sovereign of the country should contain many specimens, either wild or tame. But I value the passage in Webbe still more, because it assists in showing, that in the English of the sixteenth century, the era of the translation of the Bible, it was usual to call by the name of Unicorn, the very animal which now, with more modern and Greek predilections, we denominate Rhinoceros. But the horn of the Rhinoceros is upon his nose, and not upon his forehead; and that is the meaning of the name Rhinoceros, and of the Hebrew 'Reem.' The Greek translation of the word Unicorn would be Monoceros.

"Before we part with the Rhinoceros, let me remark, that the animal was as familiar to the thoughts, at least, of the Hebrews, as it was foreign to those of the Greeks; and thence an incessant subject of Hebrew metaphor. The Rhinoceros has the thickness of his bony hide for his passive defence, but the horn upon his nose for his 
active weapon. As he adrances in age, his horn lengthens, or is 'exalted, or is raised higher; and, in proportion to the growth of his horn, so is his safety, or his prosperity, or his means of resistance to his. enemies ; or, by metaphor, to the assaults of any species of adversity. But, these considerations in your mind, you see why the Hebrews describe God as the "horn of their saliation,' safety, or defence; and why, to say that they were in prosperity, or strong against the buffets of fortune, they said, that their "horn was exalted.',"

"C Concerning the Antelope, brother," said Mrs. Aston, "I have met with an interesting remark, by Mr. Colebrooke, the distinguished writer upon the antiquities and economics of Hindostan; namely, that the waters of the Ganges are held sacred only so far toward the sea as its banks are frequented by the Antelope. A pleasing superstition, which he explains, by observing, that where the soil or surface ceases to be fit for the Antelope, they cease also to be fit for agriculture, giving place to the salt-water of the Delta of the river." 
"I agree with you, that the remark is interesting, and the superstition for the fancy pleasing, because they associate themselves with the history of the tillage of the earth, and with the primary and sweetest interests of mankind. By the way, considering this Indian sanctity of the Antelope, or of the Orix, the Egyptian name, I am half-tempted to conjecture a relationship to the city and temple of Orixa, or Orissa, upon the coast of the Deccan, the site of the worship of the Divinity under his great and venerable name of Jaca, Xaca, Shaca, or Saca Nath, more commonly written Jaggernath; and which our merchants even convert into Jaconot, and Jaconet, in distinguishing the muslins that are the peculiar manufacture of its inhabitants."

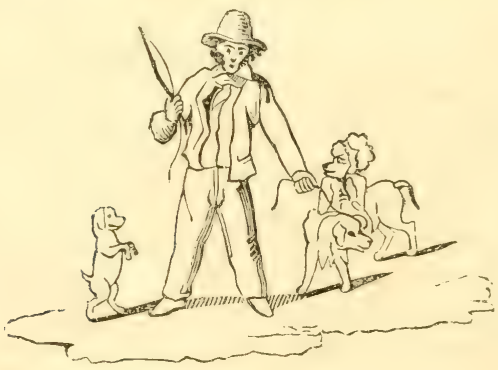




\title{
ORIGINAL POE'TRY.
}

\section{THE FALL OF PRIDE.}

\author{
BY HANS COLEMAN.
}

Two cats there were, - of high degree

Was one,-and one was low :

One was a Wesî-end Belle, d'ye see,-

The other lived at Bow.

And what was strange,- - you 'll wonder how, Low, lived the nobler beast; Whereas the lower cat, I vow, Lived twice as high, at least.

The truth was this, that next the sky,

A garret one possess'd ;

The other cat on rugs did lie, And parlour carpets press'd.

The poor one sat on Goody's lap,

Of woollen,-not of silk, -

There she would take her daily nap,

Or lap her watery milk. 
The one of rank her signal knew,

For she was Fortune's care :

The milkmaid, Molly, crying " mew !"

Hail'd her the favourite there.

She minced her dainty mince-pie crumbs

In ladies' laps, by turns,

And purr'd, just like a bee that hums,

Or turner's wheel, - that turns.

The other cat's old Goody Gray

Made catsup, writers write,-

But careful saw, each busy day,

Her cat sup, every night.

The tald is told, she held it sin

What once her cat befell,-

When boys a kettle tied of tin

To her unfolded tail.

And well for them, they kept aloof,-

'Tis clear there was no clause,

Just then in her most just behoof

To keep them from her claws.

She, scampering wild through lane and street,

(For fear, even soldier's drives;)

Though featly using her four feet,

Lost one of her nine lives!

Of brownest bread the low cat ate,

But well the other said,

Such stuff was never made for great-

Big folks that were. well-bred. 
Some men are proud of being poor :

How proud the wealthy crowd!

And both are past all human cure,

In both, the flesh is proud.

These cats, intent a brook to cross,

Upon its slight-bridge met;

In hot defiance there did toss

Their heads,- their rage to whet.

There was but room for one to pass-

But which was that to be?-

'Tis woman's bane, too oft, alas!

To hate equality!

They stood and paused,-but not in fear,-

Prepared their paws to lance,-

Nor could (tho' deep the brook, and clear)

They brook each other's glance.

Catastrophe must now begin!

Each cat began to flout

And fight,-and so they both fell in

Because they'd both fallen out.

Well-founded is their tale of woe :

(Chance foils the loftiest cause!)

High files of Chancery records show

"Found dead," the Inquest was. 


\section{BEARS, BEAR-PITS, AND BEAR-GARDENS.}

PARIS-GARDEN.- OLD AND NEW BEAR-GARDENS.GLOBE, HOPE, AND OTHER THEATRES.-PRINCELY PLEASLRES OF KENILWORTH.-BEAR-PITS, PONDS, AND SCAFFOLDS.-IMPROVEMENTS FOR THE GARDEN OF THE ZOOLOGICAL SOCIETY.-NATCRE AND IIABTS OF THE POLAR BEAR. - ATTACHMENTS OF BEARS AND OF WHALES.

"I IfHALL be excused, perhaps," said, one day, Mr. Dartmouth, "6 for the remark, if even it applies only to a whimsical coincidence of names, that when Bears were formerly kept in England for public show, the place of their abode was called Paris Garden; and that, now, we find them, in what is a copy of a garden in Paris-the Jardin des Plantes. At the same time, there is possibly more than a coincidence of names; for Paris may have given the example in both instances !"

"Oh! where is Paris Garden?" said George; 
" and did it used to have a Bear-pit, like this which we are now seeing?"

" Paris Garden, my dear George, is the name of an ancient district, upon the south bank of the Thames, or in what we call Southwark, nearly opposite the Church of St. Paul, or rather Baynard Castle; and close to the eastward of the foot of the present Blackfriar's Bridge. Or, to describe the situation otherwise, it stood upon Bankside, and in that part of it which was called West."

"The banks of the Thames, that are opposite St. Paul's, called WVest?" cried George.

"Certainly, my dear ;" and when the river Fleet, meandering from the foot of Hampstead Heath, washed the banks upon the top of which rose the westward wall of London, every thing, too, upon that other side of the water, which lay to the west of the little silver stream, was called west of London."

" Oh ! I understand; those were very ancient times indeed! And so, there was a Bear-pit in Paris Garden?"

" Not exactly a Bear-pit; for, in that par- 
ticular, as $\mathbb{I}$ mean to argue, the Bears were better used than now. But, what was bad enough, there were Bear Gardens, where, as the old writers have it, 'Bowlls and Beares were bayted,' for the amusement of the Court and People."

"For the amusement of the Court?"

"Oh, yes; Bears and Bearwards were part of the Royal Establishment, and even of the establishments of all the greater nobility."

"And when did that barbarous practice begin in England?"

"I little doubt that long before the arrival of Julius Cæsar in this island, the Gauls in Gaul, and the British Gauls in Britain, made Bear and Bull-baiting a diversion; and that they did not even wait for the assistance or example of the Romans, in order to build Circuses, or circular theatres, for enclosing the arenas, and accommodating the spectators. Be this, however, as it may, we have no proof of the commencement of the practice, nor any earlier notice of it, perhaps, than in the reign of Henry VII. when it is shown to us in its full vigour and lustre. The celebrated Northumberland Household 
Book, recording' ' al manner of rewardis customable use yearely to be yeven by my Lorde to strangers, as players, mynstraills, or any other strangers, whatsomerer they be,' mentions, ' Furst, my Lorde usith and accustomyth to gyff yerely the Kinge or the Queene's Barwarde, if they have one, when they custom to come unto hym, yearelyvj. s. viij. d. ;' and, 'Item, my Lorde usith and accustomyth to gyfe yerly, when his Lordship is at home, to his Barward, when he comyth to my Lorde in Christmas, with his Lordshippe's Beests, for makynge of his Lordshippe's pastyme the said xij. daysxx. s.' Descending a little lower, we find Bear-baiting in much esteem in the time of Queen Elizabeth, when it formed a part of the 'Princely Pleasures of Kenilworth,' in the year $15 \% 5$. 'It was a sport very pleasaunt of these beastys,' says the historian of those revels, "to sce the Bear, with his pink nyez, leering after his enemiez approch ; the nimblress and wayt [watching] of ye Dog to take his adrantage; and the fors [force] and experiens of the Bear agayn, to auoyd [avoid] the assaults: if he wear bitten in 
one place, hoow he would pynch in anoother to get free: that if he wear taken onez, then what shyft, with byting, with clawing, with roring, torsing, and tumbling, he would work to wynde hymself from them; and when he was lose, to shake hiz earz twyse or thryse, wyth the blud and the slaver aboout hiz fiznamy, was a matter of a goodly relief.In 1600, under James I, Sir John Davington, the then Master of the Bears and Dogs, and who was rewarded with a fee of a farthing a day, was commanded, on a short notice, to exhibit before the Queen, in the Tilt-yard; but not having a proper stock of Bears, (apparently, on account of a partial disusage, he was obliged to apply, for help, to Edward Alleyn, afterward founder of Dulwich College, and then Keeper of the King's Wild Beasts, and Master of the Royal Bear Garden on the Bankside, Southwark; and to Philip Henslow, the owner, or lessee, of the Garden. But so much for the antiquity and ancient dignity of Bear-baiting in England; and, as to the nature of the Old and New Bear Gardens, which adjoined each other, in the district, honour, or liberty of Paris Gar- 
den, they were fields or slips of ground, containing a theatre each, and grass and ponds for the exercise and recreation of the Bears. Plans of London, of about the date 1574 , exhibit small Circuses at this spot, described as for ' Bowll Bayting' and 'Beare Bayting."

"How shocking, to think that pastimes so odious and so cruel, should have given pleasure to persons of the highest rank and best education in the country;-have received even the sanction of the Prince, and have been resorted to even by Queens !"

" I shall not say all that is capable of being said upon both sides of those questions; but, as to Queens, you are aware that the Bull-fights of Spain are a royal resort, and that, in many countries, the execution of criminals is attended by theil. highest nobility. For the rest, though Bear-baiting, and all similar pursuits, are things full of evil; yet it is to be acknowledged, that they sometimes make us acquainted, both with the intellectual and physical powers of animals, in a degree which we should no otherwise attain, and increase, therefore, our knowledge of nature. Who, 
for example, would have thought, before the experiment of the late Duke of Cumberland, that in fair fight, a Stag would overcome a Tiger? But, further, you must understand, that in all countries and ages, the Court and the People make one class, and the reformers of morals another. Besides the natural practice, and even duty of Courts, to identify themselves with the great body of the People, and therefore to sanction and uphold, in pastimes as in every thing else, what belongs to popular customs and manners, the persons composing Courts have the same national tastes and national clucation with the People at large; and, in our own day, we see princes, peers, and lords and ladies, mingling and sympathising, or forming a single class, with the coarsest rabble, in the enjoyment of the popular diversions of the age. The same has happened before, and will always happen again; and yet, mingled with the mass, both of the Court and of the People, there will always be persons to contend, either for greater innocence, or more refinement, in the practice of the day. As early, at least, as the reign of Henry VIII. we have one ex- 
ample extant, in the verses of Crowley, of a severe reproof of Bear-baiting, though the writer's objections are founded, not upon the sufferings of the Bear, but upon the 'ful ouglie sight' which they afford; the extravagance of paying a half-penny for admission, often by those who could not prudently afford $\mathrm{it}$; and the supposed impiety of applying to the purpose of diversion, any money really superfluous, and which, in conformity with an old exaggeration, the poet teaches should be given only to the poor. He is jealous that the pence of the multitude should go into the pocket of the Bearward, or Manager of the Theatre! I will repeat some of his lines; and in these, as elsewhere, you will observe, that in those Romish times of England, as still in every Roman Catholic country, Sunday was the express day for theatrical entertainments :

'What follie is this, to keep, with danger', A great Mastiffe Dog, and foule, ouglie Bear ; And to this end,-to see them two fight, With terrible tearings, a ful ouglie sight: And methinkes those men most fools of al, Whose store of menry is but rery smal; 
And yet, every Sunday, they wil surely spend

One penny or two, the Bearward's living to mend

At Paris Garden, each Sunday, a man shall not fail To find two or three hundred, for the Bearward's vale;

One halfjenny a-piece they use for to give,

When some of them have no more in their purses, I believe :

Wel! at the Last Day, their conscience wil declare, 'That the poor ought to have all that they may spare : If you, therefore, give, to see a Bear fight, Be sure God his curse upon you will light!" "

"6 Well! I am glad that, even if no earlier than Henry VIII. religion was held, at least by some persons, as at variance with these sports; and I hope the Clergy were at all times their zealous reprovers?"

"For my part, my dear sister," replied Mr. Dartmouth, "I I think that the verses which I have repeated, and the age in which they were written, afford strong presumption of a fact which yet I do not know; namely, that their author was a Reformer, and a renouncer of the ancient religion of the country. All religious establishments are parts of the civil government; and civil governments, as I have already intimated an opi- 
nion, always stand more or less, by the customs of the People. I could add much, too, upon the notorious and uniform disposition of the Church of Rome, to concede almost every thing to the inclinations of the People, compounding only for an implicit confession of its faith, and implicit submission to its authority. But I am content with what is historically urquestionable; namely, that the Romish Church has always lent itself to the sports and recreations of the People, almost whatever they might be ; and that it is almost the Reformed religion alone, which, at any time, has interfered with, reprehended, or suppressed them. You will remember that the "Book of Sports" was the great stumbling-block between English Protestants and Roman Catholics, at a later date in history; and, in truth, the two Churches stand upon such opposite foundations, affecting these and all other questions, that here, as in every thing else, they are the most malterable antagonists. The Reformed Church stands upon a theory defended as true; the Pomish Church upon a practice defended as ancient ; the one appeals to reason, the other to usage, 
custom, and tradition. Now, the sports of the people are among the things which may be left upon the footing of tradition, custom, and usage. But, whether I am right or wrong as to the temper of our Roman Catholic times, in reference to Bear-baiting and similar sports, you will be pleased to hear, that at any rate, after the Reformation, Fngland had at least some portion of its Clergy to condemn them. On a Sunday, in the year 1582, a scaffolding suddenly gave way, and many of the spectators were killed, besides many others severely wounded and maimed. Several of the Clergy, and numerous writers, seized upon the moment, for exclaiming against the practice; and the Lord Mayor, (Sir Thomas Blanke,) in writing to the Lord Treasurer upon the occasion, observed, that it ' gave great reason to acknowledge the hand of God for breach of the Lord's Day,' and moved him to put an end to the practice. At Court, however, no notice was taken of that appeal. The office of Master of the Bears and Dogs was made patent by James $I$. who gave it to Alleyn, in whose time prize-fighting with 
swords, and the exhibitions of the drama, continued, as heretofore, to be joined with Bear-baiting at Paris Garden. Bear-baiting awaited the ascendancy of the Puritans, in the time of Charles I. for a temporary suppression, when it was prohibited, in common with all other theatrical entertainments. Restored by Charles II. Jorevin, a French traveller in England, in $16 \% 2$, was somewhat shocked at witnessing a bloody prize-fight at one of the Bear Gardens, between two professors of the sword: 'For my part,' says he, ' I should have had more pleasure in seeing the battle of the Bears and Dog's, which was fought the following day at the same theatre.' Locke, a few years later, mentions Bear-baiting and Prizes (prize-fights with swords,) at the Old and New Bear Gardens, among the diversions to which a stranger might be directed in London; but, in $1 \% 20$, fifty years after the visit of Jorevin, the sites of the Old Bear Garden and adjacent Falcon Tavern, the resort of IVilliam Shakspeare and his fellow-players, gave place to Bear-Garden Square, at present distinguished for Bradley's Iron-foundery and the Falcon Glass- 
house; and 'the Old Bear Garden,' says Strype, in Stowe, 'was removed to the other side of the water, which is more convenient for the butchers, and such like, who are taken with such rustic sports as the baiting of Bears and Bulls.' In 1750, even the new establishment disappeared; but more recently, a revival, upon the lowest scale, might be found, in some obscure part of Westminster. You have here, I believe, a sketch of the history of Bull-baiting in London, and as a national, and royal, and applauded sport in England."

"It has surprised me," said Miss Aston, " to hear the name of Shakspeare, in connexion either with Bear-baiting, or with the foot of Blackfriars Bridge!"

"Oh! the Surrey foot of Blackfriars Bridge, as my story has made appear, is classic ground, in English dramatic history; and, as to Shakspeare and the English drama, both of those sprang up, and even reached their splendour, in the very heart of Bull and Bear baiting! TheGlobe, the Hope, and other theatres, were all of them in or about Paris Garden; Shakspeare played, and Shakspeare's 
plays were played, with Bull and Bear baitings, and prize-fightings, between the acts; and the same spectators, with more or less modification, relished all the several exhibitions! Such is the human mind; such is the mixture of human affairs; such men have been our forefathers, and such will be our grandchildren!"

"I observe, however, that attention was paid to the comforts and enjoyments of the Bears, in the respect of the fields and ponds?"

" That is even the very point, in order to come to which, I have led myself and you into our history of Bear-baiting. It is, of course, a very gratifying consideration, that the English multitude, rich and poor, instead of being squeezed, as formerly, into foul and gloomy dens, called theatres, to find ' a good relief' in seeing a poor Bear 'shake hiz earz twyse or thryse, with the blud and the slaver about hiz fiznamy,' can now enjoy and feel enjoyment in the innocent view of the peaceable, unmolested condition of similar captives from mountain and forest, calmly placed before them, in fresh and freshening air, in the middle of shrubs, flowers, and 
parterres, and on a terrace commanding a view which might beautify and share praises with the 'marble halls of kings,' or, what is more, might vie with the scenery of the humblest cot or hamlet, or delight the most fastidious traveller! Doubtless, a contrast such as this, affords matter for gratifying consideration; but, at last, is enough accomplished? that is, in the matter of the Bears, Black, Brown, Yellow, and White, has the Zoological Society yet done justice to the beasts, to their visitors, or to itself? For the beasts, has it duly, kindly, and understandingly consulted their enjoyment, or even their health and preservation? For the visitors of the beasts, has it consulted, to the extent readily practicable, either their recreation or instruction? For itself, has it fully consulted the interests of its treasury?

"It is, as I suspect, certain, and (especially after the history which I have related) it can be no disparagement of any English public to make the avowal, that, acceptable as is the view of the Zoological Garden for its contents in general, the Monkeys and the Bears are the sturs of this Newest Bear 
Garden; and, in point of fact, "these our actors,' as the immortal Shakspeare might have said, need not the assistance of a further 'company' of Dogs, to offer to spectators a natural, an innocent, and a tranquil dramaa drama of real life-such as, day by day, would delight the eyes, and speak to the hearts of thousands. Give the Bears, as has been given to the Monkeys, no more than room; - give them a clear stage, and a fair stage, and their actions and manners would discover a variety as amusing as it would be pleasing and even instructive;a variety very distinguishable from that monotonous course of morement which, even such as it is, is so attractive to the multitude. Now, the Zoological Society, by accident, has fallen upon the discorery of a species of exhibition as lucrative to itself as it is estimable for the public; and there is no reason whatever why it should not pursue the route which chance has opened to it; nay, there is every reason, not more in the advancement of its own objects, than in a general regard for the pleasures and welfare of its fellow-citizens and countrymen, that it should yield itself to 
96 PLEASURES OF THE SPECTATORS.

the cultivation of an object which has offered thus spontaneously. But, to pursue that cultivation, it must enlarge and alter the sort of enclosure which it has allotted to its Bears; and it is by doing this that it will, at the same time, promote the health and long life of the Bears themselves, and manifest a humane consideration, not alone for their indulgence in their pleasures, but for the removal of their wants. The 'Bearwards' of old are their examples in the performance of these duties. It is true, that those had but in view the health, the strength, and the preservation of their cattle; but the Zoological Society, though with nobler motives to boot, are bound to consider even these. What I ask is, the removal of the poor animals from this dank pit, scarcely even to be dried either by wind or sun; and the enlargement of their sphere of action, and of popular entertainment, beyond the solitary motion of ascending and descending a ' ragged staff,' and sitting upon damp stones, receiving or expecting fruit or cates! But, to those ends, they should have an enclosure open to the sun and winds; and 
containing, besides a house, a bank and pond ; and, besides a ragged staff, a scaffold upon its top :- they should have, in short, a dwelling-place, in contrivance, between the yard of the Ostrich, or of the Kangaroos, and the houses, ponds, and surrounding banks, provided elsewhere for the Beaver and the Otter. Give them these, and give them a scaffold as well as a pole, and their own health and happiness, as well as the public pleasure and amusement, would be endlessly increased; a natural drama would be in constant exhibition; the most thoughtless spectator would be amused; and the reflecting and the beneficent would derive all that pleasure which is poured into the heart by the spectacle of the pleasure of those about us. 'I was by nature,' says Goldsmith, ' an admirer of happy human faces ; - he might have made the description general, and spoken of the nature of all about him; and it is not only of ' happy human faces,' but of all happy faces and figures whatever, that all men are admirers! The sight of pleasure is pleasing. We love the things that look happy; and when we love, 
we feel kindly. All feelings gather strength by exercise; and, to present a people with objects of love, is to cultivate their feelings of kindness, goodness, and virtue.

"What I propose, too, has nothing in it which is either impracticable or new ; and, indeed, its present omission might seem to impeach the knowledge, for we cannot doubt the humanity, of the members of the Society. To be enabled to bathe, is as needful to the Bear as to the Crane.

"In the Old and New Bear Gardens, at Bankside, ponds were prominent and indispensable appurtenances. In Baun's Plan, there appear three ponds between the two, besides a pond near each theatre; but a complete kennel, or establishment, for Bears, is thus described by the continental traveller, Brown, whose book, of the date of 1635 , contains an engraving of the 'Elector of Saxony his Bear Garden at Dresden,' in which is a large pond, with several Bears amusing themselves in it. In the book itself, he says, 'In the hunting-house, in the Old Town, are fifteen Bears, very well provided for and looked into. They have fountains and ponds to 
WHITE, OR POLAR BEAR.

wash themselves in, wherein they much delight; and near to the ponds are ragged posts or lrees, set for the Bears to climb up, and scaffolds made at the top, to sun and dry themselies, where they will also sleep, and come and go, as they are called by their keeper.'

"I I must add, that in the Garden of the Society, if the Black, Brown, and Yellow Bears ought to be accommodated with water, like the Beaver and the Otter, as well as with dwellings every way more commodious to themselves, and better adapted for the purposes of exhibition; eren still more ought the case of the White Bear to be taken into wise and merciful consideration!

" The habits of the White or Polar Bear are known to be eminently aquatic; and the climate which it is accustomed to is so cold, that the animal has never been seen southward of Iceland, even of which island it is not a native, but only arrives there occasionally, by accident and misfortune, and commonly in a state of famine and weakness, upon masses of floating ice. Yet this animal is here confined in a small den, with 
a southern aspect, and without water to resort to at its pleasure; and even this den is to make part of a house, which will be built over it against the winter, and in which the Polar Bear, and some eight or ten large animals beside, are to breathe one common and heated atmosphere; the Polar Bear being made the companion of the Lion, Tiger, Leopard, and other natives of the Torrid Zone! It is true that Bears, and the Polar Bear among the rest, bury themselves under the snow, and in similar sheltered situations during the winter; and, so far, it is possible, that the Society's Polar Bear may pass that season tolerably. It does not follow, however, that if this Bear is to be kept awake during the winter, by means of providing it with an artificial summer, it will thrive amid the same or greater heat than might be serviceable to it if asleep or hybernating; and how much better off, as well as how much more advantageously seen, the Polar Bear would really be, if treated something like the Otter or the Beaver, you will judge from the accounts given to us by naturalists. The Polar Bear (they 
tell us) suffers much from heat. One of the species, described by Professor Pallas, would not stay in its house during the winter, although it was at Crasnojarsk, in Siberia, where the climate is very cold; and, on the contrary, it seemed to have great pleasure in rolling itself in the snow. A Polar Bear, kept at the Museum of Natural History, at Paris, was found to suffer sererely from hot weather; and, throughout the year, its keepers were obliged to refresh it, by throwing sixty or seventy pails of water upon it daily. In truth, it is natural to it to be always in or near the water. Its prey is the Seal, Walrus, and fish, including the Whale; and all these it either seizes upon the rocks, shores, or ice, or pursues in the sea by swimming."

"But, must this Bear be fed wpon such food as you have mentioned?"

" That kept at Paris had only bread, of which it ate no more than six pounds a day, and yet grew very fat."

"I have read very affecting stories of the fondnes; oî the she White Bear for her young." 
102 SEALS, WALRUSES, AND WHALES.

"6 I know not whether it happens from the force of contrast upon the imagination of the beholders, or from an unperceived comparison made between the warm-blooded aquatic animals, and the different nature of the general inhabitants of the waters, or from a positive superiority in this respect, but all the Mammalia of the Northern shores and seas are celebrated for the strength and tenderness of their attachments ; sometimes of the parent to the young, sometimes of the young to the parent, sometimes of the male and female to each other, and, more than all, of each individual to the rest! The catalogue of these warm-hearted creatures of a cold region, includes the Bears, the Seals, the Walruses, the Sea-Horses, and the Manaties, or Sea-Cows. In the Whales, the Cachalots, the Grampuses, the Dolphins, the Porpoises, though the same virtues are probably inherent, the forms of the animals themselves, and the element which they exclusively inhabit, make them less discoverable to the human eye; and, so universally diffused are the traits of animal character, of the kind now under our contemplation, that it would be needful to 
possess a very ample acquaintance with the habits and affections of all the several species, before we could safely venture to pronounce which surpasses the other, in feelings of tenderness and love. The singularity in nature is, not where these things are found, but where they are wanting! Waller, in his poem of the Summer Islands, has put into verse a real anecdote, illustrative of the maternal tenderness of these creatures for their offspring. A Whale and her cub had got into an arm of the sea, where, by the desertion of the tide, they were left almost incapable of retreat. The people upon the shore soon saw their situation, and came down upon them in boats, with such weapons as the occasion permitted. The Whales made continual efforts to escape, but were wounded upon every side, and soon dyed the water with their blood. At length, the mother, by superior strength, forced her way through the shallows, and found herself in deep water, and therefore free. But, though now in safety herself, she saw her young one still behind, and therefore plunged her way lack again, to succour it, in the face of all the 
danger impending. The story ends with poetical justice; for the tide, at length, came in, and enabled both to escape from their enemies, though not without receiving wounds so long as they were within reach. In another example, some fishers having struck one of two Whales, a male and female, which were in company, the wounded fish offered a long and powerful resistance to its destroyers, in the course of which it struck down a boat, containing three men, with a single blow of its tail. The other Whale remained with its companion, lending all the assistance in its power; till, at length, the one which was struck died under the number of its wounds, while its faithful associate, incapable of forsaking it, stretched itself, with the most mournful bellowing, upon the dead Whale, and patiently endured the blows that took away its own existence.

"The female Whale carries her young with her wherever she goes, and when hardest pursued, keeps it supported between her fins; eren when wourded, she still clasps her young one; and, when she plunges, to 
fly the danger, takes it with her to the bottom, but rises sooner than usual, to give it breath again.

"While listening, however, to these and endless similar details, we are never to forget, that we are speaking of Mammalia, though inhabitants of the ocean; that Whales have warm blood, and suckle their young, and have the same animal nature with the Elephant, the Ox, the Dog, and the Cat, in all of which similar examples of tenderness are so familiar as to excite no surprise ; and that, in the several kinds of Whales, we have to do with a different class of animals than that of those cold-blooded and oviparous ones which are Fishes of the ordinary kind.

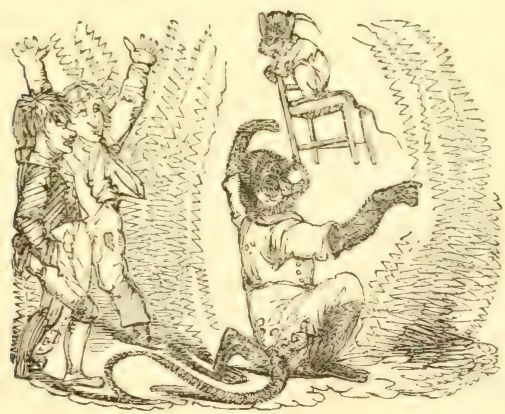




\title{
ORIGINAI, POETRY.
}

\section{TIE CAT, THE OLD MOUSE, AND THE YOUNG MOUSE.}

\author{
A FADLF:
}

\section{From the German.}

$$
\text { CAT. }
$$

$\mathrm{O}_{\mathrm{H}}$ ! thou pretty little creature,

How beautiful in every feature,

Come a little nearer me!

Oh! I love thee passing well,

More than I have words to tell-

Let me give a kiss to thee !

$$
\text { OLD MOUSE. }
$$

My child! I beg thee not to go-

$$
\text { CAT. }
$$

Look, and behold this tempting show !

These nuts and cakes shall all be thineAll for a kiss !

YOUNG MOUSE.

$$
\text { O nother, hear ! }
$$

How kind she speaks-what dainty cheer?

I go.- 
CAT, OLD MOUSE, AND YOUNG MOUSE. 10\%

$$
\text { OID MOUSE. }
$$

Take this advice of mine.

$$
\text { C.AT. }
$$

See this delicious gingerbread!-

This shall be thine, for what I said;

And all these sugar-plums so sweet!

YOUNG MOUSE.

What shall I do? Oh, let me go!

$$
\text { OLD MOUSE. }
$$

My child, I say, do not do so !

$$
\text { YOUNG MOUSE. }
$$

What evil can we meet?

See how nice these things appear !

$$
\text { CAT. }
$$

You little rogue! come here! come here!

$$
\text { YOUNG MOUSE. }
$$

Oh, Mnther, help! Oh, give me aid ! She tears me! Oh, how I'm betrayed!

OLD MOUSE.

'Tis now too late;-in vain for help you call; He that won't take advice, must bear with all! 
RATEL AND MOROC, OR BEE-CUCKOO.

IATEL. - INDIAN BADGET. - BEE-CLCKOO, HONEXGUIDE, HONEY-BIRD, OR MOROC.

"Is the animal which they show us here as the Ratel, the Ratel properly so called ?"

Such was the question which one of our usual party proposed, after the animal itself, by a display of habits as amiable as they were singular, had interested them and other spectators, to an unusual degree, in its observation and history. In the hutch, or cage, immediately adjoining its own, but entirely hidden from its view, is a Coatimandi, an animal of something of its own size, figure, and habits, but yet of very different colour and appearance, and from another part of the world; and when spectators give the Ratel (so called) fruit or biscuits, it immediately picks them up with the greatest eagerness and apparent solicitude, and with 

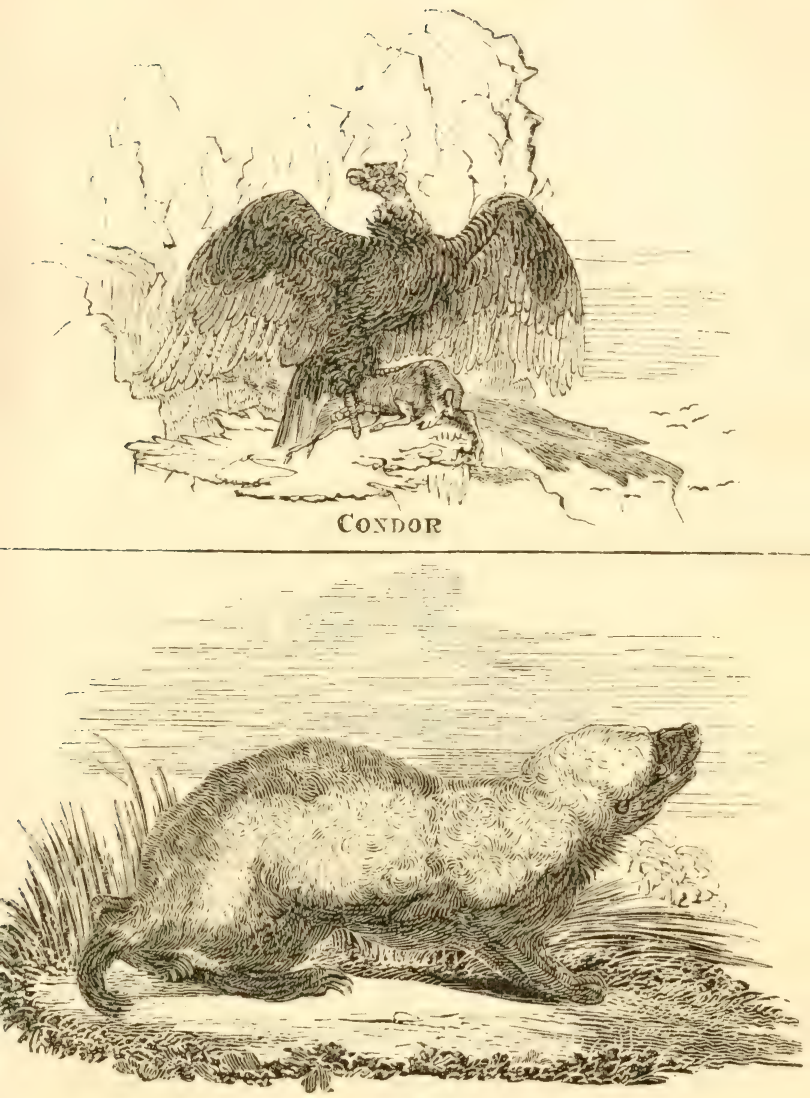

R.TEL.

l'ublished by Marsh and Miller, Oxford-street, and Colnaghi, Cockspur-street. 

THE RATEL AND COATIMONDI. 109

its great claws, puts them through the bars next to its neighbour, bending its paw to give it the utmost strength, and waiting till the equally great claws of the Coatimondi have either managed to secure some part of the prize, or till the whole, clawed to pieces, has fallen to the ground, and become lost to both. The manner and look of the Ratel, in the mean time, are the most striking and expressive imaginable. The Coatimondi appears to receive the gift like a mere animal ; but the Ratel has the air of a patron or benefactor, and seems acutely alive to the success of his efforts in behalf of the Coatimondi. The action is precisely the same, as if one neighbour out of his own window, were using the fullest bodily exertion to convey to the adjoining window of another neighbour, a loaf, or a basket of fruit, and patiently and earnestly striving and holding the gift, till his neighbour, whom he could not see, had securely grasped it. What increases the appearance of kindness upon the part of the Ratel, is the fact, that the food is of a kind quite as agreeable to itself as to the Coatimondi, since, after many gifts to the 
110 THE RATEL AND COATIMONDI.

latter, it will take a part of what is given it to itsclf. But the Ratel is a female. Can it be, then, that she thinks she is feeding a young Ratel, or sharing her meal with her consort? In any case, it is clcar that the Coatimondi has no smell which can be offensive to the Ratel, or imply some very discordant species of animal. The long and powerful claws upon the fore-feet of the Coatimondi are exactly of a pattern with those of the Ratel. For the rest, the Coatimondi is in look plain; for its brown colour, and want of every attractive peculiarity, give it little chance of commanding from strangers those attentions which fall to the Ratel. The party were the more struck with this action of the Ratel, (so called) because the ingenious author of a recent description of it, has particularly excepted mildness of temper toward its fellow animals from among the number of its virtues:- ${ }^{66}$ As far," says this writer, " as its manners have yet bcen developed, it appears to be, with regard to man at least, one of the most playful and good-tempered of beasts, soliciting the attention of almost 
érery visitor, by throwing its clumsy body into a variety of antic postures, and, when noticed, tumbling head orer heels with every symptom of delight. But, toward animals, it exhibits no such mildness of temper; and it is curious to observe the Cat-like eagerness with which it watches the motions of any of the smaller among them that happen to pass before its den, and the instinctive diead manifested by the latter on perceiving it. Its food is of a mixud nature, consisting, like that of the Bears, and other less carnivorous beasts, of bread and milk in the morning, and flesh in the latter part of the day." *

" I will not now enter into my reasoms for concluding that the specimens, either living or dead, of the Zoological Society, are not specimens of the Ratel, but of the animal properly distinguished by Pemmant by the name of Indian Badger; for I know that, though these would amuse you by showing the respective figures and habits of those two very distinguishable animals, you will be

* Garden and Menagerie of the Zoological Society delineated, p. 20. 
still better pleased to hear of the little bird which is so useful to the Hottentots, and to the real Ratel.

"The writer whom I last mentioned, quoting, though with partial incredulity as before, relates, that Bees furnish the Ratel with his principal, if not his only, means of subsistence. These insects are accustomed to take up their abode in holes in the earth, formed by various burrowing quadrupeds; and the Ratel is endowed with peculiar sagacity for discovering their nests, which it undermines with its powerful claws, in order to feast upon the honey contained in them.* Aware that sun-set is the period at which the Bees return to their homes, it chooses that time for making its observations, which are conducted in a very curious manner. Seated upon the ground, with one of its paws raised, so as to shade from its eyes the rays of the declining sun, it peers cautiously on either side of this singular kind of parasol, until it perceives a number of Bees flying in the

" "A particular faculty," says another writer, " of discovering and attacking them within their intrenchments." 
same direction. These it carefully marks, and follows in their track, until it has safely lodged them in their nest, which it immediately commences pillaging." "*

Our author next recites an account of the assistance which the Ratel sometimes receives from a little bird, which has been called Cuculus Indicator, and Bee-Cuckoo, "Honeyguide;" according to SPARRMAN, Honeybird, Honey-guide; and by the Hottentots, Moroc,-an equal guide to the Hottentot and colonists; and which, by itself, contributes to bring into view, that the Ratel hunts by

* Perhaps the subjoined and older description is still more pieturesque :- " Is a man placed at the mast-head, can most easily descry a sail or land at a great distance in the erening, so, probahly, this time of the day is most convenient for the Ratel to look out for his food. Towards sun-set he issties from his hole. Near this he sits upright, and holds one of his paws before his eyes, in order to modify the rays of the sun, and, at the same time, to procure a distinct view of the olject of his pursuit ; and when, in consequence of peering thus on each side his paw, olyosite to the sun, he sees any Bees fly, he knows that they are proceeding straight to their habitation, and consequently takes care to kcep in the same direition, in order to find them." 
day, and not by night. But upon this branch of the subject it will be agreeable to introduce the description of a more recent pen than Sparrman's :- "Two miles further, we came to a shoal, [in the Great Fish river,] and satisfied ourselves that our voyage must end here; and we resolved on returning to a beautiful spot which we had selected for our repast, and where we amused ourselves with exploring every part: we had no paths but those formed by the Baboons. At the end of one we discovered a rude, but very ingenious scaffolding, made by the Hottentots, to obtain honey from the hives. The rock overhung its base so much, that very great labour and skill were required, and risk incurred, in fixing and tying, with strips of bark, the poles and branches of trees. Their reward may literally be said to be sweet! The manner of finding it [the honey] is very singular, as related to us by one of our party, who had accompanied a Hottentot in search of some. The Hottentot went to a place that he thought likely to contain hives, and immediately whistled, with a sort of call that the Honey-bird, or Indicator, is accustomed 
to, when the little feathered attendant made its appearance, chirping loudly, and hovering about them : it then flew forward, still chirping, and watching to see if they followed. It tried twice to lead them across a kloof, * flying back, and again forward, to entice them to follow: they, however, not liking to go that way, and the Hottentot still continuing to whistle the call, the bird at length flew back, and led another way, still watching and chirping to them to follow him, which they now did, and very soon it hovered over a place in the rock, where, on searching, they found a hive full of honey: the bird immediately perched in a bush orer them, and waited patiently till they had taken the honey, when it flew down, and took possession of the rest, and eat what was left for it.

"The Honey-bird is rather larger than a Sparrow, with brown feathers. The quantity of honey taken every year is immense, and its flavour rery delicious. The Bees seldom or ever sting, if they are not hurt. The Hottentot is rery particular in his manner of leaving the honey for the bird, as he * Cleft, or ravine. 


\section{THE HOTTENTOTS.-RATEL.}

says it will then remember him, and lead him another time, in preference to any other person. When the bird has eaten the honey, the young Bees are carefully closed up with stones, to prevent the Ratel (a kind of Badger) from taking them out; and, as there are always a quantity of flowers, the Bees never want nourishment." **

"To this bird," says another narrator, " is ascribed the faculty of discovering and pointing out to man, and to the quadruped called the Ratel, the nests of Wild Bees. It is itself exceedingly fond both of honey and of the Bee-magots. The morning and evening are its principal meal-times, at least it is then that it shows the greatest inclination to come forth, and with a grating cry of ' Cheer ! cheer ! cheer!' to excite the attention of the Ratel, as well as of the Hottentots and colonists. Somebody, then, repairs to the place whence the sound proceeds, when the bird, continually repeating its cry of 'Cheer! cheer! cheer !' flies on slowly, and, by degrees, towards the quarter where the

* "Scenes aidà Occurrences in Albany," \&e. chap. iii. 1'. 52 
swarm of Bees has taken up its abode. The persons thus invited, accordingly, follow, taking care, at the same time, not to frighten their guide by any unusual noise, but rather to answer it, now and then, by a soft whistle, by way of letting the bird know that its call is attended to. When the Bees'-nest is at some distance, the bird often makes long stages or flights, waiting for its sporting companions between each flight, and calling to them again to come on; but it flies to shorter distances, and repeats its cry more frequently, and with greater earnestness, in proportion as they approach nearer to the nest. When, sometimes, the bird, in consequence of its greater impatience, has got too far a-head of its followers, but particularly when, on account of the unevenness of the ground, they have not been able to keep pace with it, it has flown back to meet them, and with still greater impatience, upbraiding them, as it were, for being so tardy. When it comes to the Bees'-nest, whether built in the cleft of a rock, or in a hollow tree, or in some cavity of the earth, it hovers over the spot for a few seconds; after which, it sits in 
silence, and for the most part concealed, in some neighbouring tree or bush, in expectation of what may happen, and with a view of receiving its share of the booty." It is added, that the hunters, by way of acknowledgment, usually leave to the bird a considerable share of that part of the comb on which the young Bees are hatching, and which is probably to it the most acceptable morsel; a remark which, if made upon good foundation, contributes to make it appear probable, that both with the Honey-bird and the Patel, Bec-eating, as well, at least, as honcy-eating, is a principal olject! Dr. Sparrman says, that a nest, which was shown to him as belonging to this bird, was composed of slender filaments of bark, woren together in the form of a bottle; the neck hung downward, and a string, in an arched shape, was suspended across the opcning, fastened at the two ends, perhaps for the bird to perch upon. If the Bee-Cuckoo, so called, is really of the Cuckoo genus, this elaborate architecture of its nest makes a strong contrast with the practice of the Cuckoo known in England, and which is scarcely believed ever to build any! The 
Bee-Cuclioo, as it is said, does not differ much in appearance from the Common Sparrow, except that it is somewhat larger, of a lighter colour, and has a yellow spot upen each shoulder; the feathers of its tail are dashed with white.

Upon the value, too, of Bee and honeyeating animals of all linds (and there are many, with reference to the general economy of nature, I inay remark, the north of Africa more especially, and in the parts of Asia adjacent, the abundance of honey is not without the accompaniment of much human suffering from Bees. In the parts recently visited by Messrs. Denham and Clapperton, it was found that the natives were accustomed to build their houses, at least, as artificially and intricately, by way of fortification against Bees, as the Esquimaux build their snow-houses for defence against cold; and the Hebrew Scriptures contain several passages, from which it appears, that in $\mathrm{Pa}$ lestine, the molestations of Bees were thought so terrible as to afford a simile for the situation of a man, or of a people the most fiercely or the most numerously beset with 
enemies. "All nations," says David, " con1passed me about; but in the name of the Lord I will destroy them. They compassed me about like Bees ;"- - and Moses, reminding the Israelites of their defeat beneath Mount Seir, employs the same mode of expression :- "And the Amorites, which dwell in the mountain, came out against you, and chased you as Bees do." So that, as you may think for yourselves, if we have less honey in our more northern regions, than falls to the share of the more southern, we are less troubled, from the same cause, with the plague of Bees! 


\section{ORIGINAL POETRY.}

\section{TO A DOVE, AT SEA.}

BY HENRY J. BRADFIELD, ESQ.

SWEET bird of love! here take thy rest,

And smooth thy wildly ruffled wing;

Here, if thy gentle timid breast

Be captive to lone sorrowing, With the pale hues of lingering day, Let peace dispel those cares away!

Fair innocent! around, on high,

Fleet lightning darts its melting ray;

Loud thunders rock the shrouded sky,

And darkly roll beneath! Oh, stay,

And on my heaving breast recline ;

I would not hurt one plume of thine.

Perchance, thou mourn'st some loved, lost mate, And from the fountain's wanton play,

Or shadowy groves, disconsolate,

Thou wanderest from the woods away:

Now that thy own fair bride is gone, Thou fain wouldst live, and die, alone! 
Fond, faithful bird! could I inherit Thy gentle form, to roam as thee; Or unseen, like aërial spirit, Throw off this cold mortalityEv'n in this hour, my bounding soul Should be absolved from earth's control. Softly sleep, thou beauteous Dove! Pillow'd on my heart, repose ; Till, rising toward his throne above, The sun, in glorious splendour, throws His beams around! then borne on wing, I 'll leave thee to thy wandering. 



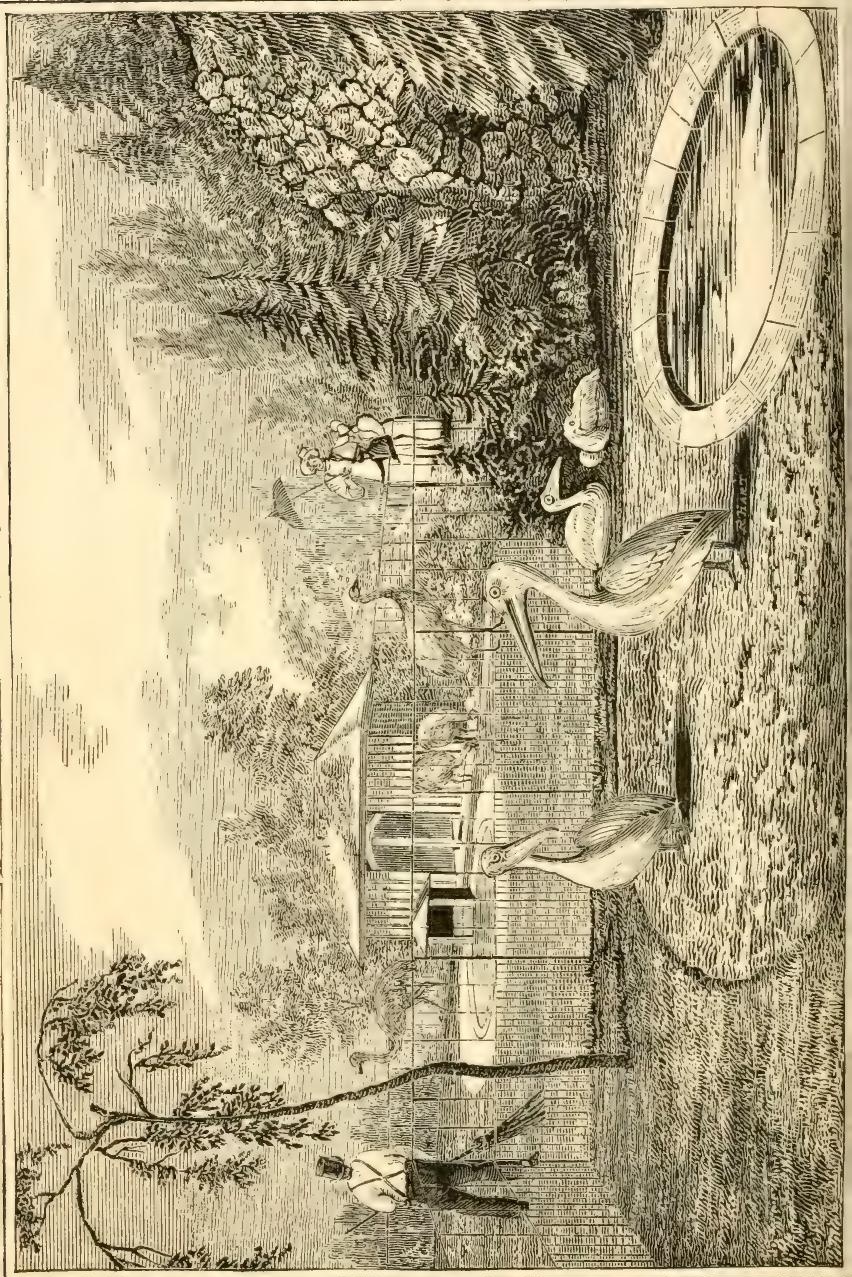




\section{ENCLOSURE FOR PELICANS.}

PELICANS.-GREAT WHITE PELICAN, a PELICAN OF THE WILDERNESS.-CARE FOR ITS OFFSPRING, AND FOIR ITS FELLOW-PELICANS.-BARBAROUS LSAGE IN MLXICO, FOCXDED UPON THIS DISPOSITION OF THE PELICAN.- PELICAN'S TAMEABLENESS. - LOVE OF IIUMAN SOCIETI, AND OF MUSIC, VOCAL AND INSTRUMENTAL. - SWAN.-SEVERAL SPECIES OF PELICAN.-RED-BACKED, GANNET, OR SOLAN GOOSE AND BOOBY.-PIRATE, FRIGATE, OR MAN-OF-WAR BIRD. -Albatross, or alCATRAZ.-PENGUIN.-TROPICAL SEAS AND SEA-BIRDS.-IRREGULAR SONNET TO THE SEA-BIRD.

Passing from the Large Aviaries, and approaching the Enclosure for Pelicans, Mr. Dartmouth observed, that the Great White Pelican, the single species to which the two pair, old and young, contained in that Enclosure, are supposed to belong, is not peculiar, as usually represented, to Asia and Africa, but abounds also in North America. The truth is, that in all the warmer 
portions of the north of the two continents, the Pelican takes the place of the Swan, to which latter bird, more than to any other, it bears resemblance. You will judge for yourselves, however, how much less beautiful than the Swan, the Pelican discovers itself to the eye; while, at the same time, it surpasses it in size. While the Swan, nevertheless, is eminent for the beauty of its form and motion, the Pelican has moral virtues which seem to surpass those that have been hitherto recorded of the Swan; and which at once explain and justify many, at least, of the notions which antiquity has bequeathed to us of the former bird; for the ancients seem to have observed it well, while the moderns uniformly speak of it without sufficient reflection. The Pelican, like so many other animals, is found to be not only an attentive nurse of its young, but a kind neighbour to its fellow Pelicans. In Mexico, advantage is taken of this latter part of its character, in order to rob it of the large supplies of fish which it brings from the water in the pouch attached to its bill. In order to obtain a supply of fish, the wing of a live Pelican is 
THE PELICAN'S CARE OF ITS YOUNG. 125

cruelly broken, and the bird tied to a tree. The cries of the miserable bird, and the maimed and helpless condition it appears in, bring a number of its species to its aid; and each of these latter throw out to it a portion of the fish which they had caught for themselves, or were carrying to their young.

You will easily understand, that the remarkable manner in which the Pelican feeds its young with fish, sometimes broken or prepared, from the enormous pouch, (for such, especially when filled, it is,) which overhangs its breast, is the origin of the fabulous exaggeration, that it feeds them by piercing its breast for blood.

Lebat informs us, that he caught two young Pelicans, and tied them by the leg to a post stuck into the ground; upon which, for several successive days, one of the parents regularly came to feed them, remained with them the greater part of the day, and passed the night upon the branch of a tree that hung over them; and the result was, that all the three birds became so familiar as to suffer themselves to be handled. The young ones always took the fish offered to 
126 THE DUKE OF BAVARIA'S PELICAN.

them, stored it in their bags or pouches, and swallowed it at leisure; and this is similar to the practice of the green birds, which fill their pouches while fishing, and then come on shore to eat it. Through this part of their habits, Pelicans have been domesticated, and taught to bring home to their masters the fish that they have taken, of which a part is left to themselves. A similar practice, much adopted in China, with respect to the Cormorant, or Sea-crow, thence called the Fishing Cormorant, has led to that confusion of the manner and histories of the two birds, of which I have already made mention.

The Pelican, according to Faber, is not destitute of even other qualifications. One which lived for forty years, at the court of the Duke of Bavaria, was exceedingly sensitive and intelligent. It was much delighted with company, and loved to be talked to, and to hear music, both vocal and instrumental. "It would willingly stand," says that author, " by those that sung, or that sounded a trumpet; and stretching out its head, and turning its car to the music, listen very at- 
tentively to its harmony, though its own voice was little pleasanter than the braying of an ass." The Emperor Maximilian had a tame Pelican which always attended his army on its march.

The Pelican, like every other creature, can also be sportive. One kept tame at the Cape of Good Hope, used to play with a great Dog, whose head she often took into her bill and pouch. As to the size of these, when fully extended, it is averred, not only that a man's head may enter and be hidden in them, but that a man has been seen to put his whole leg, to the knee, boot and all, and perfectly hide it.

Considering all that we now know of the habits and virtues of the Pelican, it might seem extraordinary, (if we had not the living bird before us, of which the appearance indicates so much of what I am going to qualify,) that the name of this bird should so continually recur in the Hebrew Scriptures as an image of solitude and melancholy, Ec. accompanied, in all modern books of natural history, with reproaches of gluttony, voracity, stupidity, and heaviness. But the 
Pelican is a ruminating bird. It ranges long and widely in its pursuit of its prey, and then returns to a rock, or to a tree, where, if it has no young to feed, or no kindred bird to help, it sits solitary and heavily, while eating and digesting its food. We see, in this manner, that it is easy to represent the Pelican under opposite characters, each equally true, and equally occasional; and we see, also, how dangerous it usually is to take up general notions from particular circumstances. The same bird or man, of whom, at one moment, it may consist with truth to say one thing, is, at another moment, or under other circumstances, entitled to quite another reputation. Suppose, for example, that our friend George is sometimes sleepy; does it therefore follow that we should say that George is a sleepy fellow; that is, that he is always asleep?

There are other species of the Pelican than this, particularly the Red-backed, the Booby, and that which is otherwise called the Gannet, or Solan, or Island Goose ;* but

* Pelicanus Bassanus. Linn. - Fou de Bassan. BuFfon. 
I am not so well satisfied to include in the number, either the Cormorant, or the Seabird, which is sometimes called the Frigate Pelican. All the Pelicans have pouches, of greater or less dimensions, for carrying fish ; and the large size of the pouch of the Great Pelican may seem to imply that it is destined to make a wider circuit in pursuit of its prey, than those of which the pouches are smaller.

"Fou," or Fool, is a name given by the French sailors, and Booby, by the English, to sereral sea-birds, exclusive of the Booby Pelican, on account of their silly aspect, and habit of shaking their heads and shirering, when they alight on the yards or rigging of vessels, where they often suffer themselves to be taken with the hand. But the Booby Pelican is also remarked, not for silliness, by the deficiency of bodily strength, which obliges it to submit to the plunder of the bird that is variously called the Pirate, Frigate, and Man-of-war Bird. The habit of the Pelicans to keep their prey for some time in their pouches, instead of immediately swallowing it, appears to expose them to its loss; for it is not man alone that has discovered the art of 
deriving a profit from their industry. According to Catesby, the Pirate subsists entirely upon the spoils of others, and particularly the Booby. As soon as the former perceives that the latter has caught a fish, he flies furiously against it, and obliges it to dive under water for safety. The Piratc, not being able to follow it there, hovers above till the Booby is obliged to rise to the surface for breath, when it attacks it again, and ends by compelling it to surrender its fish; and the unfortunate Booby has no remedy left but to go fishing again, and take his chance of keeping his booty to himself. Similar histories are given of the treatment of the Booby by a bird which Leguet calls a Frigate, and Dampier, a Man-of-War Bird.

"Why, that," said Jane," is just the way that I have seen one of the Monkeys in the Garden serve a lesser Monkey, his companion. Fxactly opposite to the kind and patronizing air of the Indian Badger toward his neighbour, the Coatimondi, the larger Monkey, when the lesser has a nut or any thing given to it, seizes it by the nape of the 
neck, and holds it fast, though without any violence, raises the lip, first upon one side, and then upon the other, to look in its cheek, or between its teeth, for the prize; and, however loudly the lesser monkey may scream, never fails to get the nut at last!"

"Such, my dear, is the way of the world, whether human or animal; but, by the way, I should much like to see our Indian Badger in a cage, separated from his Coatimondi only by bars, and to know how he would behave to it if he could see it, and had constant intercourse? Going back, however, to our Pirate, Frigate, or Man-of-War Bird, I shall tell you, that I suspect those names and their history belong to a species of Albatross, or Alcatraz, the largest description of Gull, and not to any Pelican. Of these latter birds, the Wandering Albatross* is the largest, and of that species you have a specimen at the Museum in Bruton-street, and an engraved figure in the Catalogue. The size of this species across the wings, is nine

* Albatross. Buffox. - Wandering Albatross, Man-of-War Bird. Alrin. - Diomedia exulans. LINN. 
132 THE ALBATROSS AND PENGUIN.

feet, but ten feet is sometimes the measure. The Albatross scours all the seas, from Kantschatka to the Line, and is every where the plunderer of the Boobies and other fishing-birds, and a fierce and powerful mountain-bird of prey; but, though this is its true character, it lives upon the kindest terms with the Penguin, unless, indeed, there is a general confusion of the Albatross with the Pelican, or unless both Pelican and Albatross live equally well with the Penguin; for what one writer relates of the Penguin and Albatross, another refers to the Penguin and the Pelican. The Penguin is a seabird which occupies, in the southern parts of the world, the place of the Hawk in the northern. 'The Albatross,' says Goldsmith, ' seems to have a peculiar affection for the Penguin, and a pleasure in its society. They are always seen to choose the same places for breeding; some distant, uninhabited island, where the ground slants to the sea, as the Penguin is not formed either for flying or climbing. In such places, their nests are seen together, as if they stood in need of mutual assistance and protection. Captain 
Hunt, who for some time commanded at our settlement upon Falkland Islands, assures me that he was often amazed at the union preserved between these birds, and the regularity with which they built together. In that bleak and desolate spot, where the birds had long continued undisturbed possessors, and no way dreaded the encroachment of men, they seemed to make their abode as comfortable as they expected it to be lasting. They were seen to build with an amazing degree of uniformity, their nests covering fields by thousands, and resembling a regular plantation. In the middle, on high, the Albatross raised its nests, on heath, sticks, and long grass, about two feet above the surface: round this, the Penguins made their own settlements, rather in holes in the ground, and most usually eight Penguins to one Albatross.' Other accounts, as I have intimated, call the companions of the Penguins, of Falkland Islands, by the name of Pelicans.

"Except for some particulars concerning the Albatross, in which sober history does not bear out the tender painting of the poet, 
the following lines, from the 'Pelican Island,' might seem to bring to our imagination the scene to which our naturalists refer :

"Throughout this commonwealth of sea-sprung lands,

Life kindled in ten thousand happy forms, Earth, air, and ocean were all full of life. Still highest in the rank of being, soar'd The fowls amphibious, and the inland tribes Of dainty plumage or melodious song. In gaudy robes of many-colour'd patches, The parrots swung like blossoms on the trees, While their harsh voices undeceived the ear.

More delicately pencill'd, finer drawn In shape and lineament; too exquisite For gross delights; the Birds of Paradise Floated aloof, as though they lived on air, And were the orient progeny of heaven, Or spirits made perfect veil'd in shining raiment. From flower to flower, where wild bees flew and sung,

As countless, small, and musical as they, Showers of bright humming birds came down, and plied

The same ambrosial task, with slender bill Extracting honey, hidden in those bells, Whose richest blooms grew pale beneath the blaze Of twinkling winglets hovering o'er their petals, 
Brilliant as raindrops, when the western sun Sees his own miniature of beams in each.

"High on the cliffs, down on the shelly reef, Or gliding like a silver-shaded cloud 'Through the blue heaven, the mighty albatross Inhaled the breezes, sought his humble food, Or, where his kindred like a flock reposed, Without a shepherd, on the grassy downs, Smooth'd his white fleece, and slumber'd in their midst."

An old writer gives a striking picture of the habits of the Albatross, including that of the Tropical seas and their sea-birds. "The Alcatraz," says he, "is one of the most fierce and formidable of the aquatic tribe, not only living upon fish, but also such small waterfowl as it can take by surprise. It preys, as all the Gull-kind do, upon the living, and chicfiy pursues the Flying-fish, that are forced from the sea by the Dolphins. The ocean, in that part of the world, presents a very different appearance from the seas with which we are surrounded. In our seas, we see nothing but a dreary expanse, ruffled by the winds, and seemingly forsaken by every class of animated nature. But the Tropical 
seas, and the distant south latitudes beyond them, are all alive with birds and fishes, pursuing and purstied. Every various species of the Gull-kind are there seen hovering on the wing, at a thousand miles distance from the shore. The flying-fish are every moment rising to escape from their pursuers of the deep, only to encounter equal dangers in the air. Just as they rise, the Dolphin is seen to dart after them, but generally in vain; the Gull has more frequent success, and often takes them at their rise, while the Alcatraz pursues the Gull, and obliges it to relinquish its prey; so that the whole horizon presents but one living picture of rapacity and evasion."

"That picture of the Tropical seas is very vivid," said the Admiral, to-day, who had again joined the party; " but I think its contrast with the other seas is attempted to be made too strong. The Tropical seas are exuberantly supplied with living things, but there are no seas upon which life is not discovered in more or less profusion. Sea-birds are everywhere upon the waters. I have in my pocket a copy of an irregular 
sonnet addressed to one, by a friend, which was written upon the deck of a vessel one moming, upon the Aliantic, after a stormy night, and when the waves were rolling as hugely as the sun was shining brightly, but in a latitude on this side the Tropic :-

\section{TO THE SEA-BIRD.}

IY EDWARD AUGUSTUS KENDALL, ESQ.

Pleased I beheld thee, rover of the deep,

That brav'st the terrors of this raging world ; And follow, still, with curious eye, thy sweep

O'er emerald waves, vith snowy heads y-curl'd ;

Pleased I behold thee o'er the expanse ride, Now poised aloft, amid the lurid skies; Descending, now, the watery valleys wide,

Now rising slow, as slow the billows rise :

Pleased I behold thee! and think blest it were, Like thee, the dark seas dauntless to explore: Like thee, to toil unwearied, and to dare;

Nor, with a coward's haste, to seek the shore:

Tempt, while I please, the fortune of the day, Then spread the wing, and toil, at will, away!

"While the sea-birds," resumed tise Admiral, "prey upon fishes from above, there are 
abundance of fishes of prey to feed upon their fellow-fishes below. The White Shark is one of the most rapacious; but it is remarkable, that these fishes of prey interfere so little with birds of prey, that, though famous for swallowing almost any thing, they absolutely refuse to touch any bird at all. A hen, dead or alive, thrown overboard at sea, may float in perfect safety from that fish; and the sailors have a proverb, ' The Shark flees from feather." "'

"The Shark is of enormous size?"

"There is an entire confusion in the ordinary natural histories of the Shark, through the mixture of the rapacity of one species with the dimensions of another. The Great Shark, Basking Shark, or Sun-fish, feeds upon marine plants, and some of the species of the medusæ; or, in general, like the Whale. Like the Common Whale, the Great Shark can swallow nothing of magnitude, and has a bony apparatus in the mouth, shorter, but like that of the Whale, to retain, as by a sieve, the small bodies which compose its food. The White Shark, or Common Shark, which is the rapacious 
fish, is of very moderate dimensions. Rapacious and terrible, however, as that fish is, it is equally remarkable for being met fearlessly and without injury by man, under various circumstances. In the South Sea Islands, men and women bathe among White Sharks without apprehension; in the West Indies, Negroes arm themselves with knives, and meet and destroy them: but one of the most curious examples of human triumph over a Shark was lately witnessed in the river Ganges, at Calcutta, in the person of a Hindoo boatman of the inland country, whose success was obtained by his personal strength and dexterity alone, and consisted only in enthralling the shark with a rope by means of which it was then dragged on shore.

" 'I was walking,' says the eye-witness, ' upon the bank of the river, at the time when some up-country boats were delivering their cargoes. A considerable number of coolies* were employed on shore in the work, all of whom I saw running away in apparent trepidation from the edge of the 
water; retuming again, as if eager, yet afraid, to approach some object; and again returning as before. I found, on inquiry, that the cause of all this strange perturbation was the appearance of a large and strange-looking fish, swimming close to the bank, and almost in the midst of the boats. Hastening to the spot, I perceived a huge Shark sailing along,-now near the surface of the water, and now sinking down, apparently in pursuit of his prey. At this moment, an up-country Native, standing upon the Choppah roof of one of the boats, with a rope in his hand, which he was slowly coiling up, surveyed the Shark's notions with a look that evidently indicated a serious intention of encountering it in its own element. Holding, in one hand, the rope, on which he made a sort of running-knot, and stretching out the other arm as if already in the act of swimming, he stood in an attitude truly picturesque, waiting the re-appearance of the Shark. At about six or eight yards from the boat, the fish rose near the surface, when the Native instantly plunged into the water a short distance from its very jaws. The Shark 
immediately turned round, and swam slowly toward the man, who, in his turn, nothing daunted, struck out the arm that was at liberty, and approached his foe. When within a foot or two of the Shark, the native dived beneath him, the animal going down almost at the same instant. The bold assailant in this most frightful contest soon re-appeared on the opposite side of the Shark, swimming fearlessly with the hand he had at liberty, and holding the rope behind his back with the other. The Shark, which had also, by this time, made his appearance, again immediately swam toward him; and while the animal was apparently in the act of lifting himself over the lower part of the Native's body, that he might scize upon his prey, the man, making a strong effort, threw himself up perpendicularly, and went down with his feet foremost; the Shark following him so completely at the same moment, that I was fully impressed with the idea, that they had gone down grappling together. As far as I could judge, they remained nearly twenty seconds out of sight, while I stood in breathless 
anxiety, and, I may add, horror, waiting the result of this fearful encounter. Suddenly, the Native made his re-appearance, holding up both his hands over his head, and calling out, with a voice that proclaimed the victory he had won while underneath the waves, 'Tan-tan!' The people in the boat were all prepared; the rope was instantly drawn tight; and the struggling victim, lashing the water in his wrath, was dragged to the shore and despatched. When measured, his length was found to be six feet nine inches. The Native who achieved this intrepid and dangerous exploit was no otherwise hurt than by a cut on the left arm, evidently inflicted by the tail or by one of the fins of the Shark.'

"As to the really Great, or Basking" Shark," added the Admiral, "it is certainly the real Craken of the old Norwegian writers. However extravagantly misrepresented, the true histery of the Basking Shark agrees with the fabulous history of the Craken in all its credible and essential particulars." 



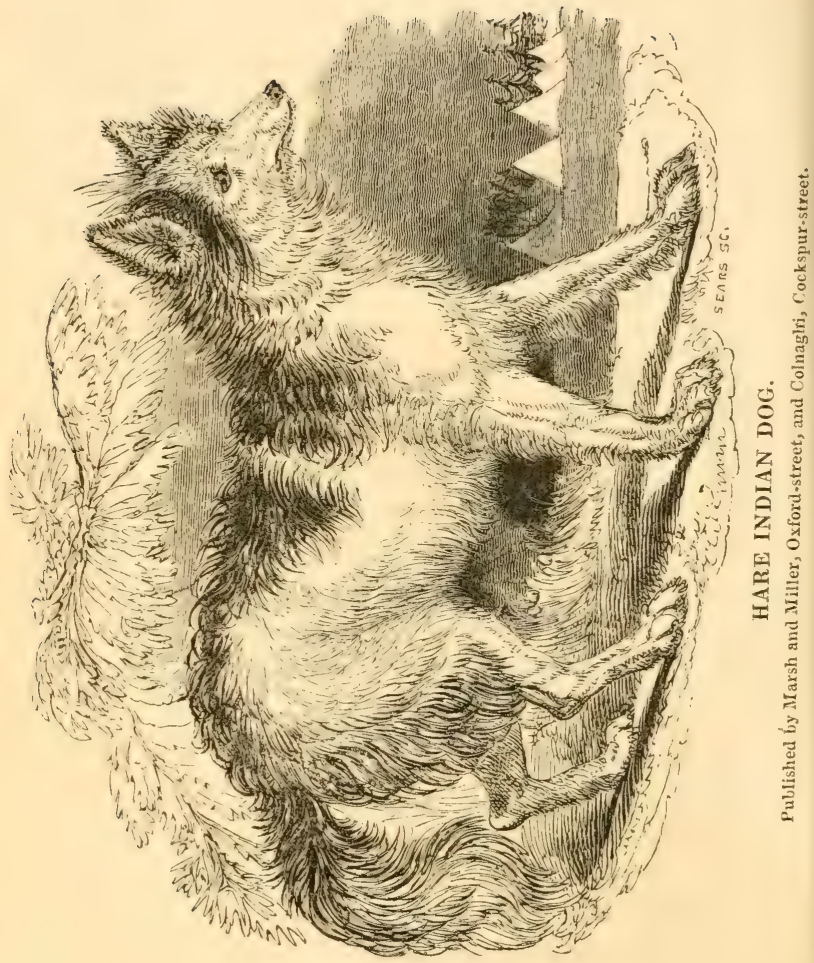




\section{ORIGINAL POETRY.}

THE LOST LAMB;

OR,

BY H. C. DEAKIN, ESQ.

Author of "Portraits of the Dead."

Mons rose upon the purple hills, In all his pomp display'd;

Flash'd forth like stars a hundred rills, In valley, plain, and glade. The foaming mist, day's chilly sinine,

Into the clouds upcurl'd, Forth broke in majesty divine The Grampians' giant world.

It was a glorious sight to view Those mountain forms unfold,'The Heavens above intensely blue, The plains beneath like gold. Day woke, a thousand songs arose, Morn's orisons on high, Earth's universal heart o'erflows To Him beyond the sky. 
The Shepherd roused him from his sleep,

And down the vale he hied,

Like guardian good, to count his sheep,

His Firstling by his side.

His Firstling! 'twas his only child-

A boy of three years old,

The father's weary hours beguiled

Whilst watching o'er his fold.

And many an hour the child and he

Joy'd o'er the vale together ;

It was a lovely thing to see

That child among the heather.

The vale is pass'd, the mountains rear

Their rugged cliffs in air,

He must ascend to view more near

His distant fleecy care.

"My child! the flowers are bright for thee,

The daisy 's pearl'd with dew;

Go, share them with the honey-bee,

Till I return for you.

Thy dog and mine with thee shall stay

Whilst I the flock am counting,"-

He said, and took his tedious way,

The hilly green-sward mounting.

O'er crag and cliff the father toil'd,

Unconscious pass'd the hours:

He for a time forgot the child

He 'd left among the flowers. 
The boiling clouds come down and veil

Valley, and wood, and plain ;

Then fears the father's heart assail,

He will descend again.

Morn melted into noon, and night

Dark on the shepherd shone,

Terror in vain impells his flight,

His child! - his child is gone!

His calls upon his darling's name,

His Dog in vain he calls;

He hears nought but the Eagle s scream,

Or roar of waterfalls.

He rushes home-he is not there-

With agony and woe;

He hunts him in the cold night air,

O'er hill and vale below.

Morn rose-the faithful Dog appears,

He whines for food so mild,

The father hied him through his tears,

And said, "Tray, where's my child?

Thrice rose the morn-the father's heart

With grief was almost dead;

But every morn the Dog appeared,

And whined and begged for bread.

Yet through the night and through the day,

The Dog was never seen;

"He is not wont to stay away,

Where can the Dug have been?' 


\section{6}

On the fourth morn this faithful friend,

As usual whined for meat;

They mark the way his footsteps tend,

And follow his retreat.

They watch him to a cave beside

The Grampian's craggy base;

Behold! the shepherd's wandering child Within the Dog's embrace!

He springs - he weeps away his cares,

He cries aloud with joy ;

He kneels, he sobs to Heaven his prayers,

For his redeemed boy.

Then, turning, hugs his favourite hound,

The trusty, true, and bold,

By whom was saved, through whom was found

The Firstling of his fold! 



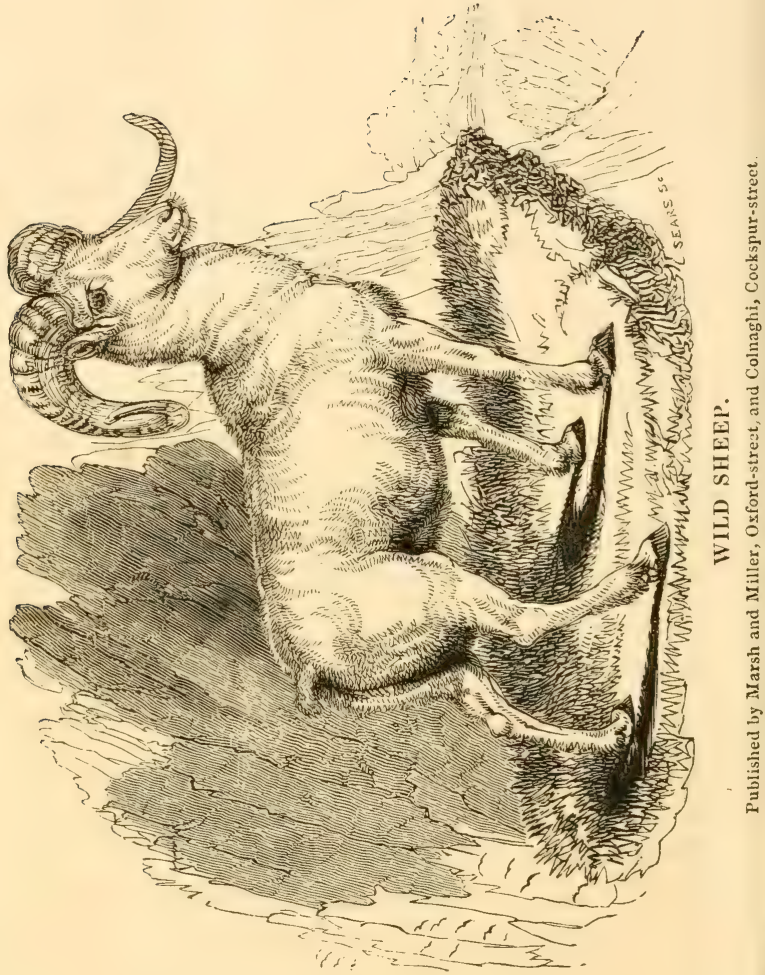


IVILD SHEEP.DALMATIAN DOǴ

WIJD SHEEP.-DOMLSTIC SHEEP.-LAMB AND DALMATIAN DOG.

IN the Society's Museum* we have specimens of the animal which, however disguised under various local and scientific names, by climate and situation, and by the coverings belonging to different seasons of the year, is the only Wild Sheep, or natural stock of all our domestic varieties of Sheep. It is a native of very cold countries, and of mountainous situations, and was formerly wild in Britain. In Summer, and in its natural state, its external coat differs little from that of the Deer, though it is provided with a wool beneath. In the dialect of some of the North American Indian natives, it is called Mi-attic, or the Ugly Deer, upon ac-

* No. 349, Mountain Sheep; and No. 349, Argali Sheep. 
count of its great curved horns, which are less admired than those of the Deer tribes.

But those horns, and the impenetrable forehead from which they grow, are the great resource and defence of the Wild Sheep. Upon his horns and forehead he throws himself fearlessly from lofty precipices; and he uses his horns also in ascending the rocks. The Wild Sheep, or Ram, uses his strength only in self-defence, or in combats with his fellows; but his capability of fighting, and the power which he has, is much greater than may be commonly imagined. The sportive buttings of Lambs fall under every one's observation; but it is asserted, that a grown and vigorous Ram, in contest with the Bull, can knock his opponent down, by striking the top of his head against the forehead of the latter.

An anecdote of the sudden attachment of a Lamb to a Dalmatian Dog, will both illustrate a part of the manners of Sheep, and afford a new example of the ease with which different species of animals often contract a kindness for each other.

"I took with me last Summer," says an 
English tourist, " one of those spotted Dogs called Danish, but the breed is Dalmatian. It was impossible for any thing to be more sportive, or more incffensive, than this Dog. Throughout the mountainous parts of Cumberland and scotland, his delight was to chase the Sheep, which he would follow with great alertness even to the summits of the most rugged steeps; and, when he had frightened them, and made them scamper to his satisfaction, (for he never attempied to injure them,) he constantly came back wagging his tail, and appearing rery happy at those caresses which we, perhaps absurdly, bestowed upon him.

"A About seven miles on this side Kinress, in the way from Stirling, he had been amusing himself playing these pranks, the sheep flying from him in all directions, when a black Lamb turned upon him, and looked him full in the face. He seemed astonished for an instant; but, before he could rally his resolution, the Lamb began to paw and play with him. It is impossible to describe the effect this had upon him. His tail was between his legs; he appeared in the utmost 
dread, and slunk away confused and distressed. Presently, his new acquaintance invited him, by all manner of gambols, to be friendly with him. What a moment for Pythagoras or Lavater! Gradually overcoming his fears, he accepted this brotherly challenge, and they raced away together, and rolled over one another like two kittens. Presently appeared another object of distress. The shepherd's boy came to reclaim his Lamb; but it paid no attention except to the Dog, and they were presently at a considerable distance. We slackened our pace for the convenience of the boy, but nothing would do; we could no more call off the Dog, than he could catch the Lamb. They continued sporting in this manner for more than a mile and a half. At length, having taken a circuit, they were in our rear; and after we had crossed a small bridge, the boy, with his pole, kept the Lamb at bay, and at length caught him; and having tied his plaid round him, it was impossible for him to escape. Out of fear of the boy, and in obedience to us, the Dog followed reluctantly; but the situation of the Lamb all 
this time cannot be pictured; he made every possible attempt to pass the boy, and even determined to jump into the river, rather than not follow the Dog! This continued till the prospect closed, and we had lost sight of our new ally, whose unexpected offer of amity to the Dalmatian seemed ever after to operate as a friendly admonition; for, from that day, he was cured of following Sheep !"

The Wild Sheep, of which two specimens of local varieties, with as many names, and of which many other local varieties and names might be mentioned, is a single species; and the Sheep is easily and broadly distinguished from every other animal upon the globe, if it were only by its horns. It is the cockneyism, however, of Europeans, in visiting foreign climates, or in contemplating their productions, to cry out sheep whereever they see wool; not understanding, that upon every animal whatever, which is either the natural native of very cold climates, or very hilly, or other situations, or can bear to ing : bo insperted thither, nature is always ready to produce a coat of wool beneath, and even sertopping the hair, as occasion 
may require; for, to almost every. quadruped, there belongs either a conspicuous or a latent under coat of wool, as to birds an under coat of down. But it is hence that the Spaniards, in South America, when they saw wool upon the Llama, cried out st Sheep;" and we have two recent instances in our own country, of this propensity to see something Sheepish wherever there is wool, such as are quite unworthy of modern science, or which, at least, discover how few of the great principles of Zoology are yet established. No. 32\%, in the Museum of the Society, is called in its Catalogue by no other than a barbarous assemblage of names, as if to describe the offscouring of all the mongrels in creation-such as Pliny supposed to be the source of so many various species of animals-the endless mixture of many. Alas! the nature of the Goat of North America, or North American Wild Goat, called, by Dr. Richardson, Rocky Mountain-Goat, * is described, in this Catalogue, as the Mountuin-Sheep-A atéciopi …

* Fauna Boreali-Americana, p. 268. 


\section{THE EAGLE AND THE OWL.}

TIE Owl and Eagle had been foes:

The first, as every body knows,

Is always call'd the bird of wisdom;

And for the royal Eagle, his doom

Is to control the realms of air,

And all things that inhabit there.

Th' aforesaid parties thinking, therefore,

That they were foes they scarce knew wherefore;

And deeming it no longer good

That royalty and wisdom should

With one another be at war,

(Although, alas! they often are,)

Now came to terms; their discord heal'd,

And articles were sign'd and seal'd.

The Owl confess'd the Eagle's worth;

The Eagle bound himself henceforth

To spare the children of the $\mathrm{Owl}$,

Content to feast on other fowl.

But, said the monarch of the air,

How shall I know your precious care?

My young, replied the bird of night,

Are most engaging to the sight,

With lovely shapes, and voices sweet,

In them all elegancies meet. 
The Eagle heard : and as he flew, Some little monsters met his view, Graceless, deform'd, whose horrid throats Pour'd forth a tide of screeching notes :

Not these the children of my friend,

Quoth he; on this I may depend. With that he took them for a meal, Dame Owl, in her maternal zeal, Having much flatter'd in her song, And painted all their portraits wrong.

From hence let doting parents know What ills from partial blindness flow, Nor deem those awkward brats refined, Which are but owlets in their kind. 


\section{THE CONDOR AND HARPY EAGLE OE SOU'TH AMERICA.}

YULTURES. - EAGLES. - IAMMER-GEYER. - GRYPHON VLLTLRE. - BEARDED EAGLE. - CONDOR. - IARPY EAGLE-CHILDRE AXD LAMBS CARRED AWAY BY EAGLES ONLY. - IAMB CARRIED BY AN EAGLE TO THE ISLE OF ARRAN. - CONDOR FAMILIES. - A SHEPHERD'S ADMIRATION OF THE TIGLRE AND CARRIAGE OF AN EAGLE. - THE EAGLE MADE THE EMBLEM OF THE DEITY. - THE ARABIAN ROE. THE CHINESE SIMORGH.

Vultures differ from Eagles both in figure and habits. The Lion preys upon what it kills, but the Boar, the carnivorous Bears, and the Hyæna, will feast upon carrion; and in what the Hyæna is among quadrupeds, such is the Vulture among birds. The appearance of the several species of the Vulture is usually plainly distinguishable from that of the species of the Eagle, because the former have naked, or nearly naked, heads 
and necks, with downy ruffs below, and horny combs upon their heads.

But all the subsisting distinctions between the Vulture and the Eagle do not prevent them passing under the same names, and being mistaken for each other, in all or most of the countries where both are seen. In Switzerland, the name of Isammer-geyer, or Lamb-stealer, is given both to the Bearded Eagle and to the Gryphon Vulture ; and, in South America, the name and description of the Condor, or what may be called South American Gryphon Vulture, are mixed with the History of the Harpy Eagle of the same country. In the Zoological Garden, we see both the Gryphon Vulture of Europe, and the Condor, or Gryphon Vulture, of South America; and a great degree of similitude between the two. The Society is also in possession of a living Harpy Eagle, from South America, which will shortly be exhibited.

It is to the Harpy Eagle, then, that we are to refer all or most of those stories of attacks, by a large and rapacious bird of South America, upon living animals, which we find 
related as belonging to the Condor; in the same manner that in Switzerland, what is related of the seizure of living animals by the Lammer-geyer, is to be understood of the Bearded Eagle; and what is related of the Lammer-geyer, as preying upon carrion, is to be understood, not of an Eagle, but of a Vulture; namely, the Gryphon Vulture of Europe. In South America, we are to reckon, either that "Condor" is a name given sometimes to its Gryphon Vulture, and sometimes to its Harpy Eagle; or, by the name of Condor, we are to understand specifically the South American Gryphon Vulture.

But the true histories, neither of the Condor nor Harpy Eagle, justify the ancient accounts, of the size, nor of the strength of the supposed Condor. The Condor has been said to measure eighteen feet across the wings; whereas, nine feet is the usual breadth, a dimension in which it is equalled by the Albatross; ten feet is large; and fourteen feet is spoken of as the extreme expansion ever discovered, and may have occasionally been found, either in the Condor or 
the Harpy Eagle. The length of a male specimen of the Condor, somewhat less than nine feet in expanse, was three feet three inches, from the tip of the beak to the extremity of the tail.

The Condor is difficult to kill. Humboldt relates, that during his stay at Riobamba, he was present at some experiments which were made on one by the Indians, who had taken it alive. They first strangled it with a lasso, or leathern thong, and then hanged it upon a tree, pulling it forcibly by the feet for several minutes; but scarcely was the lasso removed, when the bird arose, and walked about as if nothing had been done to it. It was then shot with three balls, discharged from a pistol at less than four paces, all of which entered its body, and wounded it in the neck, chest, and abdomen, yet, still, it kept its legs. It was only when a fourth ball struck its thigh that it fell to the ground.

With reference to the pretended accounts of the carrying away children by the Condor, M. Humboldt assures us that he never heard of such an instance; although the children 
THE CONDOR AND HARPY EAGLE. 159

of the Indians, who collect snow upon the mountains for sale, are incessantly left sleeping in the open air, in the midst of those birds: and with respect to the danger to grown persons, while he confesses that two of these birds would be powerful enemies for one man to cncounter, he states that he has himself frequently approached them within ten or twelve feet, as, three or four together, they sat perched upon the rocks, and that they showed no disposition to attack him. Moreover, the Indians of Quito assured him, that we have nothing to apprehend from the Condor.**

The confusion of ideas, between a Vulture and an Eagle, or between the Condor and the Harpy Eagle of South America, pervades even these observations; for, were any thing of the kind now mentioned to be

* The old naturalists are quite vehement upon the subject of the dangers awaited by travellers from the Condor; and, as a specimen of the exaggerations as to size, it may be mentioned, that Labat assures, from the alleged testimony of those who had seen the bird, that its body was as big as that of a Sheep! 
feared, it would be from the Harpy Eagle, and not from the Condor. Vultures, as we have already said, do not desire live prey; and it is Eagles alone which take away Lambs, and sometimes seize upon children. A Lammer-geyer Eagle seized upon a child, not very long since, in Switzerland; and there is now, or lately was, in the Isle of Arran, upon the coast of Galway, in Ireland, a solitary Sheep, which is a witness to the seizure of a Lamb by an Eagle. The breed of Sheep upon the Isle of Arran is very small and round; but an Eagle, having seized a Lamb upon the Coast of Galway, and carried it in his talons to the Isle of Arran, he was assailed by the islanders, while thus heavily laden; and, to make his escape, relinquished his prey. The long-legged Lamb was suffered to grow up among the small round Sheep of the island, and has lived a foreigner upon the soil to which he was transported by the Eagle.

While, upon the one hand, the histories of the Great Vulture, and Great Eagle, of South America, appear to be still mixed, that of the Great Vulture or Vultures alone 
appear to require discrimination; for, if accounts be true, South America has Condors very differently coloured from each other, either through sex, age, or variety. of some, it is said, the bcllies are scarlet; but the usual colours, as in the specimen in the Garden, and as in its neighbour the European Gryphon Tulture, are black, white, and gray. It is only the male which has large white patches on its wings. The fomale is wholly black and gray. It may be observed, that while in the male Condor in the Garden the quill feathers of the wings are white, and the upper parts of the wings black, in the ciryphon Vulture of Lurope, upon the opposite side of the eages, the quil! fathers are black, with the upper part of the wings of a brownish or fuscous gray.

The Condor is not usually found, either solitary or in flecks, but in groups of three or four; and these are probably the parents and offipring of a single family. The female is said to keep her young ones with her for a whole year. These birds live upon the greatest heights of the Andes, which they never leave but when presed by hunger; 
and to which they return as soon as they are able, apparently discomforted by breathing the heavier atmosphere of the lower country. But, for this reason, the climate of the Zoological Garden, and even of any part of England, must be little adapted to it. Its natural haunts are ten, and sometimes fifteen thousand feet above the level of the sea. It descends, however, from those great heights to escape the chilliness of the rainy season.

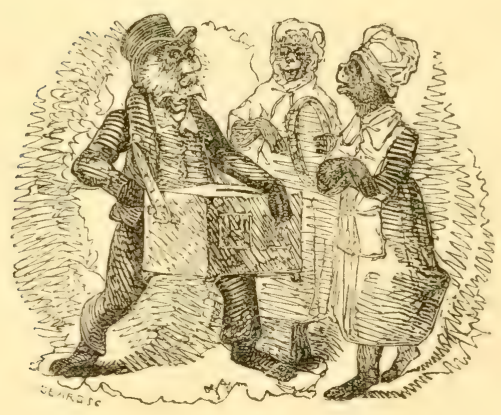





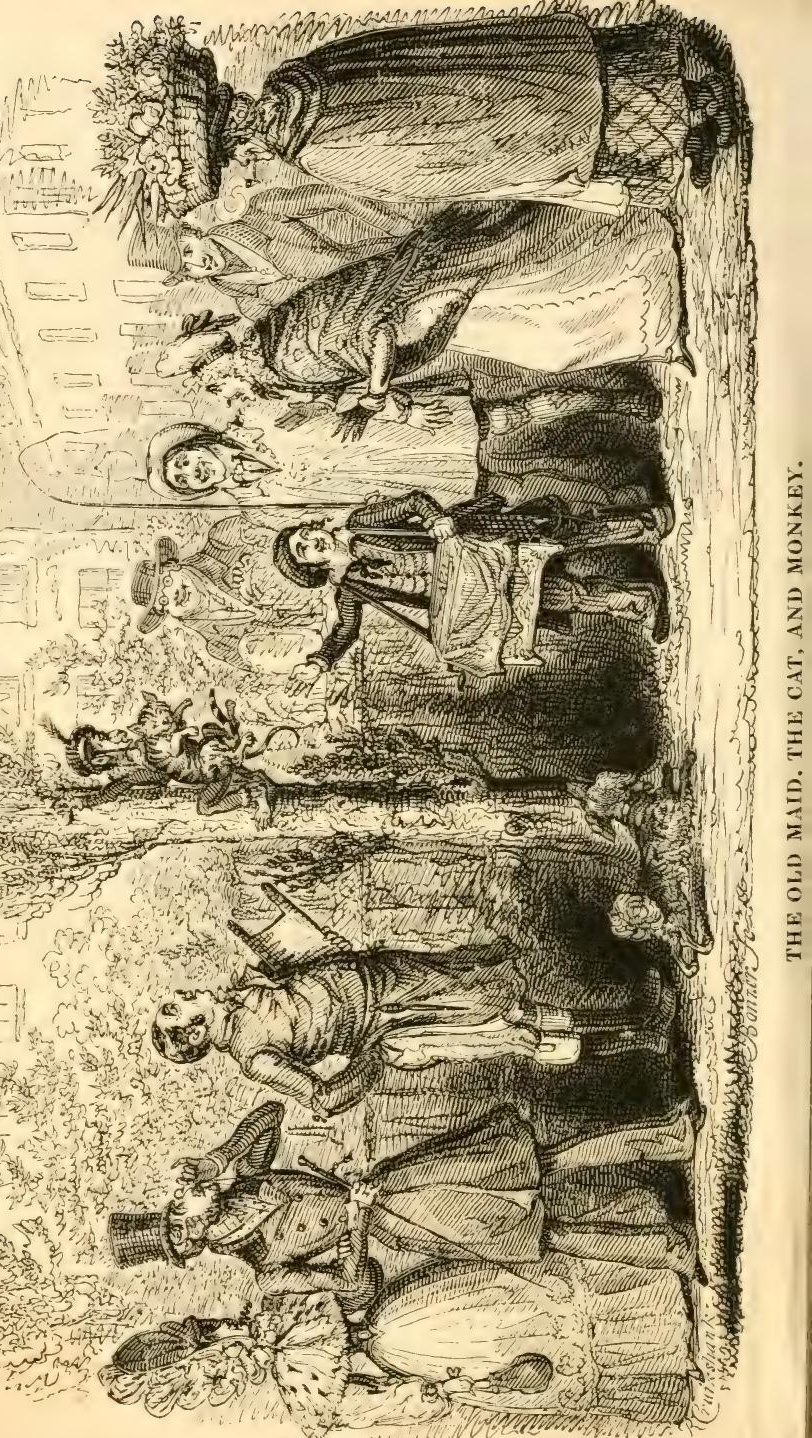




\section{3}

\section{THE OLD NIAD, THE CAT, AND THE MONKEY.}

Is the Kent-road there liv'd a Maid,

This sounds romantical:

But, reader, do not be afraid,

She was not young at all.

Now young maids and old maids, you know,

Are very different things ;

The first occasioning much woe, And wild imaginings.

But this good lady was too old

For flirting and all that, So all the tales of love she told, Were lavish'd on her cat.

In former days, indeed, she strove For love of man to wed, But having fail'd to man her love, She master'd it instead. P 4 
Yet women are a loving race,

And still keep loving on,

So pussy now supplied the place

Of once dear Celadon.

One liıckless day, poor pussy lay,

'The cares of morning done, And scarce could keep herself from sleep

While basking in the sun.

When lo !- now mark me, when a LO!

Like this appear's in verse,

You may be sure some dreadful woe

We 're going to rehearse.

A dog, an idle, naughty dog,

(All idle dogs are naughty,)

Spied pussy lying like a $\log$ -

'And now I have her,' thought he.

The cat her morning nap who took,

And little dreamt of evil,

Jump'd up and look'd as-you would look,

If you should see the devil.

And soon the least discerning eyes

The consequence might tell,

For Towser's back began to rise,

And pussy's tail to swell.

They growl'd and spit like any thing,

And most like man and wife ;

But soon the weaker took to wing,

And fled th' unequal strife. 
Perhaps that passage of the bard

Was then in pussy's eye,

Which well observes, "And since 'tis hard

To combat, learns to fly." **

Full speed they scramble down the place,

Puss first, and Towser after,

And boys-a mischief-loving race-

Join in with shouts and laughter.

Which would have beat, the dog or puss,

We never now can learn,

For just as things were going thus,

They took a curious turn.

Whether the gods considered it

A case for interfering;

Or whether puss, of her own wit,

A prudent course was steering.

Some blessed trees her steps invite,

Her shelter doom'd to be ;

And soon as they sprung up in sight,

Why, she sprung up a tree :

And clinging round it fast she strove

To 'scape her savage foe,

Preferring much the bark above

Unto the bark below.

* "Who quits a world, where strong temptations try, And since 'tis hard to combat, learns to fly."

Goldsmith's Deserted Village. 
This guest, thus mounting by the bark, The startled tree receives, And all the larks, at pussy's lark, Astonish'd leave the leaves.

The dog, who just arrived too late, Was left to growl and chafe; For dogs, like man, must yield to fate;

He saw that puss was safe.

She would not leave her seat, but sat

Secure from danger now ; And in the tree was grinning at The bou-wow, from the bough.

'The good old lady by this time Arrived all out of breath, Too late aware of Towser's crime, And fearing pussy's death !

And folks who came to crowd their fill,

Now gaping fill'd the crowd, And many stood with wonder still, And many spoke aloud.

A horrid woman came with a Tobacco-pipe in mouth, And smelling like-what shall I say?-

Why not like the "sweet south."

She stood with shoulders broad and bare, And arms stuck out a kimbo ;

Diverted to see pussy there

Stuck up in leafy limbo. 
IIer coming much increased the joke,

For folks kept joking at her,

But she, no matter for her smolie-

She came to smoke the mutter.

A Dandy also, said he should

Be glad, if they would please,

To make the matter understood,

And say what ail'd the trees.

Quoth he, "My senses surely fail,"

His eye-glass fix'd upon her,

"Or those are whiskers and a tail-

It is a cat-'pon honor!"”

A Butcher with his tray stood there,

It is a shocking trait,

In folks like these to stand and stare

When they should mind their way.

Some idle fit their fancy takes,

They leave their stalls and shops,

And when they ought to chop our steaks,

Alas! they stake our chops.

And now the group was join'd by one,

Or rather join'd by two,

A Boy, with Monkey perch'd upon

His shoulders, came in view

Such boys as these we often see

In London streets before us,

Playing Di tanti palpiti,

Or else the Huntsman's chorus. 
Attracting they with various charms

All hearers and beholders,

With hurdy-gurdies on their arms

And Monkeys on their shoulders.

When Pussy first ran off, the tune

He play'd was "Off She Goes,"

But chang'd it to "All's Well" as soon

As in the tree she rose.

And now the cry on ev'ry side

Was how to get her down,

And each of the spectators tried

Some method of his own.

The different folks had all their jokes

At Pussy's curious station;

Some shook the tree, some thought to coax,

Some tried intimidation.

The good old maid her hauds did wring,

"A shilling boon," quoth she,

"To him who will in safety bring

The cat from yonder tree."

The organ-boy he was no dunce,

The offer when he heard, he

Took up his monkey, and at once

Set down his hurdy-gurdy.

"And now," says he, " Jacko, my boy,"

And stroked him on the crown,

"This shining nut shall be your joy,

When you bring pussy down." 
The monkey jump'd, the monkey hopp'd, Leap'd up and scrambled round; In short, the monkey never stopp'd Till puss was on the ground.

What tears were shed o'er Pussy's head! How joy'd the maid to catch her !No wife who deems her husband dead And finds him safe, could match her!-

The crowd disperse-but ere they start, It is but fair to say,

That each according to his part Receiv'd his due that day.

The ancient maid her treasure grinsThe dog a swinging cutThe boy a shilling for his painsThe monkey has his nut.

Then let us all be thankful that There was no mischief done; $\Lambda$ maid, a monkey, and a cat, Yet all to end in fun!

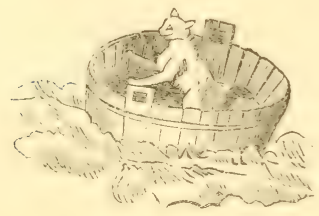




\section{EMOO-HOUSE.}

TMOO.*-CASSOWARY.- OSTRICII.-CARASOW-BIRDS.-

SUPERB MENURA. - ALBATROSS AND PELICAN.-PEIICAN ISLAND.-ANIMAL EARS FOR MUSIC.

After the Pelicans, our young friends paid a passing visit to their old acquaintances, the Emoos, or Emooes, or Ostriches of the Southern Hemisphere; and here Mr. Dartmouth was at pains to fix in the minds of his hearers distinct notions of the Emoo, Cassowary, and Ostrich respectively; for all these have some general resemblance to each other, and yet are exceedingly distinguishable; and, among other things, in height. The Ostrich is from seven to nine feet high, the Emoo six, and the Cassowary only five and a half. There is no Cassowary in any part of the Society's collection.

The Cassowary is of heavier proportions

* This has been variously written Emu, Emen, and Emew; but the sound intended is Emoo. 


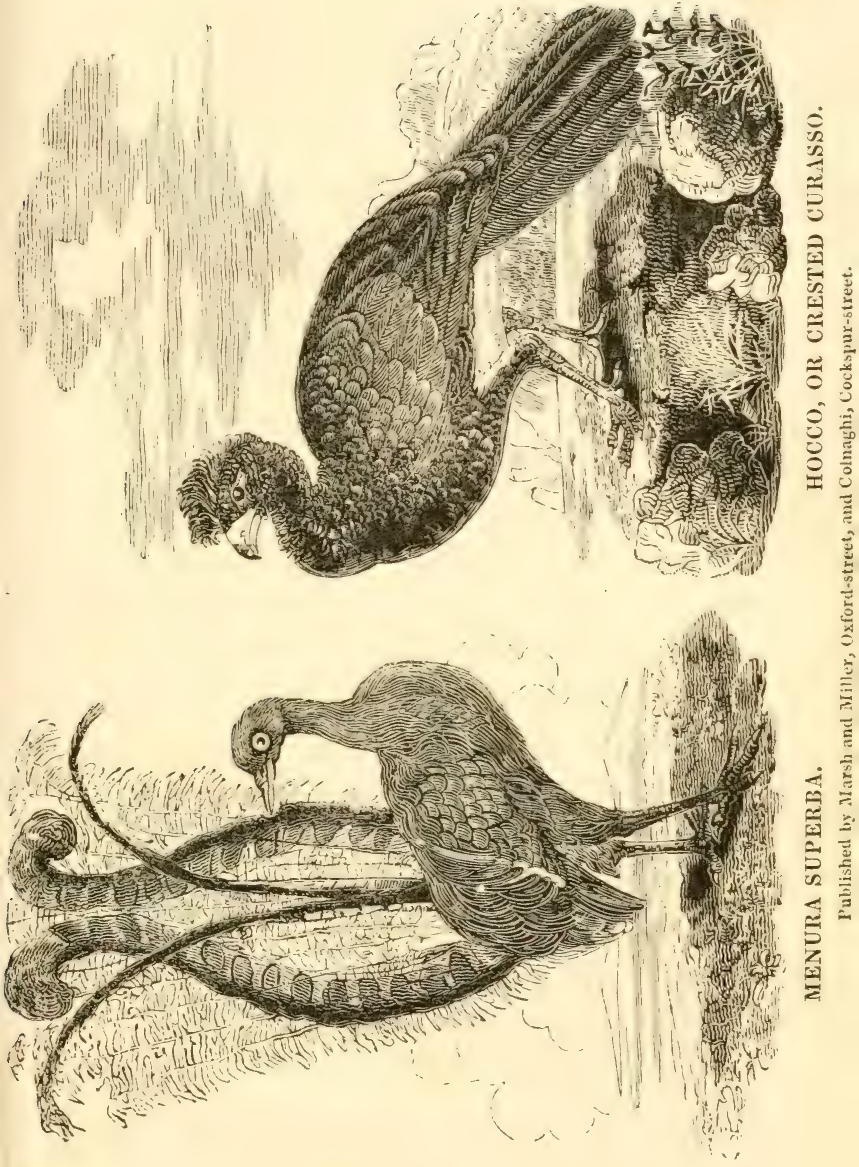



than either the Emoo or Ostrich, and not so tall. The legs of the Ostrich are three feet or more long, and those of the Cassowary only two and a half. These birds differ also in colour, and in the texture of their feathers. The Ostrich is a native of Africa; the Cassowary, of the Dutch and Portuguese East Indies; and the Emoo, apparently, both of Alistralia and South America. The East Indian bird, called Cassowary by the Dutch, and, from the Dutch, by the English, is called Emoo by the Portuguese; and, notwithstanding all the differences between the East Indian and South American birds, tixe Portuguese carried the same name of Emoo, or Cassowary, into South America, whence, again by the English, it has been extended to the bird found in New Holland, or Australia.

If the Emoo of South America entirely resembles that of New Holland, there are then but three birds of the Ostrich genus; namely, the Ostrich, the Emoo, and the Cassowary; and, of these, while both the Cassowary and Emoo differ much from the Ostrich, the Cassowary differs still more than the Emoo. The Emoo, among other things, 
ike the Cassowary, differs from the Ostrich in having three toes instead of two; but the Cassowary, besides other important variations, both from Ostrich and Emoo, is a bird of very different figure, because, besides being lower in its stature, is is of far heavier proportions. Each of the species, however, agrees with the others, in subsisting wholly upon vegetable diet; for the voracity imputed to them belongs only to the habit of swallowing all descriptions of heterogeneous things, but especially stones, as aids to digestion, in the same manner that stones and gravel are swallowed by all, or almost all, other kinds of birds. Each of the species, too, is strong, and upon some occasions, fierce in resistance and self-defence; but otherwise entirely gentle. The Ostrich,* from all antiquity, has been likened to the Camel; and upon the Emo, it has lately been attempted to fix a scientific appellation, which would recal the Dromedary ; $\uparrow$ and even the Cassowary, which appears to be

* Struthio Camelus.-Linn.

† Dromiceius Novæ Hollandiæ. Vieml..-Casuarius Novæ Hollandiæ.--Latham. 
less a bird of pasture than the other, and to have an internal conformation at least as different as its external, is only said to cat roots and fruit. The name of Ostrich, in French Autruche, is a singular derivative from the whimsical Latin mutilation, Ustruthio; itself a part of the whimsical Latino-Greek appellation of 'Camel us-struthio,' or Camel Sparrow; the name of Camel being applied to its figure, and that of sparrow, ironically, to its size!

The elder pair of the Emoos which we are looking at were hatched, as the list, or catalogue, informs us, at Windsor, and presented by His Majesty to the Zoological Society, and the younger, by Mr. Herries. All these birds, therefore, are perfectly domesticated. The catalogue secms to repeat an old mistake, that it is the male which always-that is, exclusively-sits upon the nest; but it would rather seem, that, both with the Emoo and Ostrich, the males only share with the females in that task. The female Emoo makes a drumming and very peculiar noise, which is one of the distinctions between the Emoo and the f strich. 


\section{The Ostrich is peculiar to the hotter} parts of Africa. A misapprehension appears to have long prevailed as to the practice of all the species, in respect to the hatching of its eggs, and rearing of its young. It has been said to leave them in the sand, and never to sit upon them; but in the first place, its habits, in these respects, have been found to vary with the degrees of climate; and in the second, several of the particulars connected with them appear to have become better understood. The Ostrich, if it sometimes leaves its eggs by day, carefully broods over them by night; and even the males, as well as the females, sit upon them by turns. Neither is it more true, that they forsake their young ones as soon as the latter leave the shell. On the contrary, the young, for several days after they are hatched, are unable to walk, and their parents are very assidur... in supplying them with grass and wate, and will encounter every danger in their defence. Some foundation, however, must have subsisted for the opposite accounts given, and this seems to consist in a part of the economy of the species, in which, 


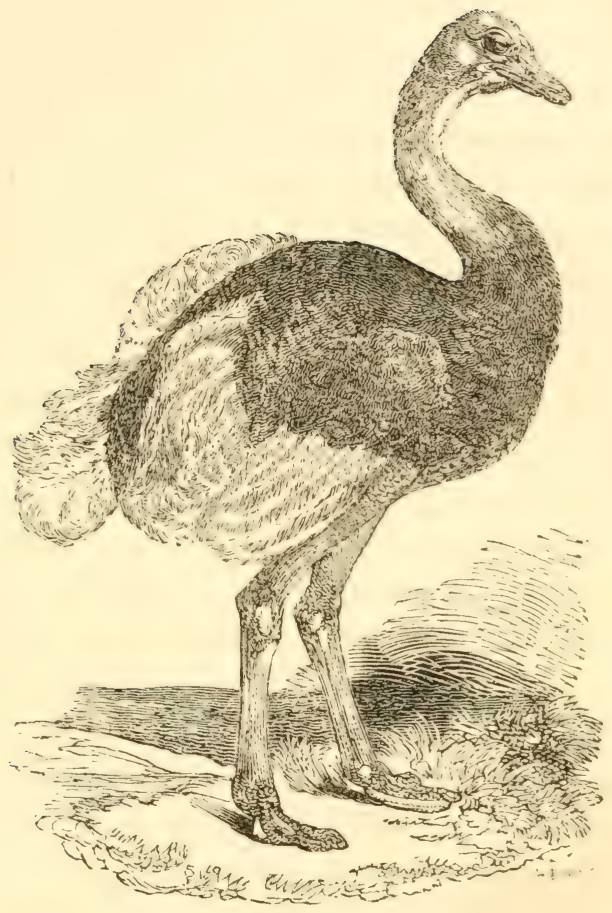

OSTRICH.

I'ublished by Marsh and Miller, Osford-street, and Colnaghi, Cockspur-street. 

if still correctly observed, there is a novelty the most remarkable.

M. Le Taillant, in his account of the Cape of Good Hope, informs us that he once started an Ostrich from its nest, in which he found eleven eggs, quite warm, which, "ppon breaking, were found to contain young ones. In the mean time, his attendants eagerly caught up four other eggs, which were at a little distance, and which they said were sound and good to eat. They informed him, that near an Ostrich's nest there are always placed a certain number of supernumerary eggs which are not sat upon, and which are designed for the first nourishment of the future young. "Experience," adds M. Le Taillant, "has convinced me of the truth of the account, for I never afterward met with an Ostrich's nest, without finding egos deposited in this manner." Some time after this, the traveller found a female Ostrich on a nest containing thirty-two eggs, and twelve eggs were arranged at a little distance, each in a separate cavity formed for it. He remained near the place some time, and saw three other females 
come and alternately seat themselves in the nest, each sitting a quarter of an hour, and then giving place to another, which, while waiting its turn, sat close to her that was to succeed. According to observers of the habits of the Emus, in South America, the manner in which the supernumerary eggs are designed to contribute to the nourishment of the young birds is different; namely, that having addled by the time the others are hatched, they are then broken by the parents, when the multitude of flies which settle upon them afford the young brood a supply of provisions. Both these stcries are in the highest degree improbable. From some cause not yet understood, supernumerary eggs are laid; but, to suppose any thing so contrary to the order of nature as that the young Ostrich's are to eat them, or so apparently trivial and inefficient as their sacrifice to the object of collecting supplies, is what we should receive with caution; especially when we have just before been told, that the young birds are fed by their parents with grass; and while the author last quoted assures us that the Fimoo lives 
wholly upon grass! There is an equal mistake, as we have already seen, in the supposition that the male Emoo, or the male of any of the Ostrich tribe, sits upon the egg's to the exclusion of the females.

In the Large Aviaries are specimens of the Crested Curassow, or Curassow, or Curassoa-bird, of our West India colonies, but of which the native name is Hocco. It is probable that within a very short period, the Curassow will be common in our poultryyards, and thus add to the number of exotic animals successively introduced into England, and placed within every one's reach. That species of public service is one of those which, as I have told you, the Zoological Society expressly aims at performing; but, in the present instance, its efforts appear to be anticipated. It is already domesticated in France, on the estate of M. Delafazette; and hen Curassows are now daily laying egg's in the yards of two gentlemen in the neighbourhood of Portsmouth, having been brought thither dircet from South Anerica, by a Mr. Mac Arthur, the son of one of them, who himseif is the gentleman that has 
178 CRESTED CURASSOW, OR HOCCO.

raised the large flocks of Merino Sheep in New South Wales, or Australasia. You observe the gold and green shadings of the black feathers with which these birds are wholly covered, and which are already rivalled by some of the fowls in our yards; but when the Curassow is domesticated, we must expect to see its colours vary, because this so often happens in similar cases. Besides the Crested Curassow, there are three other species of Aviaries, all of which we may some day see in our yards and on our tables. These are the Red Curassow, the Galcated Curassow, + and the Quan, $\S$ a native, like all the rest, of South America, somewhat resembling a 'Turkey, and long since domesticated at home. To this genus of birds Zoologists also refer that remarkable species from New Holland, which they call the Superb Menura.ll You have seen a specimen in the

* Crax Alector. Linn.-The Hocco of Guiana.

+ Cran Rubra. Linn.-The Hocco of Peru.

‡ Pauxi Galatea. Temm.-Crax Galatea. LATHAM.-Domesticated and used for the table in South America.

§ Meleagris Cristata. Linn.

\|l Menura Superba. Latham. 
CRESTED CURASSOW, OR HOCCO. 179

Museum at Bruton-street, and been equally surprized and pleased with the variety of structure and form of the feathers in its tail, the two lyre-like feathers particularly inclusive.

Reverting to what had passed concerning the Albatross and Pelican, and to the lines which had been quoted from the poem of Mr. James Montgomery, our party communicated to each other some doubts, whether the Pelicans of the poet's Island are really Pelicans, and not Albatrosses. There secms great reason to belicve that these birds, which nearly resemble each other in size, are much mistaken for each other; and the circumstance which fixed the attention of $\mathrm{Mr}$. Montgomery, and has become the foundation of his poem; that of the long generations of the birds, whatever were their names, which lived and died in peace upon Captain Flinders's Kangaroo Island, in a gulf upon the coast of New Holland, is possibly more characteristic of the fate of the tyrant Albatross, than of the rcal Pelican. At any rate, the report from Kangaroo Island is interesting, as affording one example at least, 
180 PELICANS, OR ALBATROSSES.

that amid the prevailing slaughter which is sometimes thought to bring the lives of the greater part of the animal world to its customary close, there are thousands upon thousands, of this kind or that, which live out their term, and perish only from decay. Captain Flinders relates, that upon two of the small islands, in one of those bays which he calls lagoons, he "found many young Pelicans unable to fly. Flocks of the old birds were sitting upon the beaches of the lagoon, and it appeared that the islands were their breeding places; not only so, but from the number of skeletons and bones there scattered, it should seem, that for ages these had been selected for the closing scene of their existence. Certainly none more likely to be free from disturbance of every kind could have been chosen, than these islets of a hidden lagoon of an uninhabited island, situate upon an unknown coast, near the Antipodes of Europe; nor can any thing be more consonant than their feelings, if Pelicans have any, than quietly to resign their breath, surrounded by their progeny, and in the same spont wh. 
Now, the islands of Captain Nlinders are in the same division of the world with the Falkland Islands, which are crowded with Albatrosses, which some call Pelicans; and I cannot help suspecting that his Pelieans, and all the Pelicans of New Holland, are Nlbatrosses. Be this as it may, "The Pelican Island" is a very pretty poem, especially the first six cantos. The author's progressive rreation, from water to fish and corallines, from corallines to islands, continents, and regetation, and from regetation to birds and beasts, is beautifully told. It is in this manner that he first introduces his Pelicans :-

"The sun had sunk where sky and ocean meet, And each might seem the other ; sky below, With richest garniture of clouds inlaid;

Ocean above with isles and continents, Illumined from a source no longer seen :

Far in the east, through heavens intenser blue. Two brilliant sparks, like sudden stars, appear'd ; Not stars indeed, but birds of mighty wing, Retorted neck, and javelin-pointed bill, That mate the air sigh as they cut it through. They gain'd upon the eye, and as they came, Enlarged, grew brighter, and displey'? their forms 
Amidst the golden evening; pearly-white, But ruby-tinctured. On the loftiest cliff They settled, hovering ere they touch'd the ground, And uttering, in a language of their own, Yet such as every ear might understand, And every bosom answer, notes of joy, And gratulation for that resting-place. Stately and beautiful they stood, and clapt Their van-broad pinions, streak'd their ruffled plumes, And ever and anon broke off to gaze, With yearning pleasure, told in gentle murmurs, On that strange land their destined home and country.

Night round them threw her brown transparent gloom,

Through which their lonely images yet shone, Like things unearthly, while they bow'd their hearls On their full bosoms, and reposed till morn. I knew the Pelicans, and cried-" All hail! Ye future dwellers in the wilderness !"

At early dawn I mark'd them in the sky, Catching the morning colours on their plumes; Not in voluptuous pastime revelling there, Among the rosy clouds, while orient heaven Flamed like the opening gates of Paradise, Whence issued forth the Angel of the sun, And gladden'd Nature with returning day : -Eager for food their searching eyes they fix'd On ocean's unroll'd volume, from an height, That brought immensity within their scope; 
Tet with such power of vision look'd they down, As though they wateh'd the shell-fish slowly gliding O'er sunken recks, or climbing trees of coral. On indefatigable wing upheld, Breath, pulse, existence, seem'd suspended in them; They were as pictures painted on the sky; Till suddenly, aslant, away they shot, Like meteors changed from stars to gleans of lightning,

And struck upon the deep ; where, in wild play, Their quary flounder'd, unsuspecting harm, With terrible voracity, they plunged Their heads among the affrighted shoals, and beat A tempest on the surges with their wings, Till flashing clouds of foam and spray conceal'd them. Nimbly they seized and secreted their prey, Alive and wriggling in the elastic net, Which Nature hung beneath their grasping beaks; Till, swoln with captures, the unwieldy burthen Clogg'd their slow flight, as heavily to land These mighty hunters of the deep return'd. There on the cragged cliffs they perch'd at ease, Gorging their hapless victims one by one; Then full and weary, side by sile, they slept, Till erening roused them to the chase again."<smiles>[13CH3]C[13CH2][13CH3]</smiles>

"Love found that lonely couple on their iste, And soon surrounded them with blithe companions. The noble birds, with skill spontancous, framed A nest of reeds among the giant-grass, That waved in lights and shadows o'er the soil." 
But, if the poet's Swans are not Geese, assuredly his Pelicans are Albatrosses! The succeeding lines are conclusive :-

“ Nature's prime favourites were the Pelicans; IIigh-fed, long-lived, and sociable and free, They ranged in wedded pairs, or martial bands, For play or slaughter. Oft have I beheld

A little army take the wat'ry field,

With outstretch'd pinions form a spacious ring, Then pressing to the centre, through the wares, Enclose thick shoals within their narrowing toils, Till multitudes entangled fell a prey :

Or, when the fiying-fish in sudden clouds Burst from the sea, and flutter'd through the air, These giant fowlers snapt them, like musquitos By swallows hunted through the summer sky."

After what we have heard, the mention of the Flying-fish must be fatal; and the "Giant-fowlers," with their " outstretched pinions," are no other than Albatrosses. The " javelin-pointed bill" agrees but little with the true description of the hunter of the Flying-fish ; for the bill of the Albatross, as well as the whole figure of the bird, reminds us more or less of the Eagle; and this, mo doubt, is the Pelccantis Aquillus of Lin- 
OF THE SOUTHERN HEMISPHERE. 185

nxus, or Frigate-bird* Pelican of the Zoological Museum, and of so many other attthorities. The truth is, that the Southern Hemisphere has no Pelican; but if Captain Flinders and others have misied Mr. Montgomery into the belief, that his Pirates and Men-of- IV ar Birds are not only Pelicans, but Pelicans, too, of the Wilderness, -

"Ye future drellers in the Wilderness-"

he does but err with many others, as well poets as travellers, and even naturalists. The author of that chaming poen, the Pleasures of Hope, in Lines upon the Emigrants to the Swan-river, has very lately anticipated for New Holland,-

"What spacious cities, with their spires, shall gleam, Where now the Panther laps a lonely stream ;-"

and yet, most certainly, there is no more a Panther to lap the streams of Australia, than there is a Pelican, to breed and die upon its islands !

In an after-part of the day, Mrs. Aston, recurring to what had been said about the * Tachypetes aquila.-VIEILL. 
passion of the Pelican for Music, and to the interesting remarks which might even be made upon that subject, requested George to read, from a volume in the library, the remarks of a Frenchman upon the taste of music discoverable in several species of animals. They are far less favourable to the claims of the animal world to musical sensibility than is generally thought, and perhaps than is really true; but it may be worth while to hear what the present experimentalist advances :-

"Doubting," says he, "the accuracy of those who say it is natural for us to love music, and especially that music which consists in the sounds of instruments, and that beasts themselves arc touched with it, I endeavoured, one day, when I was in the country, to determine the point at issue; wherefore, while a man was playing on the Frenchhorn, I made my observations on a Cat, a Dog, a Horse, an Ass, Cows, small Birds and a Cock and Hen, which were in a yard, under a window, upon the sill of which I was leaning. of these, I could not perecive that the ('at was at all affected; and I was even 
of opinion, from her manner, that she would have given all the instruments in the world for a mouse. She slept in the sun during the whole time. The Horse stopped short, from time to time, before the window, lifting his head up now and then, as he was feeding in the grass. The Dog, for above an hour, continued seated upon his haunches, looking steadfastly at the player. The Ass, peaceably eating his thistles, did not discover the least indication of his being moved. The Hind lifted up her large white ears, and seemed very attentive. The Cows slept a little; and, after gazing as though they had been acquainted with us, went forward. Some Birds, which were in an aviary, and others that were on the trees and bushes, almost tore their throats with singing; but the Cock, who minded only his Hens, and the Hens, who were solely employed in scratching up a neighbouring dunghill, did not betray, in any manner, that they took the least pieasure in hearing the French-horn." 


\section{8}

\section{ORIGINAI, POEIRY.}

\section{- \\ ZLLEIKA AND IIER GAZELLE.}

BY H. W. IIONTAGU.

[Derived, in part, from some lines said to have been composed by a daughter of the present Shah of Persia, in the Palace Girlens, near Teheran, in 1828.]

I

LIFE is indeed a wild of woe, 'Though poets fain would find Some trace of Adan's* thrill below,

To soothe the wearied mind;

Which seeks in vain,

Through tears of pain,

A bright light from above,

Until is wean'd our mortal love

From dreams of earth, -and then we see

The dawning of felicity.

I I.

Bring me the flowers which Haif bound

Fair on his dazzling brow,-

And I will twine their sweets around

Thy forehead, with a vow,

"Or Aden: Jomn't dden-the Garlen of Paradise;-also, Junnat al Ferdaws. 
ZULEIKA AND HER GAZELLE, 189

My own Gazelle,-

Ah ! loved too well!

Yet in whose eye Zuleika see,

So earthless, calm, the spirit's case,

And in thy placid fond caress

C'an almost baffie earth's distre's !

III.

Thou hast no thought of passion's ill,-

Ambition doth not waste

Thy fair white form, on which the seal

Of innocence is placed:-

Thy playful air

No dark despair,

Nor even hope may dim;

A thing of light, an angel-tream,

Thou seem'st,-for all in thee unfolits

What heaven, one transient hour, withhouis ? 


\section{BEARS, AND BEAR-HUNTS, AND BEAR- DANCES, AND BEAR-FEASTS.}

BEAR-HUNTS AND BEAR-DANCES IN LAPLAND.DEAHIIUNTS AND BEAR-FEASTS IN NORTII AMERICA.BLACE BEAR.- BROWN BEAR.- GRISLY BEAR.WIITE BEAR.-SLOTH BEAR.-BROWN BEARS FROM CALIFORNIA.-SUN BEARS.

The Society's collection, living and dead, is rich in Bears; and the whole list of species of the Bear kind have qualities, and are connected with histories, which command much attention. The other day we spoke of Bears as they are treated by mankind in the semi-barbarous conditions of society; and it may now be curious to look at them as connected with man in their pastoral and even hunter state.

"The strength and agility of the Bear," says Dr. Richardson, " together with its tenacity of life, render an attack upon it ha- 
zardous, and its chase has been considered by the rude inhabitants of the Northern regions as a matter of the highest importance. Many of the native tribes of America will not join the chase until they have propitiated the whole race of Bears by certain speeches and ceremonies; and, when the animal is slain, they treat it with the utmost respect, speak of it as a relation, offer it a pipe to smoke, and scldom fail to make a speech in exculpation of the act of violence they have committed in slaying it, although the hunter, at the same time, glories in his prowess. This reneration for the Bear scems to have arisen from the ability and pertinacity with. which it defends itself; and it is interesting to observe in how similar a manner the same feeling manifests itself in tribes speaking diverse languages, and widely separated from each other by geographical position. Thus Regnard informs us, that the chase of the Bear is the most solemn action of the Laplander, and the successful hunter may be known by, and exults in, the number of tufts of Bear's hair he wears in his bonnet. When the retreat of a Bear is discovered, 
the ablest sorcerer of the tribe beats the runic drum, * to discover the event of the chase, and the side on which the animal ought to be assailed. During the attack, the hunters join in a prescribed chorus, and beg earvestly of the Bear that he will do them no mischief. When they have killed him, they put the body into a sledge to carry it home, and the Rein-deer which has been employed to draw it, is exempted from labour during the rest of the year. A new hut is constructed expressly for the purpose of cooking the flesh; and the huntsmen, joined by their wives, begin again their songs of joy, and of thanks to the animal for permitting them to return in safety. Leams also acquaints us, that the Laplanders never presume to call the Bear by its proper name of 'Guourhja,' but term it 'the Old Man in the fur clcak,' because they esteem it to have the strength of len men, and the sense

* "The same lind of drum," says Dr. Richardson, "shaped like a double-headed tambourine, and painted with arbitrary characters, or rule representations of wild beasts and of the heavenly bodies, is common throughout all the various North American tribes." 
of twelve.* It is also said, by the Kamtschatkans, that the Bear is the great master of medicine, surgery, and the polite arts. They observe the herbs he has recourse to when ill or wounded, and acknowledge him as their duncing-master, mimicking his attitudes and graces with great aptness. Bear-dances, in which the gestures of the animals are copied,

* It is known that among the North American Indians, as, at different periods, among all other nations, the names of animals, and parts of animals, supply many of the names of men. But, with these nations, it is esteemed one of the grossest breaches of decorum to call an animal, or part of an animal, by its direct name, in the presence of any man or woman by whom that name is borne. Politeness, in such a case, requires periphrasis, or circumlocution; and some one or other of the numerous, and sometimes long descriptive appellations of the animal, or of its head or limbs, must be employed. As parallel cases, an American savage would be horrified at the European rudeness of speaking, by such names, of a baker, a smith, or urolf, in the presence of a Mr. Baker, a Mrs. Smith, or a Miss or Master Wolfe. A periphrasis is requisite; and the baker should be described as a "man who makes bread," or in some other manner still less obviously allied to the name of Mr. Baker, \&c. \&c. 
are also common with the North American Indians.

" The following extract," continues Dr. Richardson, "from the narrative of $\mathrm{Mr}$. Alexander Henry, one of the first English. men who penetrated into the fur countries, after the reduction of Canada under the British arms, will serve to contrast the manners of the Indians with those of the Laplanders; and it contains, besides, some remarks on the habits of the Bear, peculiarly raluable, on coming from an eye-witness worthy of all credit:- In the month of January, (whilst on the banks of Lake Michigan,) I happened to observe that the trunk of a very large pine-tree was much torn by the claws of a Bear, made both by going up and coming down. On further examination, I saw that there was a large opening in the upper part, near which the smaller branches were broken. From these remarks, and from the additional circumstance that there were no tracks on the snow, there was reason to believe that a Bear lay concealed in the tree. On returning to the lodge, * I communicated my dis* The late Mr. IIenry, an old and respectable in- 
covery; and it was agreed that all the family should go together, in the morning, to assist in cutting down the tree, the girth of which was not less than three fathoms. The women, at first, opposed the undertaking, because our axes, being only of a pound and a half weight, were not well adapted to so heavy a labour; but the hope of finding a large Bear, and obtaining from its fat a great quantity of oil, an article at the time much wanted, at length prevailed. Accordingly, in the morning, we surrounded the tree, both men and women, as many at a time as could conveniently work at it and there we toiled, like Beavers, till the sun went down. The day's work carried us about half-way through the trunk; and the next morning

habitant of Montreal, in Lower Canada, whose "Travels and Adrentures in the Indian Territories" are here quoted by Dr. Richardson, and who was known to the writer of this note, was a very young man at the date of the transactions to which the work refers; and, as a consequence of some disasters of climate, which befel his first beginnings in travelling the fur-countries, he was, at the date of the discoveries of the Bear, passing the winter in the lorlye or wigwam of an Indian hunter and his fimily. 
we renewed the attack, continuing it till about two o'clock in the afternoon, when the tree fell to the ground. For a few minutes, every thing remained quiet, and I feared that all our expectations were disappointed; but, as I advanced to the opening, there came out, to the great satisfaction of all our party, a Bear of extraordinary size, which, before she had proceeded many yards, I shot.

" The Bear being dead, all my assistants approached; and all, but particularly my Old Mother, (as I was wont to call her,) took her head in their hands, stroking and kissing it several times, begging a thousand pardons for taking away her life, calling her their relative and grandmother, and requesting not to lay the fault upon them, since, in truth, it was an Englishman that had put her to death! This ceremony was not of long duration; and if it was I that really killed their grandmother, they were not themselves behind-hand in what remained to be performed! The skin being taken off, we found the fat, in several places, six inches deep. This, being divided into two parts, loaded two persons; and the flesh parts were as 
much as four could carry. In all, the carcase must have exceeded five hundred weight. As soon as we reached the lodge, the Bear's head was adorned with all the trinkets in the possession of the family, (such as silver armbands and wrist-bands, and belts of wampum,) and then laid upon a scaffold, set up for its reception, within the lodge. Near the nose was placed a large quantity of tobacco.

"The next morning no sooner appeared, than preparations were made for a feast to the manes. The lodge was cleaned and swept, and the head of the Bear lifted up, and a new stroud blanket, which had never been used before, spread under it. The pipes were now lighted; and Wawatam blew tobacco-smoke into the nostrils of the Bear, telling me also to do the same, and thus to appease the anger of the Bear, upon account of my having killed her. I endearoured to persuade my benefactor and friendly adviser, that she had no longer any life, and I assured lim that I was under no apprehensions from her displeasure; but the first proposition obtained little eredit, and the second gave 
but little satisfaction. At length, the feast being ready, Wawatam made a speech, resembling, in many things, his address to the manes of his relations and departed companions; and, then, we all ate heartily of the Bear's flesh !

"It is only the female Bear that makes her winter-lodging in the upper parts of trees, a practice by which her young are secured from the attacks of Wolves and other animals. She brings forth in the winterseason, and remains in her lodge till the cubs have gained some strength. The male always lodges in the ground, under the roots of trees. He takes to that habitation when the snow falls, and remains there till it has disappeared. The Indians remark, that the Bear comes out in the spring, with the same fat which he carries in with him in the autumn; but, after the exercise of only a few days, becomes lean. Excepting for a short part of the summer, the male of this species lives constantly alone."

The foregoing extract is from the excellent work of Dr. Richardson, on the Zoology of North America, recently published and 
BROTVN BEAR, GRISLY BEAR, ETC. 199

illustrated at the expense of His Majesty's Government, by the spirited designs and etchings of Mr. Thomas Landseer ; * and the rolume here quoted by the author, was written by Mr. Kendall, from the notes and conversation of $\mathrm{Mr}$. Henry, during a tour of the former in Upper and Lower Canada, and the United States of North America. But Dr. Richardson may appear to have fallen into error, in referring the above anecdote of Mr. Henry's Bear to the history of the Black Bear of America. Among the free-traders, three species of Bear are commonly spoken of; namely, the Brown Bear, the Grisly Bear, the Black Bear, which latter is small, and sometimes approaches the gardens and houses of the settlers, where, however, it threatens the safety of nothing, unless that of the bacon or the meal-tub; while the Brown Bear is more to be feared, and the Grisly Bear most of all. The "Little Black Bear," and, by the way, this is a common name for a man among the Indians, belongs to the more northern coun-

* Fauna Borealia Americana, \&e. By John Richardson, M.D. 4to. London. 1829. 
200 BROWN BEAR, GRISLY BEAR, ETC.

tries, whence it sometimes migrates to the southward in the winter; the Brown Bear, which is larger, lives usually more southward, and the Grisly Bear, which is the largest, southernmost of all. With deference to the researches of Dr. Richardson and his colleagues, these three Bears are precisely (1) the Ursus Americanus, or American Black Bear; (2) the Ursus (Arctos?) Americanos, or Brown Bear, or Barren-ground Bear; and (3) the Ursus Ferox, or Grisly Bear, of their beautiful and scientific work. That work, however, while acknowledging, that the facts are obscure, treats the Brown Bear of America as no more than a variety of the Black Bear of the same country. Both of these Bears are here represented as about five feet in length. Mir. Henry's bear was certainly a Brown Bear, whether a variety of the Black Bear or otherwise. The forehead of the Black Bear of America is said to be less flat than that of the Black Bcar of Nurope, though more so than the forehead of the Brown Bear of America. According to the Phrenologists, that conformation of the cranium 
should imply, in the American Brown Bear, the mildest disposition of the three; and it is asserted, that even the Black Bear of America is of a milder disposition, and lives more upon regetable food, than the Black Bear of Europe; and I am happy to add, that it is identically a specimen of this American 'Little Black Bear,' which is your favourite in this Garden, and who is generally thought to lose his share of presents of cakes and fruits, through the smallness of his size, but still more through the gentleness of his manners; upon which account, I could wish him separated from his stronger and less diffident companions.* The European Brown Bear, which is one of its companions, was brought from Russia by the Marquis of Hertford, by whom it was presented to the Society; and the 'Large American Bear,' $\dagger$ (so called in the Garden List,) a feeder, like the rest, upon regetables, is what I take to

* Some accounts of the Zoological Garden erroneously describe this Bear as the "Rugged Russian Bear," next referred to above.

† Ursus (Aretos?) Americanus (Fauna BorealiAmericana ;) or Common American Brown Bear. 
be the Bear of the anecdote quoted by Dr. Richardson, and which is not to be confounded with the Grisly Bear,* which preys upon the Bison, Bonassus, or Wild Ox, in the prairies, or plains of North America, which has been known to seize and carry away a man; and of which the weight often exceeds eight hundred pounds, and which sometimes measures more than nine feet from the nose to the tail. In reality, the Grisly Bear is inferior in size only to the White Bear: and, with greatly superior strength, is almost as carnivorous as the Wolf."

It was now the month of September, and the White Bear, in its den in the Garden, seemed to employ its waking hours in a mode of action which the party were half disposed to think might have reference to the instinct of the species, to hybernate, or burrow into the snow for winter, on the early departure of the sun in the northern parts of our hemisphere. Unlike all the other animals confined, its motion was not from right to left, and left to right, trying, again and again, to discover a passage between the bars in the * Ursus Ferox. 
fronts of their prisons; but the IVhite Bear moved backward and forward, in a line parallel to the bars, waving its long and weasel-like head and neck, scratching the floor with its paws, and moving backward till stopped by the partition behind it; then advancing quietly to the other end; and then retreating back again, scratching, and moving its head horizontally, as before. If he had been in the act of making his way into a bank of snow, working partly with his muzzle, and partly with his feet, and throwing out the snow behind him in the way that all animals burrow, this might seem to have been the natural action required; and nothing is more frequently to be observed in nature, than that animals perform certain actions instinctively at each retum of certain seasons, though the circumstances in which they happen to be placed render them unavailing, in the same manner that plants put forth leaves and blossoms at the times adapted to their original climates, rather than to those into which they are transplanted.

The conversation upon the TWhite, or Polar Bear, and upon so many other Bears 
of the Northern regions, and of North America more particularly, led the company, by a natural progress, to recollections of the sufferings of Captain (now Sir John) Franklin, Dr. Richardson, and others, on the overland expedition intended for meeting with Captain Parry at the mouth of the Coppermine River, and thence to the accounts given by those gentlemen of the Aurora Borealis, as seen in those high latitudes, and where its corruscations are attended by sounds like that produced by a quick furling and unfurling of a silken flag. Mr. Dartmouth cited some curious proofs, that confused accounts of these Polar phenomena had reached those southern nations whom we usually call the ancients; and referred, for new and important views of their natural history, to an account of the Aurora witnessed in London two years ago; ; and Miss

* See an account of the Aurora Borealis seen in London, on the evening of the 25th of September, 1827, and of various appearances of the Aurora in the Northern and Southern Hemispheres, by E. A. KEXIALL, EsQ. F.S.A. Quarterly Journal of Science and Art, January, 1828. 
Aston produced a manuscript poem from the pen of a lady, occasioned by another appearance of the same metcor, a twelvemonth after.

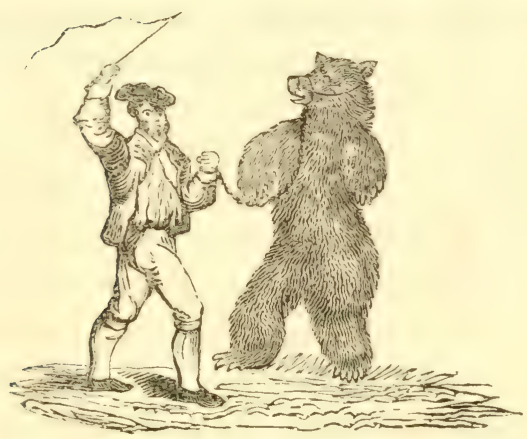




\section{6}

\section{ORIGINAI, POETRY.}

\section{THE LUMINOUS ARCH,}

That appeared in the Hearens on the night of the s9th of September, 1828.

BY MISS SUSANNAH STRICKLAND.

VISION of beauty,

There floats not a cloud

O'er the blue vault of heaven, Thy glory to shroud!

The star-gemm'd horizon Thou spannest sublime,

Like the path to a better And lovelier clime.

Thy light, unreflected By planet or star,

Still widens, and brightens,

Round Night's spangled car ;

In radiance resembling

The Moon's placid beam,

When she smiles through the soft mist

That floats on the stream! 
Thou sittest enthroned

Like the Spirit of Night,

And the stars through thy zone

Shed a tremulous light:

The Moon is still sleeping

Beneath the wide sea;

While Wonder is keeping

Her vigils with thee!

The Bow of the Covenant

Smiles on the storm,

When its dark wings are shading

The brow of the morn;

But thou art uncradled

By vapour or cloud;

Thy glory unshaded

By Night's sable shroud.

Then whence is thy splendour,

Fair luminous bow?

From life's golden chalice

Thy radiance must flow.

Thou look'st, from the throne

Of thy brightness above,

On this desolate earth,

Like the Spirit of Love! 
GREATER KANGAROO, JERBOA, AND LABRADOR JUMPING MOUSE.

COMPARATIVE FIGURES, DIMENSIONS, AND HABITS OF TIE KANGAROO, JERBOA, AND LABRADOR JUMPING Mouse.

KANGARoos are found only in New Holland, or New South Wales, and in $\mathrm{V}$ an Diemen's Land, where there are three species, or varieties, of which that called the Greater, is seen in the Garden and Museum, and is at present bred with great facility in several parts of England. The Kangaroos are allies to the Opossum, upon account of the bag in which the female carries its young; and to the Jerboa, (though vastly superior in size, upon account of its form and modes of moving, feeding, and living.

The Greater Kangaroo, which sometimes measures nine feet, from the tip of the nose to the end of the tail, and weighs a hundred 


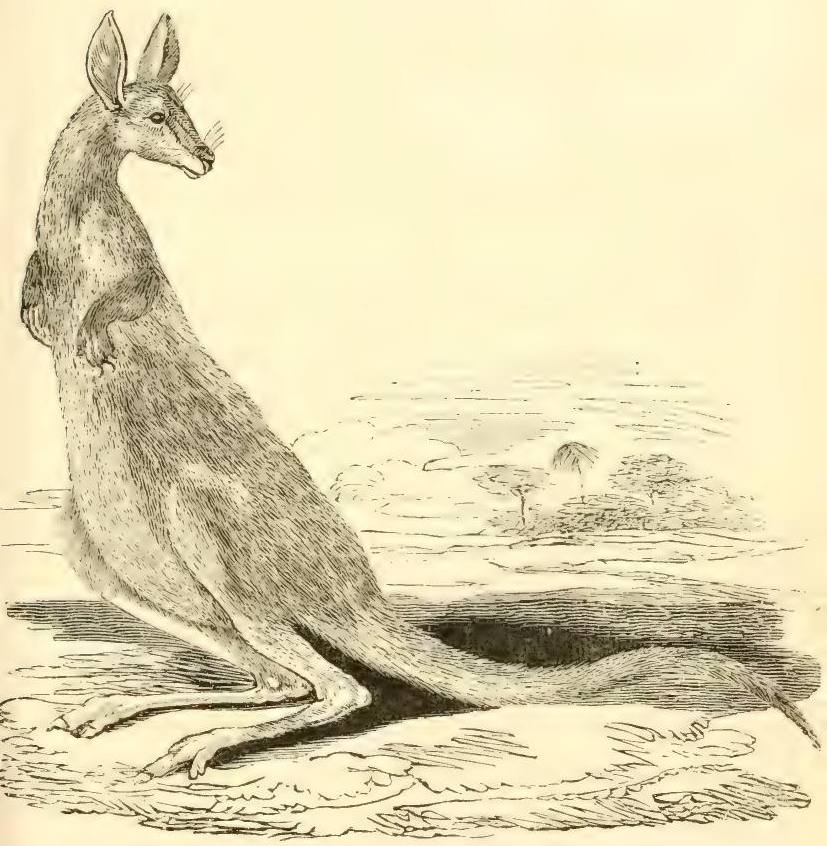

K ANGAROO.

Published by Marsh and Miller, Oxford-street, and Colnaghi, Cockspur-street. 

and fifty pounds, is the largest native animal either in New South Wales or in T'an Diemen's Land. It feeds on regetables, chiefly grass, and burrows in the ground; but comes abroad in troops of thirty or forty, upon which occasion, one of the party performs the duty of sentinel, after the manner of the Marmots. At present, wild Kangaroos are often seen feeding among the Cows of the English settlers. The Kangaroo moves by leaping, which it can do to the length of twenty feet, clearing obstacles of nine feet in height; and is thus enabled to elude the pursuit of even the swiftest Greyhound. The fore-legs are seldom more than nine inches long, while the hinder are about three feet and a-half. Its tail is a very powerful member, but not remarkable for its length.

The Jerboa is a rery small animal, of the Patel or Mouse kind, with a rery long tail, and a native of Asia, and Africa. The Siberian Jerboa has a body of the length of eight inches, with a tail of ten. In feeding and general habits of life it much resembles the Marmot. Its burrows are many yards long. 
and run oblique and winding, but not more than half-a-yard beneath the surface, ending in a large cavity. They have usually but one entrance; the animals work another passage, however, to within a very small distance from the surface; so that, in case of danger, they can cut it quickly through, and so escape!

The Kangaroo is sometimes thought to be a night animal; and the Jerboa, unlike the Marmot, comes abroad only at sun-set. In general, it stands or walks upon its hind-leg's; but, if surprised, it will sometimes go upon all fours, but soon recover its erect position. At the approach of danger it takes to fight, in leaps of six or seven feet high, repeating them so swiftly, that a man, mounted on a good horse, can scarcely orertake it. It does not proceed in a straight line, but jumps first to one side and then to the other, till it finds either its own burrow or some neighbouring one. When undisturbed, they stand erect, listen, and hop about like a Crow. In digging or eating, they drop, like the Kangaroo, on their fore-leg's ; but, in the latter action, they also often sit up like a squirrel. 



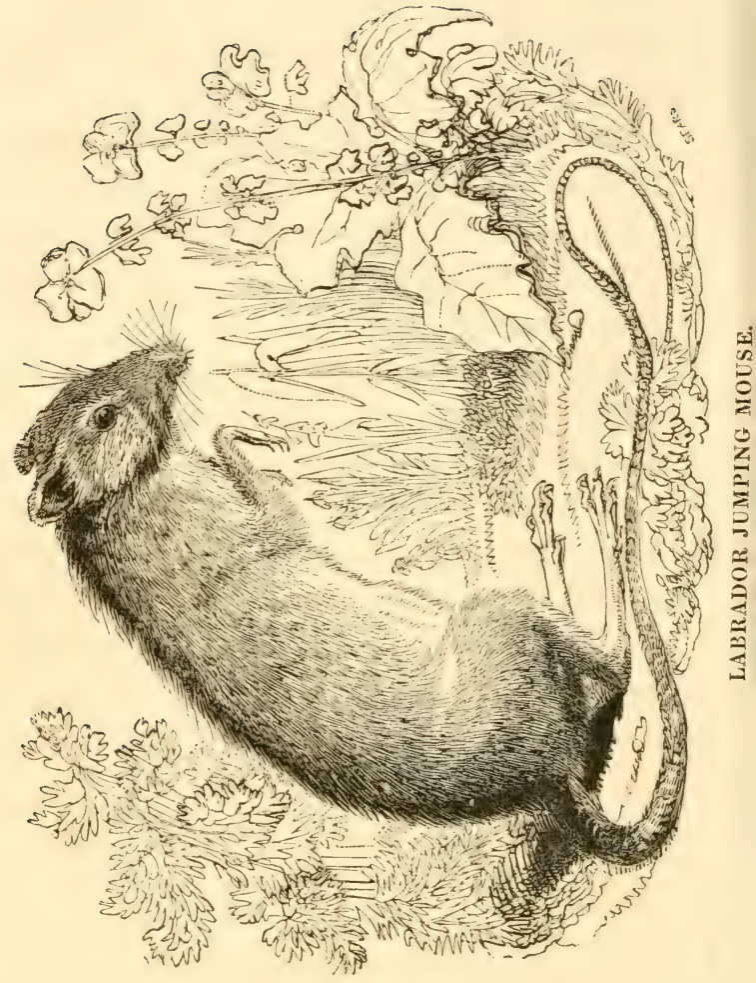


JERBOA.-LABRADOR MOUSE. 211

In confinement they are very susceptible of cold, and love to bask in the sum; and the moment they are put into the shade they cling close to each other.

The Labrador Jumping Mouse, varying, more or less, with climate and situation, is a very common animal in all the northern parts of North America. Its habits have been but little observed.

The colour of the Siberian Jerboa is a pale yellowish from above, and white beneath. That of the Labrador Jumping Nouse is a dark liver brown above, and white beneath ; but with sides of a brownish yellow, slightly sprinkled with black hairs. The Jerboas eat a variety of regetable food, but are particularly fond of tulip-roots. 


\section{ORIGINAL POETRY.}

\section{ECLOGUE I.}

\section{MORNING; OR, THE CAT'}

SLE, where the lovely Roneo lies,

In that sweet twilight of the mind

Which is, and yet is not;

$\mathrm{He}$ is not quite to sleep resign'd, For half he opes his blinking eyes,

To watch around the spot;

And see what soon may be his lot.

What makes him thus his vigils keep?

Why do his looks thus stray?

Why can't he from that half-glass door

Keep his sad eyes away?

And why can he not peaceful slecp,

Nor thus upon the future pore,

In thoughts sublime, that highly soar?

Visions of scraps, delicious bits

Of ham, or veal, or bread,

With broth, or milk, or coffee, mix'd,

Fly hovering round his head ;

And sweetly soothe him as he sits,

In pensive meditation fix'd

On cares that lie his hopes betwixt. 
But look! oh, look! the welcome sound! The door wide open flies;

"Romeo!" his mistress kindly calls, Joy sparkling in his eyes;

And, springing forth with many a bound, IIe comes, and on his breakfast falls, \ith appetite that never palls! 


\section{4}

MONKEY-CAGES, BABOONS, AND SATYRS.

INFINTE VARIETY OF THE MONKEY TRIBES.-BABOONS。

-SATYRS.-MAN-TIGERS.-APES. - CHIMPANZEE.ORAN-OTANG.

You are aware that the whole multitude of Monkeys, in which the tropical regions, throughout the globe, so much abound, is divided by Zoologists into three classes; those without tails, Apes; those with short tails, Baboons; and those with long tails, and small dimensions, Monkeys, especially so called. Of these, again, the first are animals generally reported as of a shy and serious deportment; the second, forward and ferocious; the third, cheerful, busy, sociable, and full of endless little diverting tricks, and of petty mischief, from perpetual motion and intermeddling. The diversity of form and colour, of figures and faces, which you witness here, will remind you of the di- 
versity, described as almost infinite, which subsists among the Monkey tribes, in their native situations.

"The varieties of the larger classes," says a writer, " are few ; in the Ape we have but four, and in the Baboon about as many. But when we come to the smaller class, the differences among them seem too tedious for enumeration: above fifty are found upon the Gold Coast alone. It is remarkable, that the Monkeys of two adjoining places are never found to mix with each other, but rigorously to observe a separation. Each forest contains only its own; and these guard their limits from the intrusion of all strangers of a different race from themselves."

With the most tenacious vigilance we might wonder, from this account, that the several species, intermingled in these Gardens, continue to live together so well as they do, were it not for the great changes in the manners of animals which attend either domestication or confinement.

The Baboons have been described as a large, fierce, and formidable race, which, mixing the figure of the man and the quad- 
ruped seems to possess only the inferior and less amiable qualities of both. They have in their respective species, the heads of Dogs, and of various other beasts; and the only real point of similitude to man is in the possession of hands. It deserves remark, that all the Monkey tribes, like man, are able to hold things with one hand, because they have thumbs; while many others, which can employ their fore-claws as hands, are obliged to use two, because thumbs are denied them. Baboons, as we have said, have tails, though short ones.

But, both to Baboons and Apes are sometimes given the name of Satyrs. The Satyr is a creation of mythology, and has no proper place in the catalogues of Zoology. Linnæus, however, has affixed the name of Simia Satyrus to the Oran-Otang, or Tree-pean, commonly called Wild Man of the Woods; and showmen, to attract the uninformed, are fond of describing the Mandril, or Rib-nosed Baboon, as a Satyr. To this latter animal is also sometimes given, with rather better reason, the name of Man-tegar, or Man-Tiger. None of the various means which have been 



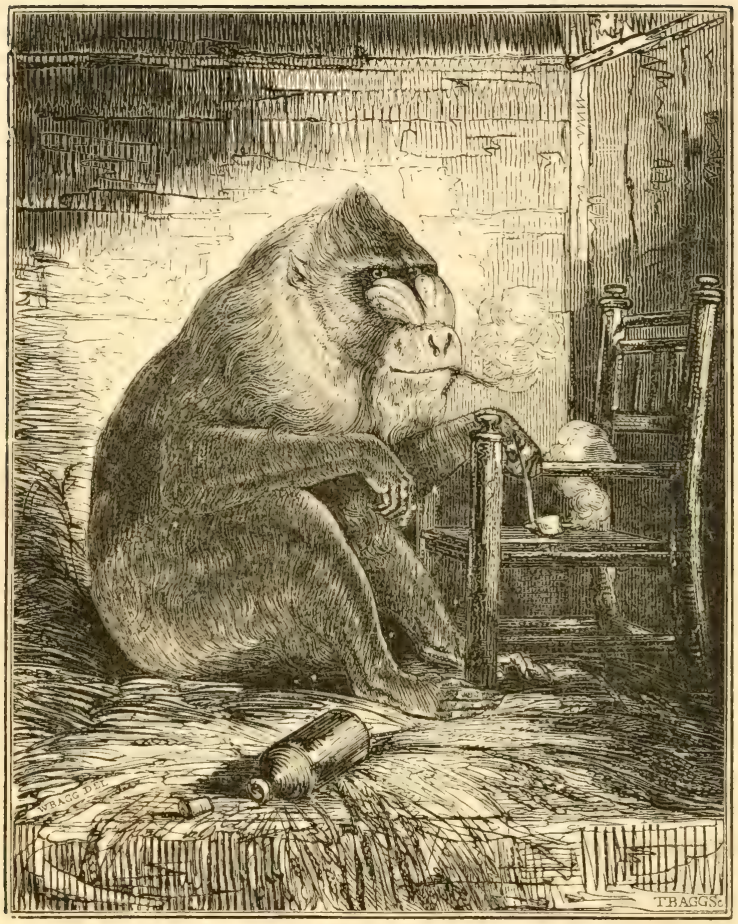

SA'I'YR.

Portrait of " Happy Jerry," at Cross's Menagerie.

Iublished by Marsh and Miller, Oxford-stret, and Colnaghi, Cockspur-street. 
adopted to subdue the ferocity of other beasts, have succeeded with this; and so superior in its strength to that of man, that the keepers of wild beasts uniformly hold it in dread. This, like all the other species of Monkey, lives, in a state of nature, entirely upon vegetable food. Under the name of Satyr, one of these very odious animals is at present exhibiting at Charing Cross; and after visiting these Gardens, you certainly, my dear Jane, would be interested there in observing this very sagacious animal sit on a chair, smoke a pipe, drink spirits and water, and appear fully to understand every look, word, and action of his keeper; indeed, so thoroughly contented is the creature, that he has obtained the name of "Happy Jerry." The Mandril, or Great Baboon, and the Mottled, or Common Baboon, are always irreclaimable wild beasts; but the Dog-faced species, is of a more tractable disposition.

Of the Ape, the two largest and most interesting species or varieties, are the Chimpanzee and the Oran-Otang, the first of which is found in Africa, and the second in India beyond the Ganges, and in the Eastern 
Islands; and almost all the stories which are isually told, as of the Great Indian or Asiatic Ape, properly pertains to the African Coasts.

The largest and most remarkable OranOtang which, as it is said, was ever seen by Europeans, was discovered and shot by an officer of the English ship, Mtary Anne Sophia, in the year 1824, at a place called Ramboon, near Toromon, on the west coast of the Island of Sumatra-a soil from which we have recently received so many Zoological novelties, especially through the active researches of Sir Stamford Raffles. When the officer I allude to first saw the animal, he assembled his people, and followed it to a tree, in a cultivated spot, in which it took refuge. Its walk was erect, but waddling, and not quick, and it was obliged to assist its motion occasionally with its hands; yet, by the help of a bough, or staff, with which it armed itself, it went forward with considerable rapidity. When it reached the tree, its strength displayed itself in a very high degree; for at one spring it gained a very lofty branch, and again bounded from it with 
all the ease of the smaller animals of its kind. Had the entire spot been covered with wood, it would certainly have escaped from its pursuers, for its mode of travelling by bough or tree was as rapid as the progress of a rery Heet horse; but, at Ramboon, only a few trees are left, in the midst of cultivated fields, and it was into that scany cover that the Oran-Otang jumped, to avoid being taken. He received the first shot in a tree, and when five balls had pierced him, and not before, his exertions were relaxed, in consequence, no doubt, of loss of blood. At the sime time, too, the ammunition of his pursuers being expended, other means only remained for ensuring its capture. One of the first balls probably penetrated its lungs; for, immediately after the infliction of the wound, it hung itsclf by its feet, from a branch, with its head downward, and allowed the blood to flow from its mouth. On receiving each fresh wound it put its hand over the injured part; and the human-like agony of its expression of the sense of pain, had the natural effect of moving the feelings of its assailants. The Sumatras of the place seemed as much sur- 
prised at the sight of the animal as the crew of the ship; for they had never seen an OranOtang before, though they lived within two days' journey of the Coast and unpenetrated forests of the interior. They set about to fell the tree upon which, in an exhausted state, it was now reclining; but the moment it found the tree unsteady, it put forth its remaining strength, and gained, first a second tree, and next a third, until it was finally brought to the ground, and forced into combat with its merciless foes, who now gathered quickly about it, and discharged spears and other missiles. The first spear, made of a very strong supple wood, which would have resisted the strength of the strongest man, broke into two, as if it had been a carrot; and had it not, now, been almost in a dying state, its assailants would have been in great peril of their lives. He fell, at length, under innumerable stabs inflicted by the people.

The Oran-Otang was supposed by those that killed it, to have travelled some distance to the place where it was found; for its legs were covered with mud up to the knees. Its hands and feet had great analogy to human hands and feet, only that the thumbs 
were smaller in proportion, and situated nearer to the wrist-joint. The body had fine human proportions ; a broad expanded chest, and a narrow waist; but its legs were rather short, and its arms very long, though both possessed such muscle and sinew as left no doubt of the strength of either. The head was in good proportion to the budy; and, as to the face, the nose was prominent, the eyes large, and the mouth larger than in man. Its chin was fringed, from the extremity of one ear to the other, with a shaggy beard, ending luxuriantly upon both sides, and forming, altogether, an ornamental, and not an ugly appearance to the face. When first killed, the hair of its coat was smooth and glossy; and its teeth, and whole appearance, showed that ic was young, and in full health and strength. Its stature was nearly eight feet.

It is thus reported by those who saw the animal alive; but even the measurement of the skin went far to determine that question. As to colour, the skin itself was a dark lead, and the hair, over the shoulder and flanks, was a brownish red. 


\section{LORD M- AND HIS BABOON.}

BY H. W. MONTAGU.

What! play me this ape's trick!-MarLow.

Is the year $17-$, Lord $M-$, then about twentyfive years of age, was married to the amiable and lovely Lady Louisa $\mathrm{F}$ - - : the match was contracted much against the will of his father, by reason of an antipathy which he seemed to have inherited towards the family; but his affection for an only son caused him to bear with this instance of disobedience, although some time elapsed before he became reconciled to his daughter-in-law.

My grandfather was a near relative of Lord $\mathrm{M}$ with which he professed to have been much amused, and which, I may, from my own experience, assert, that he was exceedingly fond of repeating.

I can, at this moment, fancy I see the excellenthearted old gentleman in his silk wrapper, slippers, and velvet cap, seated in an arm-chair, admirably constructed for luxurious ease, and preparing once more to tell me the story; but I will this time save him the trouble. 
By desire of her mother, the young lady visited Worcestershire, during the summer of the second year after her marriage, whither Lord XI-_, who was detained on some county affairs, was to follow her. In the interval, she wrote to him several times, but received no answer to her letters, until, at the end of some months, her mother, whose character was remarkable for haughtiness, wrote to him herself, requesting, without any explanation, that her daughter should thenceforth live separately from him. In the mean time, the father of Lord M- was glad of an opportunity to obstruct any conciliation, and counselled his son,-who was himself reserved, and resentful of slight,--not to make the first overture.

The youthful bride pined away for some months, and then seemed to resume a partial tranquillity; but this appearance was fallacious. Lord Msoon after the receipt of the letter from his motherin-law, bade adieu to his native country, and embarked for Flanders. For several months he had been observed to settle down into an air of the most unequivocal melancholy. He shunned every human face, contenting himself with its caricature in a favourite Baboon, named Irahmoud, a native of Prince Edward's Island, which he had purchased from an East India captain.

His father was so afflicted at his son's despondency as a sequence to this untoward alliance, that he sold the estate in Yorkshire, and took up his residence in Brighton; very occasionally visiting a considerable 


\section{LORD M- AND HIS BABOON.}

property entailed upon the latter in Gloucestershire. The Yorkshire estate fell into the hands of a near relative of Lady Louisa's mother, and by one of those coincidences which we sometimes observe and marvel at in human affairs, the young lady received an invitation to spend the summer of $17^{\text {*** }}$ there, with a view to the restoration of her health;-her mother was too well aware of a contrary result, and tried to dissuade her, but in vain, fiom accepting it;-the unhappy Louisa had reserved to herself but one hope in the desolateness of heart into which she had been plunged,-the hope to regain the scene of all her former hapyiness,-and to die there!

She had already spent a month in Yorkshire, when one evening she strolled to the foot of the lawn, and turned into a meadow, which she had often paced arm-in-arm with him, who was to her the principle of life and joy. The sun was setting in his calmest beauty; she could have wished her spirit at that moment as evanescent as his beams! But she was satisfied to know that ere long that desire would be accomplished. She had been for some time alone, but at length an old man with white hair, and leaning on a staff, approached her: notwithstanding his age, his eyes ran over with tear's as he contemplated her.

"Ans!" said he, "Lady Louisa has reason to weep, as well as the old man who ventures before her! Do not start," he continued ; " in me you will recollect the aged attendant on Lord $\mathrm{M}-$, whose 
fortunes I would fain have followed; but he repressed that wish, and journeyed despondent and solitary to the land of the stranger."

" Despondent!" echoed Lady Louisa.

"Yes," replied the old man; " the cause I only fancied. Young people do not always reflect before they act with coldness and indifference to each other." Lady Louisa sighed heavily. "If he be dead," said he,-

"Dead!" interrupted his auditress, almost gasping. "I fear," rejoined the old man-" I fear the worst." The young lady leant against a tree almost fainting. " IIeavens!" exclaimed the old servant, "what is that?"

Lady Louisa opened her eyes at the strangeness of this peroration, but had scarcely done so, when, running from the tree, she set up a scream so dreadful that it is impossible to give even a remote idea of it, and falling on the ground, the Baboon of Lord $M-$ was seen clinging to her and gnashing its teeth. Leaving her almost immediately, the animal hastened to the tree, and from a dry and hollow part of it, pulled out a large package of letters, which it kept turning orer as mechanically as a twopennypostman. Almost at the same moment Lord Mapproached; he raised the person who had fallen, and beheld-one whom he had watched for many day's without having decided to make himse!f known to her. We pass over the scene which followed, and which those who have been as attached as were 


\section{LORD M- $\triangle N$ IIIS BABOON}

they, will easily supply, and we hasten to the explanation.

Lord M- was in the habit of placing all his letters for Lady Louisa in a particular drawer in the hall, whence they were taken by his valet to the post-ofice at the neighbouring village. That this last personage had, on observing the usual supply of epistles to cease, thought the circumstance remarkable, was true, but then it was no business of his, and saved him a walk to which he was by no means partial. A being whom he personally resembled had exhibited a more active spirit, and had voluntarily taken the letters, which he had watched his master put into the drawer,-out of it,-and had conveyed them to a depôt of stolen articles near the foot of the meadow; of their safety, it would appear, notwithstanding the lapse of time and his continental travels, he was singularly jealous, if we may judge from his attack upon the privileged sex. Lord $\mathrm{N}$ - and his brirle perceived, with a rapidity which duller and less sublimated mortals can hardly conceive, the whole of the mystery; the letters were there and the delinquent also, who was impudent enough even to resist their delivery to the writer of them, and for which he would have been caned, but that the young laciy interfered. This last was in a short time restored to health and the bloom of beauty, and with the entire accordance of her mother and Lord M.'s father, was re-united to the husband of her choice-the enraptured Lord M- 
As a sort of retribution, MLuhmond was given away on the day of the discovery to Lord D-e, who finding his habits of petty-larceny continue inveterate, sent him to Polito's Menagerie, where he delighted the nation for some years, bequeathing the art of grinning, and other good qualities, to a son and grandson, the last of whom is living, and is at this moment exhibiting his very prepossessing countenance at the Zoological Gardens, in the Regent's Park.

My grandfather was frequently heard to remark, between the whiffs of a German-pipe, to which he was particularly attached, "that the tissue of events which governed the destinies of man, was, indeed, most strangely concatenated,'- (the surgeon of the neighbouring village drily remarked, that conmonkeynated would, in this case, have been a much better word,) "since," continued my grandfather " an insensible lump of mimickry,-a blue-faced baboon,-could create schism between a husband and wife of unparalleler constancy,-plunge them into the depths of melancholy disappointment, and bring them to within a few days of the grave." 


\section{8}

BRAHMIN BULL.

BRAHINEE BULL. - SMALL ZEBUS. - ANTELOPE. -

SAMBOO DEER. - REIN DEER, AND RED DEER.BLACK-TAILED DEER.

"That beautiful Brahmin, or Brahminee, Bull," said Mr. Dartmouth, " very strongly reminds me, as well by its countenance, its figure, the pink insides of its ears, and the prevailing whiteness of its coat, of the celebrated breed of Wild Cattle, as they are called, in Lord Tankerville's park, at Chillingham, in Northumberland. I am persuaded that those cattle are foreigners, and I could fancy them of the sacred breed in India, and perhaps in ancient Egypt. It is true that the Chillingham breed is wholly white; but its muzzle, like this of the Bull before us, is black. The Egyptian Apis was mottled white and black; and, if this Brahminee Bull can be of the kind which Egyptian history referred to, its identity would be interesting to our views of the 
Kigyptian and Hindoo faiths respectively; and ve might think it possible that the breed found its way into the north of Fngland at the time when the Fyyptian Isis had a temple in the city of lork, and was worshipped in Paris and Marseilles.

" The little Zebus, or Trebooes, are small varieties of their kind, and the larger ones, in the possession of the Society, are removed to the farm at Kingston. Tou may observe that these Zebus have the same black, or grey and white coat, and hump, as the Brahmin Bull; and that small as these Oxen are, they hare still the luroad nose, which, as well as their horns, distinguishes the race from both Deer and Antelopes. But let us cross the garden once more, and take another look at the Samboo, or Samboo Deer, from India, which seems a southern variety of the Elk; and when we get home, you shall read an interesting account of the Stags, or Red Deer, in Scotland, where they are still wild. As to the size and figure of the Stag, you may have seen that beautiful animal ; in many English parks it is kept in ¿ state half wild and half tame." 
"So we will read it, Uncle!" said Jane; " and I can tell you, here, some pretty lines, which I learned the other day, about the migration of troops of the Wild Deer, when winter comes on, and their numbers are too great, so that they can find but little to eat:-

' The genial years increase the timid herd,

Till wood and pasture yield a scant supply;

Then troop the Deer, as at a signal word,

And in long lines o'er barren downs they hie,

In search what food far valleys may supply.'"

The Black-tailed Deer, of which there is a specimen in the Museum, at Bruton-street, is a native of North America, where, along with another species, it is called Chevreuil, or Roe, by the French Canadians; and Jumping Deer, by the English of Hudson's Bay. It is found only to the Westward of $105^{\circ}$ west longitude, and goes no farther north than the banks of the river Sadcatchewan. When roused, this Deer makes off by a series of uninterrupted bounds, raising all its feet from the ground at once, and vibrating its black-tipped tail from side to side. The height of a full-grown Doe has been found to be rather less than two feet and a half. 



\section{1}

\section{ORIGINAL POE'TRY.}

\section{ECLOGUE III.}

\section{EVENING; OR, THE IIORSE.}

Now evening's dews begin to fall,

And clouds obscure the sky ;

The setting sun in glory sinks, -

Then, to the field I hie ;

And there on $J_{A C K}$ I loudly call,

He looks, and sees me, as he thinks,

With eyes as keen as any lynx:

He sees the treasure in my hand-

Potatoes, grain, or bread;

And neighs with pleasure, as he goes

(Tossing his high-raised head)

To reach the place he sees me stand.

No obstacles his way oppose ;

He comes-and 'gainst me rubs his nose ;

He every coaxing art employs,

To get his favourite root ;-

Potatoes, which he loves as much

As children can love fruit!

For this he every method tries;

Indeed, sometimes his airs are such,

That humble bread he scarce can touch ;

For $J_{\text {A }}$ K was bred in Erin's isle,

And loves potatoes well;

Like all green Erin's sons, the same,

Though here he 's forced to dwell;

And oftentimes he makes us smile

To see him thus his birth proclaim,

And plainly tell from whence he came. 


\section{MARMOTS.}

MARMOTS OF SWITZERLAND, TARTARY, AND RUSSIA, MARMOTS POM NORTI AMERICA.

THESE are a very numerous and very interesting group of animals, embracing from the Mouse upwards to the Bear, the whole of which, under a general view, have the same form and structure of body, the same descriptions of food, and the same manners, movements, and modes of life. All are more or less tractable and ingenious, and all provide themselves with nests. Most, if not the whole, sleep during the winter.

In the families of this attractive group, none are more pleasing in their appearance, nor more agreeable in their history. The Marmots are a race of fur-clad little animals, of about sixteen inches in length, allied, upon the one hand, to the Rat, and upon the other, to the Squirrel. The Marmots are the special inhabitants of countries cold mountainous, and wooded They bury them. 


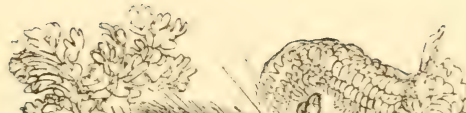

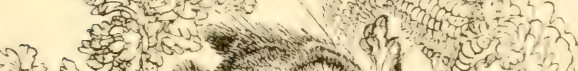

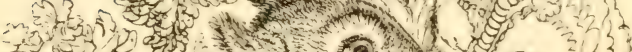

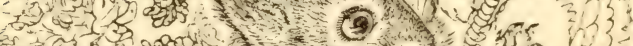

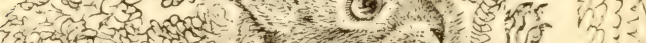

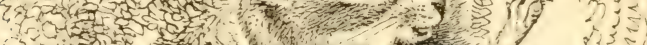
o

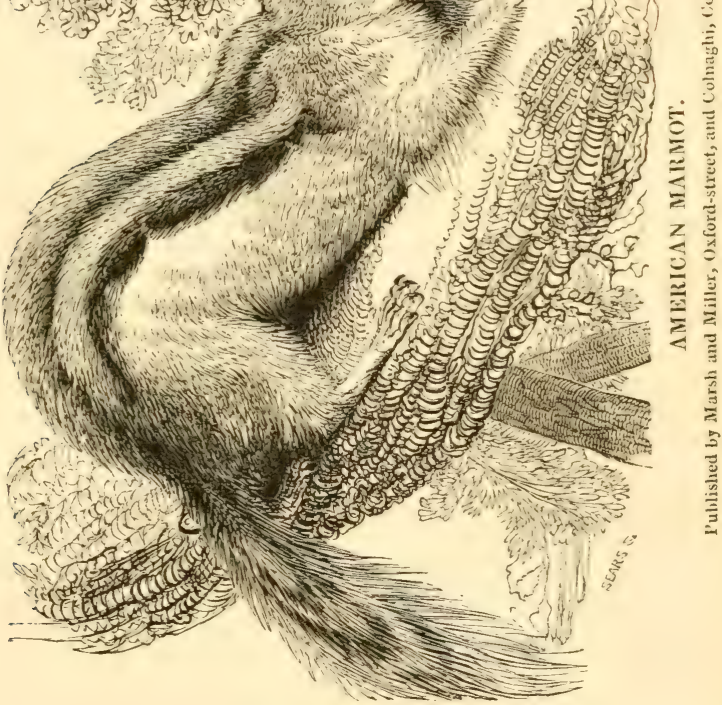



selves in cares, and feed upon nuts and seeds.

In Switzerland, the Marmots delight in the loftiest regions of frost and snow, and are seldom found on the plains, or in the open country. Their holes are constructed with much art, each forming a kind of gallery in the form of the letter $\mathrm{Y}$, with an aperture at each upper extremity, and terminating below in a capacious apartment, where several of the animals lodge together. The apartment is well lined with moss and hay, of which commodities they lay up great stores during the summer.

It is affirmed that the labour of collecting the materials for their nests is carried on by the animals in concert; that some of them cut the finest herbage; that others collect it together; and that they carry it home upon a cart, made of one of their companions for the occasion! The Marmot which performs the cart, lays himself down upon his back, extends his limbs, and allows himself to be loaded with hay; which done, others of the party trail him along by the tail, taking great care not to overset him ! The part of 
cart is taken in his turn by each of the performers. "I have seen them practise this mode of conveyance," says a French traveller in the Ukraine, "and have had the curiosity to watch them at it for several days successively." The dwellings which they construct and furnish with so much industry and care, are the places in which they pass three-fourths of their lives. Into these they retire from the rain, and from every approach of danger; and they never come abroad but in fine weather, and even then but to a short distance.

When out of their holes, one of the band stands sentinel, while the others play about, or cut grass for making hay. If the sentinel perceives a man, an eagle, a dog, or any dangerous living thing, he alarms his friends by a loud whistle, and is himself the last to enter the hole. They have a special fear or horror of the dog.

The Marmots leave their holes at break of day to feed; but do not bring out their young ones till the sun has risen. When they make their appearance, they frolic in every direction; ruis and leap after each 
other, or sit upright, facing the sun, with an air of satisfaction. They love warmth, and when they think themselves secure, will bask in the sun for hours successively.

The Marmot has a quick eye, and discovers an enemy at a considerable distance. He never does the least harm to any other animal; and when himself attacked, he attempts to escape. If flight is impossible, he defends himself with spirit, even against men and dogs. Marmots sit upright when they eat, and carry the food to their mouths with their fore-paws. When irritated, or when any one attempts to lay hold of them, they bite desperately and utter a shriil cry. They are mild, goocl-natured, and timid, and soon become tame, even if taken at full age. The young ones are familiar from the moment that they are caught, and may be easily domesticated. They will walk upon their hind-feet, sit upright, dance with a stick between their paws, and perform various other tricks taught them by their masters. Even in domestication, however, they will but eat little during the winter; and escape to some 
comfortable place, to give themselves up to sleep. In summer they eat voraciously; and, in a state of nature, are so fat, at the approach of the sleeping season, as often to weigh twenty pounds. In the northern latitudes, of which they are native, they retire to their holes about the end of September, and do not come abroad again before the beginning of April.

The elegant specimen represented" in the engraving, is a native of North America, and has on each of its sides a yellowish white stripe, bordered with black, while the general colour of its coat is grey. This species is very small, not exceeding nine inches in length, from the nose to the root of the tail; with a tail, in. cluding the fur, of not more than three inches. As farther illustrative of its real habits, I may add, that in countries where the rhubarb-plant is found, the Marmots are said usually to fix their residence near to them; and that if ten or twenty of those plants are growing adjacent to each other, several burrows of Marmots are always found immediately under the shode and protection of thcir leaves. Every animal has its own farourite vegetable. 


\section{ORIGINAI POETRY.}

\section{AN EPISTLE \\ FROM ROMEO TO MISS -}

By the hand of his Mistress.

Containing an account of an adventure he had met with, and of a visit which he had made to the parlour, at the request of two Gentlemen who were drinking tea with his aforesaid Mistress.

BY THE.AUTHOR OF "THE MUMMY."

Dear lady, I have dared to tread In the forbidden parlour's bounds; And Pнсве's broom, above my head,

No longer big with rengeance sounds! My heart still throhs whene'er I think On what, that day, I dared to do: Dear Mistress, take your pen and ink, And write as fast as I can mew !

Tell, how my hairs stood all on end, When the shut door with dread I view'd; Till you, most kindly, stood my friend, And all my trembling fears sublued : 
Tell, how you spread the genial board With tempting food, to win my stay; And to my heart you found a roadA road well known-" the milky way."

Now, by the stranger-guests carest,

I bent my head to meet each hand;

No more vain terrors fill'd my breast;-

Gently I purr'd in murmurs bland. But, soon the happy hour was past, The time was come I must retire; And for the howling wintry blast, Quit all the comforts of the fire!

I went, and though the night was chill,

IVith joyful heart I went away;

For, though I had been favour'd-still,

I felt I was constrain'd to stay.

Nor do I at my fate repine,

Nor wish to seek the house again;

For, now, dear liberty is mine-

Precious to Cats, as well as Men!

Romeo. 



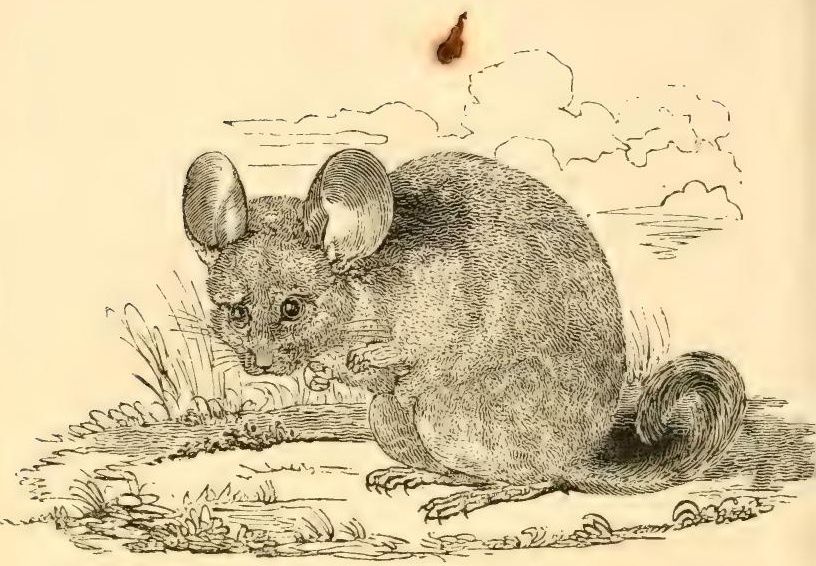

\section{Chincinten}

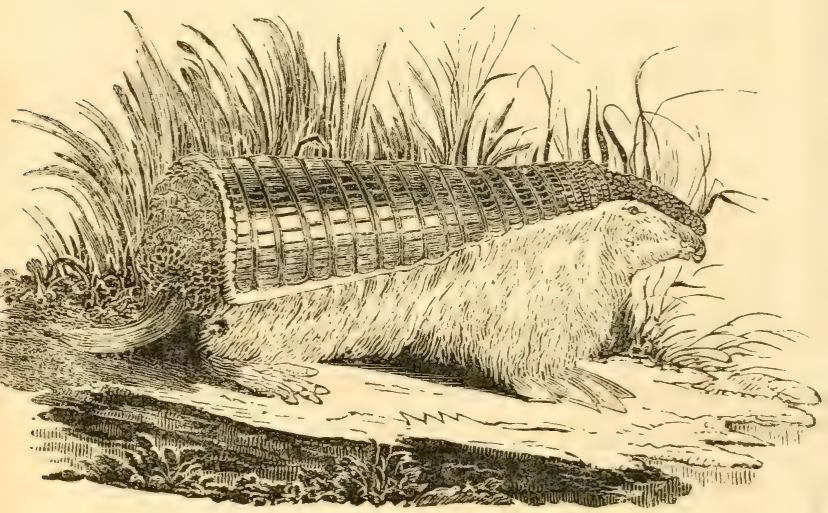

\section{CLAMYPHORUS.}

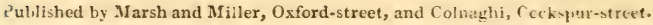




\section{CHINCHE, CHINCHILLA, AND CLAMY-} PHORUS, OR SHIELD-BEARER.

CLAMYPIORCS.-ARMADILLO. - MANIS. - MAMMA, IESEMBLING ALL TIIE SIX CLASSES OF AXIMALS; OR, BEASTS, BIRDS, FISHES, REPTILES, AND INSECTS.CHINCHILLA.-CHINCHE.-ARDILLA.-ARDA.

The Chinche, Chinchilla, the Clamyphorus, or Shield-bearer, of which two latter, if not of the Chinche also, there are specimens in the collection of the Society, are diminutive natives of South America, and all of them great novelties in the pages of natural history. The Clamyphorus, of which the Society has only a stuffed specimen and a skeleton, is of the Armadillo kind, and has been discovered only within the last two years. From the tip of the nose to the root of the tail, it measures but five inches and a quarter; its height at the shoulder is only one inch and three quarters; and the length of its tail is one inch. This is rather less than half the size of the Three-banded Ar- 
madillo. All the Armadillos are natives of South America, and are inoffensive animals, which burrow in the ground, and feed upon vegetables. Buffon speaks of an Armadillo which he saw in Languedoc, domesticated and going about the house without doing any mischief.

The Armadillos, with their shells upon their backs, remind us of the Tortoise, as the Manises, with their scales, remind us of the Lizards; and it even appears that nature, within the class Mammalia, or warmblooded and sucking animals, has a sort of imitation of all the classes of the animate creation together. Among the Mammalia, the great majority of the species are the Quadrupeds, or beasts commonly so called; but, in the same class, the Bats, the Flying Squirrel, and still more, the Ornithorynchus, or Platypus,* of New Holland, make ap-

* Specimens of the Five-toed, or Short-tailed Manis, which, by some writers, is called the Pangolin, and referred to the Island of Java for its country; and also of another, called Manis Javanica in the Catalogue, are to be seen in the Museum, Nos. 265,266 . 
proaches to the class of Birds; the Otter, the Beaver, the Hippopotamus, the Walrus, the Whale, and many others, to the class of Fishes; and the Armadilloes and Manises to the class of Reptiles, and in these to the class of insects; for the Insects and the Reptiles are closely united.**

The Chinchilla, kept in Bruton-street, and of which a representation is amexed, is the first specimen of that animal ever seen in Fugland, and perhaps in Europe, and was imported only last year. Before that time, too, the true description of the animal was almost wholly unknown, notwithstanding the myriads of Chinchilla skins which have fourd their way to Furope, as winter luxuries for the fair.

This snecimen of the Chinchilla, as recently described, is about nine inches in length, with a tail of nearly five. Its proportions are close set, and its limbs comparatively short; but the linder legs are considerably longer than those before. The fur is long, thick, close, woolly, somewhat crisp and entangled, grayish, oi ash-coloured

* Societi's Museum, Nos. 268, 270. 
above, and paler beneath. It lives in burrows, in the open country of the northern provinces of Chili, and is very fond of being in company with others of its species. It feeds upon various roots which grow abundantly in those parts; and produces, twice a year, five or six young ones. It is so docile, and mild in temper, that if taken into the hand, it neither bites nor tries to escape. If placed in the bosom, it remains there as still and quiet as if in its own nest. It is entirely free from that ill odour which characterizes the other species of Rats.

In the same collection is a second animal, presented by Lady Knighton ; it is larger in size, and rougher in its fur, than the Chinchilla; and its colour is less uniformly gray, the back and sides being mottled with numerous small blackish spots; it is much more cheerful and frolicsome than the Chinchilla.

The names Chinchilla and Ardilla are obviously Spanish diminutives, and imply that the animal to which they are given is smaller than some other with which it is compared. Molina speaks of the Harda, (otherwise Arda,) and may not this be Lady Knigh- 
ton's specimen? The author of the "Garden and Menageries" resents the notion of Buffon, that the Chinchilla is the same with the Chinche, another name occurring in South America, because, as he states, "the Chinche is the most insupportably offensive of all stinking animals; and because the skins of the Chinche and Chinchilla are essentially different, as may be seen in the warehouse of every furrier." That the writer now quoted has in view two really and very different animals of South America, sererally called Chinche and Chinchilla, there can be no reason to doubt; but is it equally certain that the name of Chinche may not have a looser and a more general interpretation in South America, and be really applied to what the Spaniards call Arda, or a Squirrel, and that this may be the larger species or variety presented by Lady Knighton, and native of the north of Chili and of Peru; while the smaller is the Chinchilla, or Ardilla, or Little Squirrel of the Spaniards; and with its smaller size, and, therefore, finer and warmer coat, a native of the more northern or colder parts of Chili? 


\section{AVIARY FOR SMALL BIRDS, AND CAGES FOR OWLS.}

CHINLE STARLING. - ENGLISH STARLINGS. - BATTLE OF IHE STARLINGS.-TIIE LOST STARLING.-BROWN STAILING.-OWLS.-RAVENS.-TWO RAVENS OF NIMEGLEN.-BLTTERFLY OWL.- IAWK OWL.- LITCH OWI.-TWO RAVENS OF MIDDLE, IN SHROPSHIRE.RAVEN AND DOG AT IEXGERFORD, IN WILTSHIRE. OTTEK, CAGE, AND POND.

A LL the buildings in the Zoological Garden reflect great credit upon the taste of Mr. Decimus Burton their designer: the Aviary for Small Birds is the most elegant, as well as most extensive of the whole. In passing the $I V$ estern division of that Aviary (appropriated to Foreign Birds) the beauty of the specimen of the female Crowned Partridge, from Sumatra, caught, as usual, the attention of the party; and the Chinese Starling reminded a friend who was with them, of an extraordinary battle, among two flocks of English Starlings, of which he had occasion to be witness. 


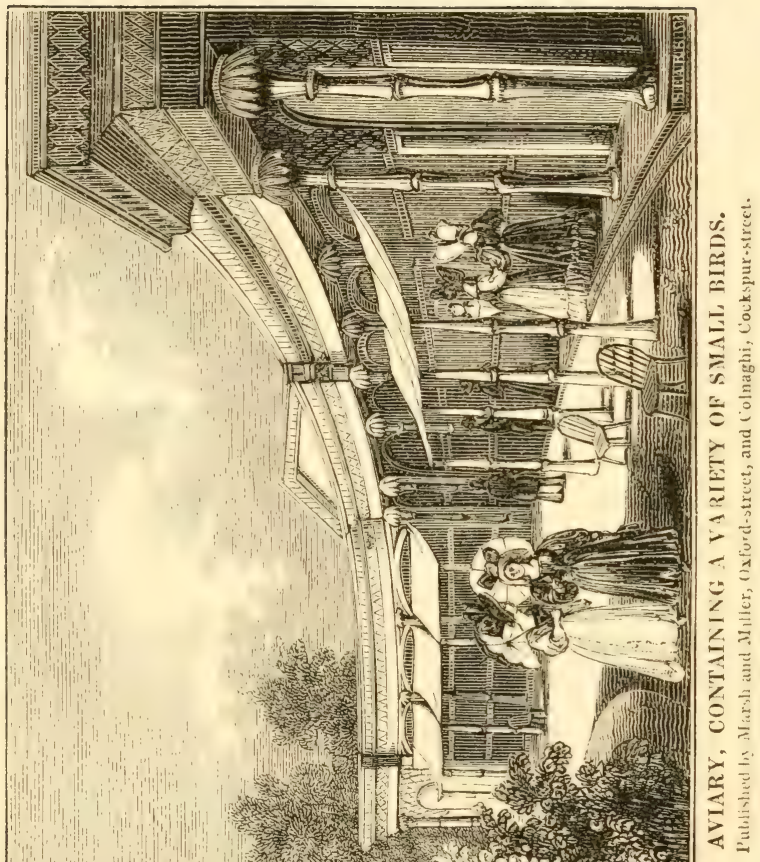



"6 One evening," said he, "when I was at a friend's house in Yorkshire, last autumn, there were such immense numbers of these birds, which had sought sustenance by day in the neighbouring marshes, and at night came to roost in his trees, that at length there was not room for the accommodation of the whole; and the consequence was, that it becane a matter of necessity that a separation should take place, a part going to other quarters, and a remainder lieeping possession. If I might judge, however, from the conflicting arguments which their confused chattering seemed to indicate, the decision was by no means relished by those whose lot it was to depart; nevertheless, a separation did take place, though the exiles did not go without maling trial of the fate of arms. Individual birds, like heralds in arnies, fiew here and there; unceasing roices gave drcadful note of preparation; and, at length, both sicles took flight at the same instant. The whirring sound of their united wings was perfectly dcafening; and, when both partics had attained a great height in the air, the two forces clashed together with 
the greatest impetuosity; and immediately, the sky was obscured with an appearance like the failing of snow, descending gradually to the earth, while great numbers of the bodies of Starlings, speared through by hostile beaks, literally fell like hail. It was growing dark at the time, and I could only see the contending flocks at a great distance above me; and, while the combat was still lasting, it grew darker, and I retired to the house. In the morning, in company with my friend, I visited the field of battle; and, together, we picked up, by careful enumeration, one thousand and eighty-seven birds, some quite dead, and others, for the most part, severely wounded; besides an amazing quantity of feathers.

"These Stores, or Starlings," continued the narrator, "were of the species called Common Starling, * of which we have many always resident in England; and which, from time to time, in great multitudes, from foreign countries, throng in upon us in autumn; and it was, no doubt, between two of these bands * Sturnus Vulgaris.-LinN. 
of mutual strangers, that my great battle was fought. The war must spring in the actual want of space for the two parties together; for there is no crcature which is more fond of numerous, and even mixed, society, than the Common Starling. Fiot only does it assemble in large flocks of its own species, and continually cluster upon all occasions, but it joins birds of many different linds, as the Redwing and Ficldfare, and even Owls, Jackiaws, and Pigeons. It is a bird of very interesting mamners, as well as rery beautifully feathered. The Brown Starling, or solitary Thrush, is a bird of very different habits from those of the former; though even this, in spite of its name, loves to be united in smali flocks."

"Oh!" cried Jane, "you say that the Starlings join with the Owls! So would I if they were all Butterfly Owls, like the little one, from Brazil, in the Museum. But let us look at the great $\mathrm{Owls}$, here, in the Garden. I wish there was a specimen of the Hawk Owl, from New Holland, which, they say, the natives talk to, and try to learn their 
fortunes from! Which is the Owl there is so much superstition about in our own country?

" The shrieking Litch $\mathrm{Owl}$, that does never cry, But boding death, and quick herself inters In darksome graves, and hollow scpulchres." "*

"That, I fancy, is any Owl ; unless, indeed, the Hawk Owl, if we had it in England ; for the Hawk Owl is a day-bird, and not a bird of darkness."

"But is there no Litch Owl, then?"

"Lich, or Litch Owl, is only the name given by superstition to any Owl. Its meaning is, Corpse Owl, or Dead Owl."

"It is in the same scnse of the word Litch, or Lich, that those picturesque porches, which we see adjoining tise yewtrees, in the walls of some of our country churchyards, are called Litch-gates, and the lanes leading to them, Litch-ways. The porches are designed for corerings under which the moumers at funerals may await the arrival of the clergyman. In the same way, too, the city of Litchfield receives its 
name, signifying Dead-field, or Corpse-field. It is the history, or tradition, that a Multitude of Christian proselytes wew killed and buried there, uncier the prsscution of a Roman governor :-

"A thousand chosen saints, whom Amphibel had taught,

Flying the Pagan fue, their lives that strictly sought, Trere slain where Litchfield is, whose name doth rightly sound,

There, of those Christians slain, Dead-field, or Burying-ground."

Drayton.

65 And does not the Raven share in the superstitions attached to the Owl :"

"Assuredly; and it owes this to its black colour, its feeding upon dead bodics, and its extraordinary instincts and sagacity. There is no part of the world in which the Raren has not taken a strong hold upon the imaginations of mankind, and has, in consequence, become an object of much attention, and often of marked regard and reneration. On the quay at Nimeguen, two ravens are now, or were formerly kept, in a roomy apartment, with a wooden cage in front, which served them for a balcony, and fed daily 
upon fine poultry; for the privileges of the city depend, or depended, by charter, upon the fulfilment of that condition. In the Manuscripts of the Rev. Mr. Gough, of Shrewsbury, it is related, that one Thomas Elkes, of Middle, in Shropshire, being guardian to his eldest brother's child, who was young, and stood in his way to a considerable estate, hired a poor boy to entice him into a corn-field to gather flowers, and meeting them, sent the poor boy home, and took his nephew in his arms, and carried him to a pond at the other end of the field, into which he threw the child, and there left it to die. The child being missed, and inquiry made, Elkes fled, and took the London road. The neighbours sent two horsemen in pursuit, who passing along the road near South Mims, in Hertfordshire, saw two Ravens sitting on a cock of hay, making an unusual noise, and pulling the hay about with their beaks; on which they went to the place, and found Elkes asleep under the hay, who said that those two Ravens had never left him from the time he committed the murder. He was carried back to Shrewsbury, tried, 
ELKES, THE MURDERER.-OTTER. 251

condemned, and hung in chains on Knockin Heath.

The foregoing is one of those traditions of which at least the tendency is salutary; and if, in truth, the murderer was not so much followed by the same identical Ravens, as led by a guilty conscience to see accusers and harbingers of justice in all the Ravens that he could have met with, from one end of the world to the other, still the moral is impressive.

"The Otter Cage," observed Mr. Dartmouth, on going by, " is empty; but it keeps in our remembrance that indefatigable consumer of fish. I must repeat, that I strongly desire to see the Bears, and especially the White Bear, in possession of a cage upon this model; but do you remember what a poet says of the Otter?

" 'Would you preserve a numerous finny lace, Let your fierce Dogs the ravenous Otter cliase; Th' amplibious monster ranges all the shores, Darts through the wares, and every haunt explores: $\mathrm{Or}$, let the gin his roving steps betray, And save from hostile jaws the scaly prey!" ", 


\section{IIOUSE AND CAGE FOR MACAIS.}

MACAWS, MOCK BIRDS.-NAME OITEN MIS-SPELT.TPIE PARROTS GENERALLY NATIVES OF AFRICA.CUCKATOOS AND LORIES, OF THE EAST INDIES.MACAWS OF SOU'JH AMERICA.-RED AND BLUE II $A \mathrm{CAW}$ - RED AND YELLOW MACAW.

Macaws (not Maccaws) are Mock-birds. The word Macaw, or Caw, is a derivation from Mock.

Macaws are a larger, but not less docile species of Parrot; and all the Parrots are natives of the Tropical regions, through several parts of which the different species are naturally spread. Generally speaking, the true Parrols belong to Africa; the Cockatoos and Lories, to India and the Indian, or Eastern Islands, down to Australia. Parrakeet, or Parroquets, are small species of Parrots; and there are small species of Macaws, called Parrakeet Macaws. 


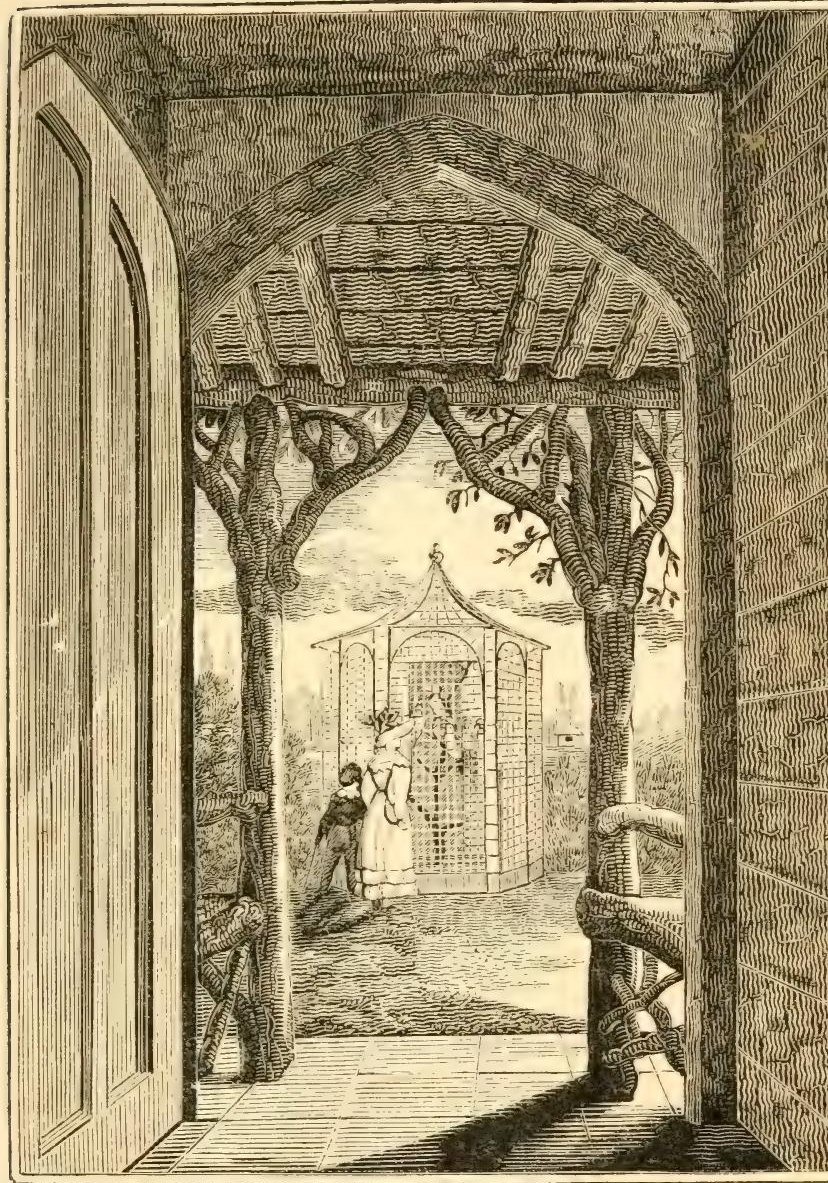

BEAUTIFUL VARIETY OF LARGE PARROTS, COCKATOOS, \&c. TAKEN FROM THE PASSAGE TO THE LLAMA HOUSE.

Published by Marsh and Miller, Oxford-street, and Colnaghi, Cockspur-street. 

In India and Africa, the Parrots, Cockatoos, and Lories; and in south America, the Macaws, share with Monkeys and Serpents the dominion of the forests, and mingle their screams with the screams and chattering of the former, and the hisses of the latter. In each of these three descriptions of animals, the numbers and the rariety are alike, and alike countless and indescribable.

These White Parrots (Lories) are seen in the buning regions of Ethiopia; in the East Indies, they are of the largest size; in south America, they are docile and talkative; in all the islands of the Pacific Sea and the Indian Occan, they swarm in great raricty and abundance, and add to the splendour of those woods which Nature has dressed in eternal green!

The beautiful House and Cage in the Zoological Garden, containing the rich assemblage of beautiful Nacaws, boasts as its most splendid specimen the whole, the Red and Blue Macaw, * a native of the Brazil and the West Indics, presented to the Society by the Domna Maria da Chloria, * Macrocercus Macao. 
the young Queen of Portugal: it is one of the largest and most highly ornamented of the species. It measures nearly three feet, from the top of the head to the extremity of the tail; and the latter, when in fine condition, is full two-thirds of the total length. The gerieral colour of its plumage is a deep and brilliant red, separated, on the intermediate wing-coverts, and behind the shoulders, from the deep and violet blue of the large quill feathers of the wings, by a broad band of bluish green. The tail is usually blue at the base, crimson at the middle, blue again at the extremity, and blood-red beneath; but all these colours vary both in intensity and extent.* It is peculiar to this species to have three or four transverse lines of minute clustered crimson feathers upon the cheeks, which latter, as well as the cere-covering of the base of the bill, are perfectly white.

The Red and Yellow Macaw, in the same Cage, is a smaller species. There are Cockatoos and Lories in the same Cage with the Macaws.

* See Garden and Menageries. 



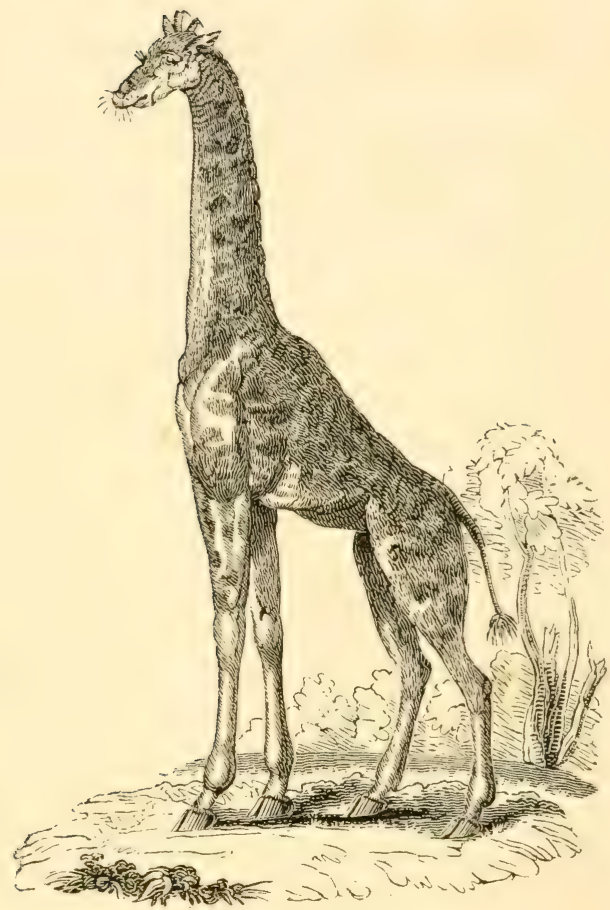

GIRAFFE.

"uhlished by Marsh and Miiler, Oxford-street, and Colnaghi, Cockspur=street. 


\section{GIRAFFE, OR CAMEL-OPARD.}

GIRAFF, A NATIVE OF THE SOUTH OF AFRICA.-RARITY OF TIE SPECIMENS IN EUROPF.-THE IIIG'S GIRAFFE AT WINDSOR, - ITS ARIIVAL, SICKNESS, AND DEATH.

THE Giraffe is one of those animals, singular either for form or other appearances, which distinguish the Zoology of the South of Africa. Giraffe, or Jariffe, * is the name given to it by the Arabs. By the Romans, from its figure upon one side, and from its spots upon the other, it was called Camelopardalis, or Camel-Leopard, Pard, or Panther. The Giraffe is not difficult to meet to the northward of the Cape of Good Hope. It lives upon regetable food, and is often the prey of the Lion, which springs upon its back, and holds it with his mouth and claws, while the animal runs for miles, carrying its destroyer upon its back, till, faint with fatigue and loss of blood, it falls down, and is deyoured.

After a lapse of thrce conturics, during all * Or Xariffa. 
which no living Giraffe had been brought into any part in leurope, the present active Pasha of Egypt, in which country the Giraffe sometimes arrives, as a rarity, from the more southern parts of Africa, suddenly sent forth four, as royal presents;-one to Constantinople; one to Venice; one to the King of France; and one to His Britannic Majesty. That sent to Constantinople died soon after its arrival; and that received in England, and kept, with the fullest care and attention, by His Majesty, at Windsor, died in the nonth of October last, after a length of infimity and sickness. It was young and small. It arived at Windsor on the 13th of August, $182 \%$.

Though the Giraffe has been commonly compared with the Camel, it is probably, except in size, more related to the Antelope. Its head, which, as observed by M. Le Taillant, is doubtles: the most beautiful part of its body, has nothing of the character of the Camel, but makes a far nearer approach to the head of the Antclope, or, perhaps, still nearer to that of the Horse. The spots upon its sides, and other particulars of its figure, should again remind us of the Antelope. 
The eye is deceived in supposing that the fore-logs of the Giratie are longer than those behind. The real difference is in the height of the shoulders, as compared with that of the haunches.

Besides the height of the shoulders, the peculiarity of this animal consists in the lengih of its nech, which it caries upright, and not incurvated, like the necks of the Camel and the Ostrich. An oid description of a (irafie, (or Jomufa,) reccired as a present in Armenia, asserts, that "From the hoof of the fore-leg to the top of the shoulder, it was sixtecn hands high; and from the shoulders to the head, sixtecu more."

such are the exagocration fornerly receires as to the size of the Giraffe. Buffon and Goldsmith speak of it as an animal so tall that ${ }^{66}$ a man on horseback could, with case, ricle under its belly without stooping; ;" and this account is attempted to be justified by the calculation, that " as these creatures have been found eighteen feet high, and ten from the top of the shoulder, so, allowing three feet for the depth of the body, seven fect remain, which is high enough to 
admit a man mounted mpon a middle-sized Horse!" The depth of the buty of the Giraffe, however, is proportionably greater, and therefore the space beneath the belly proportionably lower than in that estimate. Part of the dimensions of the Giraffe at IVindsor, when measured at its first arrival, were as follows :-

Length of the head, one fout nine inches.

From the top of the head to the bottom of the hoof, ten feet eight inches.

From the top of the head to the neck root, four feet.

From the neck root to the elhow, or diepth of the body at the shoulders, two feet three inches.

Thus leaving but four feet three inches, out of ten feet cight inches, the total height, for the space between the belly and the ground. Goldswith gives the following dimensions of the skin of a young Girafie, killed at the Cape of Good Hope :-

Length of the head, one foot eight inches.

Ieight from the shoulder to the top of the hear, seven feet

Height of the hind-legs to the top of the back, eight feet five inches.

Height of the fore-legs to the top of the shoulder, ten feet.

Length from the ting of the shoullex to the in sertion of the tail seren inches. 
The young Giraffe, at Windsor, was a female; and after growing eighteen inches from the time of its arrival, measured thirteen feet in all. When she first arrived, she was exceedingly playful, and perfectly harmless. Neither her figure nor her coat agreed exactly with the common descriptions; but this might happen because she was young and a female; and the spots appear always to differ in different varieties or ages, or with the sex. Her back was straight, or conrex, like the back of the Guanaco in the Zoological Garden, and therefore wholly without the deformity, or at least the singularity of the form, by which, still more than by any thing else, the Giraffe is distinguished from all other animals.

\section{BEAVER-HOUSE AND POND.}

BEAVERA IN AXCILNT DHITAIN-HEAVER-HOCSE IN THE ZOOIOGICAL GARLEAS.-HE.IYIR-HOUSES BLILT HY DEAVEIS. - TAME BEAVEIS. - IOUD OF BEAVERS.

Beavers, though now brought here from a distant country, were ancient inhabitants of these islands. Many historical traces of 
the Beaver are mentioned, from which it is known to have existed in Wales, and in the West of England; but, in truth, it was spread over the whole country. Beverley, the name of a town in Iorkshire, meant literally "Beaver-ley," or Beaver-meadow. By the Welsh, or ancient British, it was called " the beast with the broad tail."

The natural habits of the Benver are topies so generally, though often so imperfectly, handled, that $\mathbb{I}$ will rather speak at present of the manners which it has bcen found to display in a domestic state, and of one or two other particulars less familiar to your knowledge.

We have domesticated certain animals, and most of these only to a certain extent, and are therefore apt to fancy that those are the only animals suscentible of domestication, and that they surpass all others in sagacity and companionable affections. But there is a very long list indeed of animals, apparently the last to be thought of for domestication, but which, nevertheless, would please, and be pleased, if they, like others, lay in our bosoms, ate of our dish, and sat at our fire-sides, and 
that would make manifest their understanding, and more than answer our caresses. An example, (but only cne example in a hundred,) presents itself in the Beaver, whose habits in domesticity are pictured by a North American trader.

" I have kept several Beavers," says Hearne, " till they becane so domesticated as to answer to their name, and to follow those to whom they are accustomed, in the same manner as a Dog would do; and they were as much pleased at being fondled as any animal I ever saw. In cold weather they were kept in my own sitting-room, where they were the constant companions of the Indian women and children, and were so fond of their company, that when the Indians were absent for any considerable time, the Beavers discovered great signs of uneasiness; and, on their return, showed equal marks of pleasure, by fondling them, crawling into their laps, lying on their backs, sitting like a Squirrel, and beharing like children who see their parents but seldom. In general, during the winter, they lived on the same food as the women did, and were 
remarkably fond of rice and plum-pudding : they would eat partridges and fresh renison very freely, but I never tried them with fish, though I have heard that they will at times prey on them. In fact, there are few graminivorous animals that may not be brought to be carnivorous."

Of the things usually eaten by the Beaver, the same witer gives the following account: _"6 Their food consists of a large root, something resembling a cabbage-stalk, which grows at the bottom of the lakes and rivers. They also eat the bark of trees, particularly those of the poplar, birch, and willow; but the ice preventing them from getting to the land in the winter, they have not any bark to feed on in that season, except that of such sticks as they cut down in summer, and throw into the water opposite the doors of their houses : and as they generally eat a great deal, the roots above-mentioned constitute a principai part of their focd during the winter. In summer they vary their diet, by eating different kinds of herbage, and such berries as grow near their haunts." 


\section{AN ADDRESS}

TO

\section{THE OLD Y EAR.}

BY THE AUTHOR OF "THE MUMMY."

SHADE of departed jors! where is't thou 'rt flown? Borne on the winch, I hear thy hollow moan.

Say, does remorse in thy sad boson rise, That thus the blast comes loaded with thy sighs? Art thou lamenting for the young and brave, Gay at thy dawn, now mouldering in the grave? Or dost thou grieve to find thy reign is o'er, And thou must fly as years have fled before? O'er thee Oblivion spreads her gloomy pall, And thou must share the common fate of all.As spirits ranish at the break of day, When morning dawns, thy being falles away; Thy infant offispring breaking through the gloom, Springs like a Phonix from its parent's tomb :Another day !-another year is born !Another monent from the future torn !

New prospects rise, and Nature seems to bring, E'en to the mind, a renovated $S_{\text {pring }}$; 'The sun of Hope shines brightening o'er our lot, And all our former sorrows are forgot; Year after year, time cheats us as it flies, And fairy visions dance before our eyes ; $\mathrm{lill}$, when at last, life linger's to its close, And we-amongst the former dead repose ; Fading like thee, our very names shall die, And buried 'midst the dust of ages lie. The light of Virtue, glistening through the gloom, Alone shall shed a halo round the tomb! 


\section{NEW LIBRARY, \\ MARSH AND MILLER,}

137, OXFORD-STREET.

In soliciting the attention of the Nobility and Gentry to the terms of their New Purlic Library, Marsh and Mrleer deem it essential to mention that their Subseribers may rely on an IMMEDIATE and I'NLIMTED supply of ALL NEWV PUBLICATIONS.

\section{CLASS I.}

The Year, 5l. 5s.; the Half-year, 3l. 3s.; the Quarter, 1l. 16s. Subscribers to this Class are entitled to 24 Volumes in the Country, or 12 Volumes in Town.

\section{CLASS II.}

The Year, $4 l .4 s$. ; the Half-year, $2 l .12 s .6 d$; the Quarter, 1l. 1ls, Gd. Subscribers to this Class are entitled to 16 Volumes in the Cointry, or 8 Volumes in Town.

\section{THE SUBSCRIPTION READING ROONS}

Are amply supplied with all the Horning and Evening lewspapers, New Publications, Reviews, Magazines, \&c. \&c. ant an excellent REFEREXCE LIBRARY. - Subscription, 3l. 3s. per annum.

\section{NEW WORKS,}

\section{PUBLISHED BY MARSII AND MILLER.}

THE PARLIAMENTARY POCKET'BOOK, for 1830. Dedicated to the Right Hon, the Speater of the Honse of Commons. 1 vol. 12 mo. nearly ready.

THE LITERARI BLUE-BOOK; or, KALFNDAR of LITER.ITLRE and the ARTS for 1330: containing, with their Name's and Addresses-

Eminent Living Authors-Painters-Sculptors-Architects-Engravers - Musical Composers-Musical Performers-meachers of Languages, de.

THE NEW CHESTEREIELD. 1 vol. 18 mo.

THE IVINE-DRINKERS' MANUAL.-Contents : History, Manufacture, and Management of Spanish, French, Rhenish, Italian, Madeira, Cape, and British Wines, and Viscellaneons Information, peculiarly acceptable to the Bon Vivant. 1 vol. $12 \mathrm{mo}$.

'THE COFFEE-DRINKERS' MIN I $\$ L, with the French Method of making Coffee, \&c. ; with an Engraving, price 2s.

THE ATHENAID; or, IHODERN GRECIANS. A Poem. 8vo.

\section{CHRISTMAS PRESENT,}

Price One Shilling, uniform with Hood's Epping Hunt,

\section{CRUIKSHANK'S MONSIEUR 'TONSON ;}

Illustrated by Engravings from R. Cruikshaul, by Branston and Whight, Slader, and Bonner. 






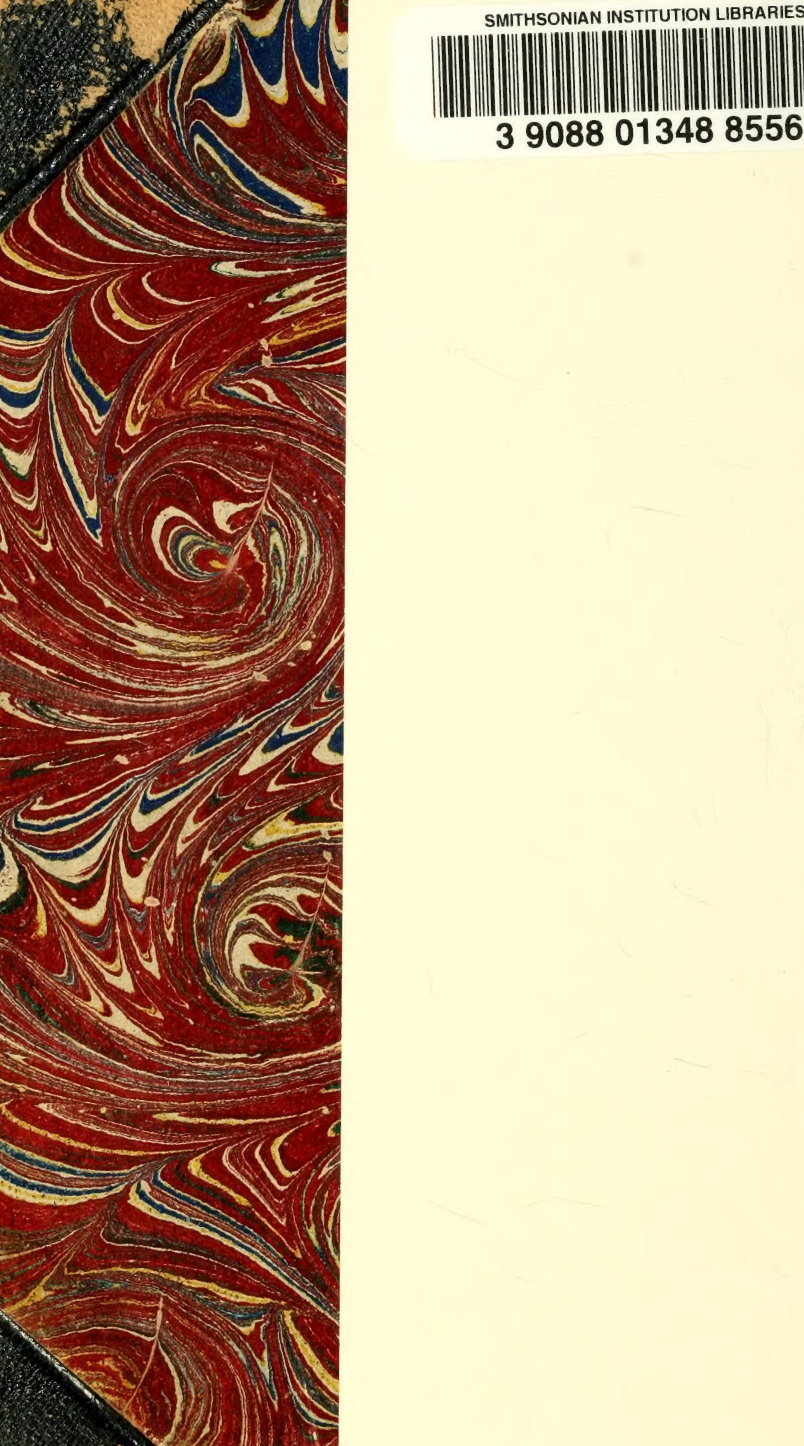